DIW BERLIN

Discussion

Papers
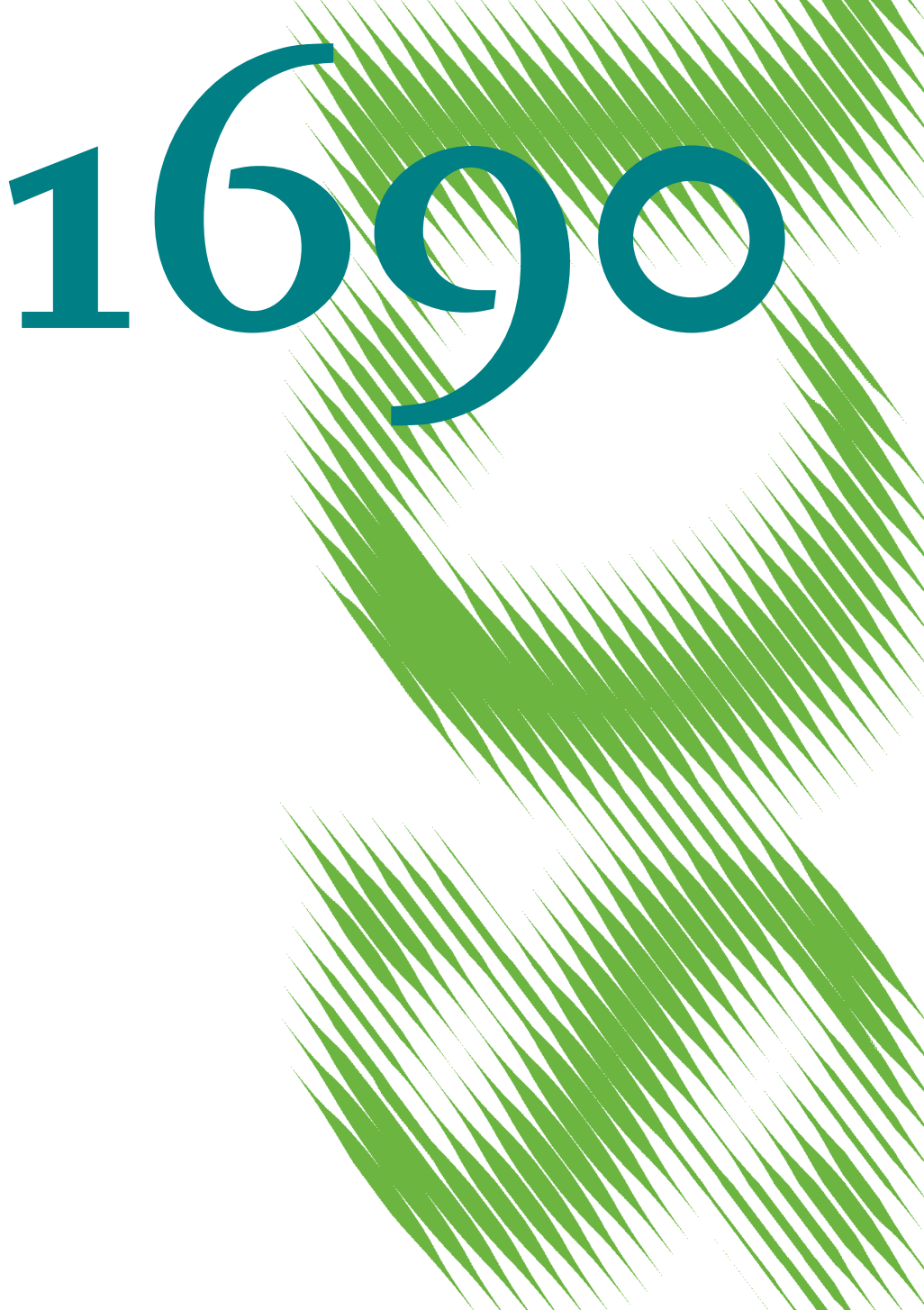

MMI

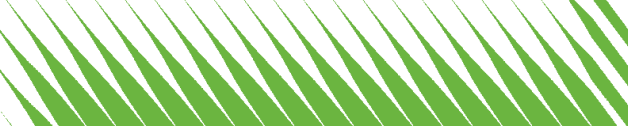

Hydrothermal Carbonization (HTC) of Green Waste: An Environmental and Economic Assessment of HTC Coal in the Metropolitan Region of Berlin, Germany 
Opinions expressed in this paper are those of the author(s) and do not necessarily reflect views of the institute.

IMPRESSUM

(C) DIW Berlin, 2017

DIW Berlin

German Institute for Economic Research

Mohrenstr. 58

10117 Berlin

Tel. +49 (30) $89789-0$

Fax +49 (30) $89789-200$

http://www.diw.de

ISSN electronic edition 1619-4535

Papers can be downloaded free of charge from the DIW Berlin website:

http://www.diw.de/discussionpapers

Discussion Papers of DIW Berlin are indexed in RePEc and SSRN:

http://ideas.repec.org/s/diw/diwwpp.html

http://www.ssrn.com/link/DIW-Berlin-German-Inst-Econ-Res.html 


\title{
Hydrothermal Carbonization (HTC) of Green Waste: An Environmental and Economic Assessment of HTC Coal in the Metropolitan Region of Berlin, Germany
}

\author{
Jakob Medick ${ }^{1}$ \\ Isabel Teichmann ${ }^{2}$ \\ Claudia Kemfert ${ }^{3}$
}

September 2017

\begin{abstract}
Based on a life-cycle sustainability assessment and the calculation of carbon abatement costs, we quantify the greenhouse-gas emission reductions and costs if green waste in the metropolitan region of Berlin, Germany, is diverted from composting into the production of hydrothermally carbonized coal (HTC coal) that is used as a substitute for hard coal in the generation of electricity and heat. Depending on the geographical origin of the green waste, we specify an urban scenario, a rural-urban scenario, and a rural scenario. Approximately 302 kilogram $(\mathrm{kg})$ of carbon-dioxide equivalents $\left(\mathrm{CO}_{2} \mathrm{e}\right)$ can be saved per megagram $(\mathrm{Mg})$ of fresh-matter $(\mathrm{FM})$ input in the urban scenario, $298 \mathrm{~kg} \mathrm{CO}_{2} \mathrm{e} / \mathrm{Mg} \mathrm{FM}$ input in the rural-urban scenario, and $316 \mathrm{~kg}$ $\mathrm{CO}_{2} \mathrm{e} / \mathrm{Mg} \mathrm{FM}$ input in the rural scenario. All three scenarios combined can mitigate a total of $70,511 \mathrm{Mg} \mathrm{CO} 2 \mathrm{e}$ per year. This corresponds to about $1.6 \%$ of Berlin's annual greenhouse-gas reduction targets over the 2005-2020 period. If only private costs are considered, the HTC scenarios are less profitable than their reference cases. However, the inclusion of emissionrelated damage costs has the potential to render them socially preferable. The respective thresholds for social desirability coincide with the carbon abatement costs, about $163 € / \mathrm{Mg}$ $\mathrm{CO}_{2} \mathrm{e}$ in the urban scenario, $74 € / \mathrm{Mg} \mathrm{CO}_{2} \mathrm{e}$ in the rural-urban scenario, and $75 € / \mathrm{Mg} \mathrm{CO}_{2} \mathrm{e}$ in the rural scenario. The lower abatement costs in the latter two scenarios are due to HTC-coal co-firing in an existing power plant rather than mono-firing it in a newly built biomass power plant. This shows that a comparatively favorable use of HTC coal might be as a bridging technology.
\end{abstract}

\section{JEL Classification: Q42; Q51; Q54}

Keywords: Hydrothermal carbonization; char; biocoal; climate change; renewable energy; biomass; waste management; life cycle

\footnotetext{
${ }^{1}$ Corresponding author, e-mail: medick@dwr-eco.com

${ }^{2}$ German Institute for Economic Research (DIW Berlin), e-mail: iteichmann@diw.de

${ }^{3}$ German Institute for Economic Research (DIW Berlin) and Hertie School of Governance (HSoG), e-mail: ckemfert@diw.de
} 


\section{1) Introduction}

The German government aims to cut the country's annual greenhouse-gas (GHG) emissions by $40 \%$ by $2020,55 \%$ by $2030,70 \%$ by 2040 , and $80-95 \%$ by 2050 , relative to the 1990 level (BMWi and BMU 2010). One of the main mechanisms to reach these targets is to substitute fossil fuels with renewable sources of energy, such as wind, solar energy, and biomass. In the power sector, for example, Germany has the objective to raise the share of renewable energy sources in gross electricity consumption to $40-45 \%$ by $2025,55-60 \%$ by 2035 , and at least $80 \%$ by 2050 (§ 1 EEG 2017 as published in Bundesgesetzblatt 2016). ${ }^{4}$ However, Germany largely relies on fluctuating renewables, especially wind and photovoltaics (Neuhoff et al. 2016). ${ }^{5}$ In order to deal with the fluctuations in supply and the weak correlation between supply and hourly load profiles, the integration of wind and photovoltaics into the power system requires numerous adaptation measures, including energy storage, demand management, network expansion, and flexible thermal back-up plants (cf. Schill 2014). In contrast, biomass has the advantage of being dispatchable (Neuhoff et al. 2016). Thus, it can contribute to reduced powerstorage requirements and system costs in a renewables-dominated electricity-generation system (Schill and Zerrahn 2017). In other words, despite of having a smaller potential as a renewable power source in Germany than wind or photovoltaics, biomass has highly attractive attributes. ${ }^{6}$

However, biomass is a controversial source of energy. The debate about energy crops and their role in food security and emissions from land-use change (e.g., Rosegrant and Msangi 2014; Searchinger et al. 2009) has strengthened the focus on biowaste, such as municipal green waste, for energy generation. In the search for efficient conversion technologies for such feedstocks (often characterized by high water contents, low heating values, and heterogeneous feedstock quality), hydrothermal carbonization (HTC) is discussed as a promising technology (e.g., Titirici et al. 2007; Funke and Ziegler 2010; Libra et al. 2011). HTC produces a solid, coal-like fuel, the so-called HTC coal, biocoal, or hydrochar, which can be used for stationary combustion. In this study, we assess the GHG mitigation potential and economic viability of HTC coal derived from herbaceous green waste (leaves and grass cuttings) in the metropolitan region of Berlin, Germany.

HTC was first described by Bergius (1913). It is a thermochemical conversion process that takes place in pressurized water and an inert atmosphere, typically at temperatures up to $180-280^{\circ} \mathrm{C}$, with processing times ranging from a few minutes to several hours (Libra et al. 2011: Table 1; Reza et al. 2014: 11-12). The process transforms biomass into a carbon-rich solid product, HTC coal, with some gaseous and liquid by-products. The mass yield of HTC coal is usually $50-80 \%$ of the initial biomass (by dry weight), while a share of $5-20 \%$ of the initial dry-weight biomass is transformed into liquids (total organic carbon dissolved in process water) and 2-5\% into gases, mainly carbon dioxide $\left(\mathrm{CO}_{2}\right)$ (Libra et al. 2011: Table 1). As illustrated by Reza et al. (2014: Table 1) for hardwood, softwood, grass, and agricultural residue, HTC coal has a higher carbon content (48-72\%) than the initial biomass $(45-55 \%){ }^{7}$ Correspondingly, the higher heating value (HHV) of HTC coal exceeds that of the biomass 19-29 megajoule per kilogram (MJ/kg), on a dry ash-free basis, versus $15-22 \mathrm{MJ} / \mathrm{kg}$ (Reza et al. 2014: Table 1). Moreover, it is similar to the HHV of lignite, $25 \mathrm{MJ} / \mathrm{kg}$ on a dry ash-free

\footnotetext{
${ }^{4}$ EEG refers to Erneuerbare-Energien-Gesetz, Germany's Renewable Energy Act.

${ }^{5}$ In 2016, renewables-based electricity generation in Germany was divided as follows: wind energy (41.1\%), photovoltaics (20.3\%), biomass (27.4\%), and hydropower (11.2\%) (Federal Ministry for Economic Affairs and Energy 2017).

${ }^{6}$ Moreover, biomass is the predominant renewable energy source in the German heat and transport sectors (Federal Ministry for Economic Affairs and Energy 2017).

${ }^{7}$ On average, $70 \%$ of the biomass carbon is recovered in the HTC coal (Ramke et al. 2012: 479); however, with huge variations depending on the type of feedstock (Ramke et al. 2012: Table 2).
} 
basis (Reza et al. 2014: Table 1). In many respects, HTC coal chemically resembles natural coal. For example, the hydrogen/carbon and oxygen/carbon ratios of HTC coal tend to be relatively close to those of lignite and may even reach those of sub-bituminous coal (Funke and Ziegler 2010; Berge et al. 2011; Ramke et al. 2012; Oliveira et al. 2013).

As HTC coal has a similar chemical structure as natural coal, it can be co-fired in conventional coal power plants. Moreover, it can be mono-fired in combined-heat-and-power (CHP) biomass plants. ${ }^{8}$ Other than direct biomass combustion and pyrolysis, ${ }^{9}$ HTC typically requires biomass with a water content of $75-90 \%$ (Libra et al. 2011: 98). Thus, it can process wet feedstocks without energy-intensive pre-drying. This increases the range of feedstocks potentially eligible for use as solid fuels to moist organic waste, such as sewage sludge, wet animal manures, and organic municipal solid waste (cf. Libra et al. 2011). ${ }^{10}$ Moreover, HTC coal tends to be more favorable for combustion than raw biomass due to reduced slagging and fouling (Reza et al. 2014) as well as increased maximum weight loss rates, higher ignition temperatures, and elevated combustion temperature regions (e.g., Liu et al. 2013). As a more homogenous solid fuel with a higher energy density, HTC coal is also easier to handle than the raw biomass during transport, storage, and combustion. Finally, for certain wet feedstocks, HTC can be even more suitable for energy recovery than anaerobic digestion. The anaerobic digestion of leaves, for example, yields only a very low amount of methane $\left(\mathrm{CH}_{4}\right)$, in the range of 15-25 cubic meters $\left(\mathrm{m}^{3}\right)$ per megagram $(\mathrm{Mg})$ of fresh-matter (FM) input (ICU 2011: 14). While associated with higher yields of $90 \mathrm{~m}^{3} \mathrm{CH}_{4} / \mathrm{Mg}$ FM input (ICU 2011: 14), the utilization of grass cuttings for anaerobic digestion, in turn, might involve technical difficulties, such as increased abrasion, increased stirring requirements, and frequent removals of sediment (Prochnow et al. 2009). ${ }^{11}$

Being readily available to replace fossil coal in conventional power plants, HTC coal has another advantage in that it can serve as a bridging technology to facilitate a gradual and orderly fossil-fuel phase-out. That is, existing coal-fired power plants can continue their operations, perhaps with some retrofitting, while substituting out a highly emission-intensive fossil fuel. However, the question is whether this is worthwhile from an economic point of view.

Against this background, we provide a case study for the use of HTC coal as a source of renewable energy in the metropolitan region of Berlin, Germany, comprising the Berlin city districts as well as some rural areas in the federal state of Brandenburg, southwest of Berlin. For three scenarios that are not mutually exclusive, it presents the technical GHG mitigation potential and an economic assessment of pulverized HTC coal from leaves and grass cuttings. The scenarios are differentiated by the geographical origin of the green waste (urban, ruralurban, and rural). Consequently, they also differ by the location of the HTC plant (urban location in the first two scenarios; rural location in the last), by the organization of the supply chain (including the ownership structure along the chain and the logistics concept for biomass transportation and storage), by the feedstock composition (mixture of urban leaves, urban grass

\footnotetext{
${ }^{8}$ Alternatively, HTC coal could be used as a soil amendment in agriculture to improve soil fertility and to sequester carbon in soils (e.g., Titirici et al. 2007; Libra et al. 2011; Reza et al. 2014); however, with mixed results (e.g., Reibe et al. 2015; Sänger et al. 2017). For other material uses, see Libra et al. (2011) and Reza et al. (2014).

${ }^{9}$ Pyrolysis is another carbonization process yielding a solid char product. Unlike HTC, however, it runs without water, heating the biomass in the (near) absence of oxygen. Moreover, pyrolysis proceeds at higher temperatures and leads to lower char yields (e.g., Libra et al. 2011: Table 1).

${ }^{10} \mathrm{HTC}$ coal can be mechanically dewatered relatively easily before it is further dried (e.g., Ramke et al. 2012).

${ }^{11}$ However, HTC has also some drawbacks. In particular, the HTC process water contains a vast amount of dissolved organic (and inorganic) compounds (e.g., Funke and Ziegler 2010). This decreases the efficiency of the HTC process since the carbon dissolved in the water cannot be used for energy generation - unless the HTC process water is recirculated to increase the carbon and energy yields of HTC coal (e.g., Stemann, Putschew, and Ziegler 2013) or anaerobically digested to produce biogas (e.g., Wirth et al. 2012). Whether recirculated/ anaerobically digested or not, the remaining HTC process water must undergo further treatment activities (e.g., Stemann, Putschew, and Ziegler 2013; Wirth et al. 2012).
} 
cuttings, and rural grass cuttings) and corresponding amount of biomass inputs necessary to target a common HTC-plant capacity, as well as by the site and mode for HTC-coal combustion (HTC-coal mono-firing in a new biomass CHP plant in the urban HTC scenario; HTC-coal cofiring in an existing CHP plant in the rural-urban and rural HTC scenarios). The green waste for HTC is diverted from composting, the current dominating conventional organic-wastemanagement system in and around Berlin, and the subsequent soil application of the compost to replace mineral fertilizers. The HTC coal is used for electricity and heat generation, substituting for hard coal. ${ }^{12}$

While we provide a case study for a relatively narrow region, our approach serves to embed the HTC scenarios in a realistic setting, considering local peculiarities that would otherwise be abstracted from. In particular, the HTC scenarios are tailored to existing actors in the region's waste-management and energy sectors. For the location of the HTC plants and the logistics concepts for biomass transportation and storage, we further take account of existing infrastructure that can be utilized under the HTC system. In the urban scenario, for example, the HTC plant is built at the site of a waste-incineration plant so that the electricity it generates can be used in the HTC process. Moreover, the HTC coal in this scenario is mono-fired in a biomass CHP plant built on-site, eliminating the need for its transport. The same holds in the rural-urban scenario, where the HTC facility is located at the site of the CHP plant where the HTC coal is co-fired. In this way, the HTC process can use electricity supplied by the CHP plant and no transport of HTC coal occurs. Already familiar with biomass handling, existing composting facilities and recycling points serve as sites for biomass preparation and storage. In the rural scenario, a composting facility is even used for HTC-coal production. Furthermore, we consider existing constraints that can be large cost drivers, such as the lack of large-scale inner-city storage space for biomass in the urban and rural-urban scenarios. Finally, our data for the HTC process refer to an industrial-scale demonstration plant developed by SunCoal Industries GmbH (SunCoal), a manufacturer of HTC systems in Ludwigsfelde, Brandenburg.

The technical GHG mitigation potential of HTC coal is obtained from a traditional lifecycle assessment (LCA). For the cost calculation, we use a life-cycle-costing (LCC) approach, a social life-cycle assessment (SLCA), and further derive the carbon abatement costs of HTC coal. Thus, the economic assessment is provided from the perspective of both private and public decision makers.

In terms of the LCA, we find that the redirection of green waste from composting to HTC and the substitution of hard coal by HTC coal can save $301.6 \mathrm{~kg}$ carbon-dioxide equivalents $\left(\mathrm{CO}_{2} \mathrm{e}\right)$ per $\mathrm{Mg}$ FM input in the urban scenario, $298.0 \mathrm{~kg} \mathrm{CO} 2 \mathrm{e} / \mathrm{Mg} \mathrm{FM}$ input in the rural-urban scenario, and $316.5 \mathrm{~kg} \mathrm{CO}_{2} \mathrm{e} / \mathrm{Mg} \mathrm{FM}$ input in the rural scenario. While the emission reductions are largely driven by the substitution of fossil coal, the variations between the scenarios are mainly due to different amounts of biomass inputs, feedstock compositions, and logistics concepts. Converting 73,701 Mg FM input into HTC coal in each year (a), the urban scenario has the potential to mitigate $22,230 \mathrm{Mg} \mathrm{CO}_{2} \mathrm{e} / \mathrm{a}$. Based on biomass inputs of 75,621 Mg FM/a and $81,361 \mathrm{Mg} \mathrm{FM} / \mathrm{a}$, the rural-urban and rural scenarios can mitigate $22,532 \mathrm{Mg} \mathrm{CO}_{2} \mathrm{e} / \mathrm{a}$ and $25,749 \mathrm{Mg} \mathrm{CO} 2 \mathrm{e} / \mathrm{a}$, respectively. Thus, the total GHG mitigation potential of HTC coal in the metropolitan region of Berlin amounts to $70,511 \mathrm{Mg} \mathrm{CO}_{2} \mathrm{e} / \mathrm{a}$.

Given its positive GHG mitigation potential, is HTC-coal production and combustion capable of competing economically with composting and hard-coal combustion? Just focusing on private (or direct, internal) costs, as done in the LCC approach, the answer is no. Not one of the HTC scenarios is associated with a greater net present value (NPV) than its respective reference scenario if only private costs are considered - be it along the entire cradle-to-grave

${ }^{12}$ In 2013, 50.5\% of Berlin's electricity was provided by hard coal; $7.5 \%$ by lignite (Amt für Statistik BerlinBrandenburg 2016: Table 3.6). The respective numbers for district heat were 23.6\% and 16.7\% (Amt für Statistik Berlin-Brandenburg 2016: Table 3.9). 
life cycle or from the more narrow perspective of the investor into the HTC facility. However, this outcome might change if social (or indirect, external) costs are taken into account. In particular, the relative profitability of the HTC scenarios depends strongly on the social costs of carbon, i.e. the assumed damage costs of GHG emissions. From the SLCA, where we apply damage costs of $70 € / \mathrm{Mg} \mathrm{CO}_{2} \mathrm{e}$, we obtain that the HTC scenarios still cannot compete with their reference scenarios. However, from our abatement-cost calculation, we can deduct that already a slight increase in the damage costs to $75 € / \mathrm{Mg} \mathrm{CO}_{2} \mathrm{e}$ would render the rural-urban and rural HTC scenarios superior to their respective reference cases. More precisely, we calculate abatement costs of $162.7 € / \mathrm{Mg} \mathrm{CO}_{2} \mathrm{e}$ in the urban scenario, $74.1 € / \mathrm{Mg} \mathrm{CO}_{2} \mathrm{e}$ in the rural-urban scenario, and $75.2 € / \mathrm{Mg} \mathrm{CO}_{2} \mathrm{e}$ in the rural scenario. The rural-urban and rural scenarios fare better in terms of abatement costs than the urban scenario mainly because they assume HTCcoal co-firing in an existing CHP plant rather than HTC-coal mono-firing in a CHP plant that is newly built. Moreover, they are associated with simpler logistics concepts.

Our analysis contributes to the environmental and economic literature on HTC coal. In particular, economic studies for HTC coal are still rare and largely rely on simulations of industrial-scale HTC plants derived from laboratory-scale data (e.g., Eberhardt et al. 2011; Erlach et al. 2011; Wirth et al. 2012; Stemann, Erlach, and Ziegler 2013). Among these studies, Eberhardt et al. (2011) develop a linear optimization model in which they derive the optimal size, number, and location of HTC plants in the federal state of Brandenburg, Germany. Thus, they are geographically the closest to our study. At "current" $\mathrm{CO}_{2}$ prices, i.e. without reflecting the social costs of carbon, the literature finds that HTC coal cannot compete with fossil coal (e.g., Eberhardt et al. 2011; Erlach et al. 2011; Stemann, Erlach, and Ziegler 2013), ${ }^{13}$ which our results confirm. Generally, the production costs of HTC coal strongly depend on feedstock costs, poplar wood chips accounting for 32-50\% of the total annual costs in Erlach et al. (2011) and cereal straw for about $50 \%$ of the total costs in Eberhardt et al. (2011). These results are not directly comparable to our study, however, since the green waste we consider has to be collected and disposed of in any case. Moreover, the respective biomass collection points earn tipping fees for the management of the green waste. Based on the calculations by Wirth et al. (2012), the costs of producing HTC coal could be possibly reduced by the anaerobic digestion of the HTC process water and the use of the resulting biogas as auxiliary energy in the HTC process if the wastewater degradation rates and the organic loading rates are high. Similarly, Erlach et al. (2011) find that the production costs of HTC coal derived from poplar wood chips can be reduced slightly if the HTP plant is integrated with a wood-fired CHP plant. Our urban and rural-urban HTC scenarios incorporate similar synergy effects with a waste-incineration plant and a CHP plant, respectively.

The remainder of the paper is organized as follows: Section 2 provides the methodology, and Section 3 contains a detailed account of the data. In Section 4, we present and discuss the results. Finally, Section 5 concludes and derives our policy implications.

\section{2) Methodology}

We provide an evaluation of HTC coal under three HTC scenarios in the metropolitan region of Berlin, Germany, with each scenario covering an industrial-scale HTC project. The metropolitan region of Berlin, as defined in our case study, comprises all Berlin city districts plus the adjacent rural counties of Brandenburg/Havel, Havelland, Potsdam, PotsdamMittelmark, and Teltow-Fläming, located in the federal state of Brandenburg, southwest of

\footnotetext{
${ }^{13}$ However, the production costs of HTC-coal pellets are comparable to those of wood pellets if biodegradable waste is available at zero cost (Erlach et al. 2011; Stemann, Erlach, and Ziegler 2013).
} 
Berlin. As input material into the HTC process, we focus on leaves and grass cuttings, i.e. herbaceous green waste. In the Berlin city districts, these types of organic municipal solid waste are collected and disposed of by the public waste-management company Berliner Stadtreinigung $(B S R)$, by parks departments, as well as by private gardening and landscaping firms. In the rural areas outside Berlin, municipal green-waste collection points are responsible for their collection and disposal. Currently, most leaves and grass cuttings are composted. However, it is planned to divert them away from composting in order to recover their energy value (Schwilling et al. 2011). Thus, the leaves and grass cuttings may become available for HTC, which appears to be better suited for the conversion of green waste than direct biomass burning, pyrolysis, or - at least for leaves - anaerobic digestion (see the Introduction).

As detailed in Section 2.1, the three HTC scenarios (or HTC projects) draw on different biomass resources and are, thus, not mutually exclusive. In other words, all three HTC scenarios can be realized simultaneously. Each HTC scenario's reference case corresponds to feedstock composting (plus soil application of the compost to substitute for mineral fertilizers) and energy generation from hard coal. The life-cycle stages and system boundaries for both the HTC and reference scenarios are presented in Section 2.2. To obtain most realistic outcomes, the different scenarios refer to existing infrastructure of green-waste collection points, composting facilities, and power plants.

To integrate environmental, economic, and social concerns in our analysis, the evaluation of the three HTC scenarios is based on a life-cycle sustainability assessment (Section 2.3) and the calculation of carbon abatement costs (Section 2.4). The life-cycle sustainability assessment consists of a traditional environmental life-cycle assessment (LCA), a life-cycle-costing (LCC) approach, and a social life-cycle assessment (SLCA) (Kloepffer 2008; Valdivia et al. 2012). Carbon abatement costs, in turn, refer to the costs to mitigate one unit of $\mathrm{CO}_{2} \mathrm{e}$.

\section{1) Scenarios}

For the design of the HTC scenarios, we assume that each HTC plant has an annual throughput of 55,000 $\mathrm{Mg}$ prepared and purified FM input ( $\left.\mathrm{FM}_{\text {prep }}\right)$. This capacity corresponds to the approximate scale of the HTC demonstration plant developed by SunCoal (SunCoal 2012: 3), which serves as reference plant for this study. Since leaves and grass cuttings contain a relatively high proportion of inorganic material (e.g., stones, plastics, glass, and sand), an initial FM input of up to 82,000 Mg is needed to obtain 55,000 Mg FM prep (cf. SunCoal 2012: 3). In other words, the amount of initial FM inputs in each of the three HTC scenarios is targeted to the capacity of 55,000 Mg FM prep/a.

As detailed in Table 1 (see the Appendix), the technical biomass potentials of Berlin's metropolitan region provide sufficient green waste to fully utilize the capacities of all the three HTC plants. ${ }^{14}$ In particular, the technical biomass potential of leaves and grass cuttings in the Berlin city districts amounts to $120,609 \mathrm{Mg} \mathrm{FM} / \mathrm{a}$, consisting of 72,251 Mg FM/a leaves from roads and yards, plus 48,358 Mg FM/a grass cuttings from roadside greenery, lawns, and biotope areas. Another 143,381 Mg FM/a of grass cuttings from yards, industrial sites, public green areas, roadsides, rivers, and the like could be obtained from the rural areas southwest of Berlin. Accordingly, we assume that the urban and rural feedstock potentials each fully serve one HTC facility, while the remaining urban and rural feedstock potentials combined satisfy the demand of the third HTC plant. Thus, the three scenarios are differentiated by the

\footnotetext{
${ }^{14}$ The term technical refers to the biomass potentials that are obtained when certain technological restrictions are applied to the maximally possible - theoretical - potentials (i.e. those that are only limited by laws of nature), without taking into account any economic considerations - which, in turn, would lead to so-called economic potentials (cf. Slade et al. 2011).
} 
geographical origin of the feedstocks, resulting in an urban HTC scenario, a rural-urban HTC scenario, and a rural HTC scenario. Correcting for the unused biomass potentials that exceed the initial FM inputs required for the targeted capacity of 55,000 Mg FM $\mathrm{Frep} / \mathrm{a}$ in each scenario, the final allocation of the feedstocks to the three HTC projects is shown in the second-last column of Table 1.

\subsection{1) Urban HTC Scenario}

In the urban HTC scenario, the HTC plant is established in the city of Berlin and fed solely with the urban feedstocks that are collected by $B S R$, the public waste-management company, and the parks departments. The precise $B S R$ collections that enter our analysis consist of $32,253 \mathrm{Mg}$ FM/a loose leaves from roads, $15,855 \mathrm{Mg} \mathrm{FM} / \mathrm{a}$ yard leaves from $B S R$ leaf sacks, and another $4,758 \mathrm{Mg} \mathrm{FM} / \mathrm{a}$ grass cuttings from roadside greenery (Table 1 and the sources cited therein). From the feedstock collections of the parks departments, we further use 6,695 Mg FM/a leaves and $14,140 \mathrm{Mg} \mathrm{FM} / \mathrm{a}$ grass cuttings (Table 1). Thus, the total biomass input into the urban HTC scenario amounts to $73,701 \mathrm{Mg}$ FM/a (Table 1).

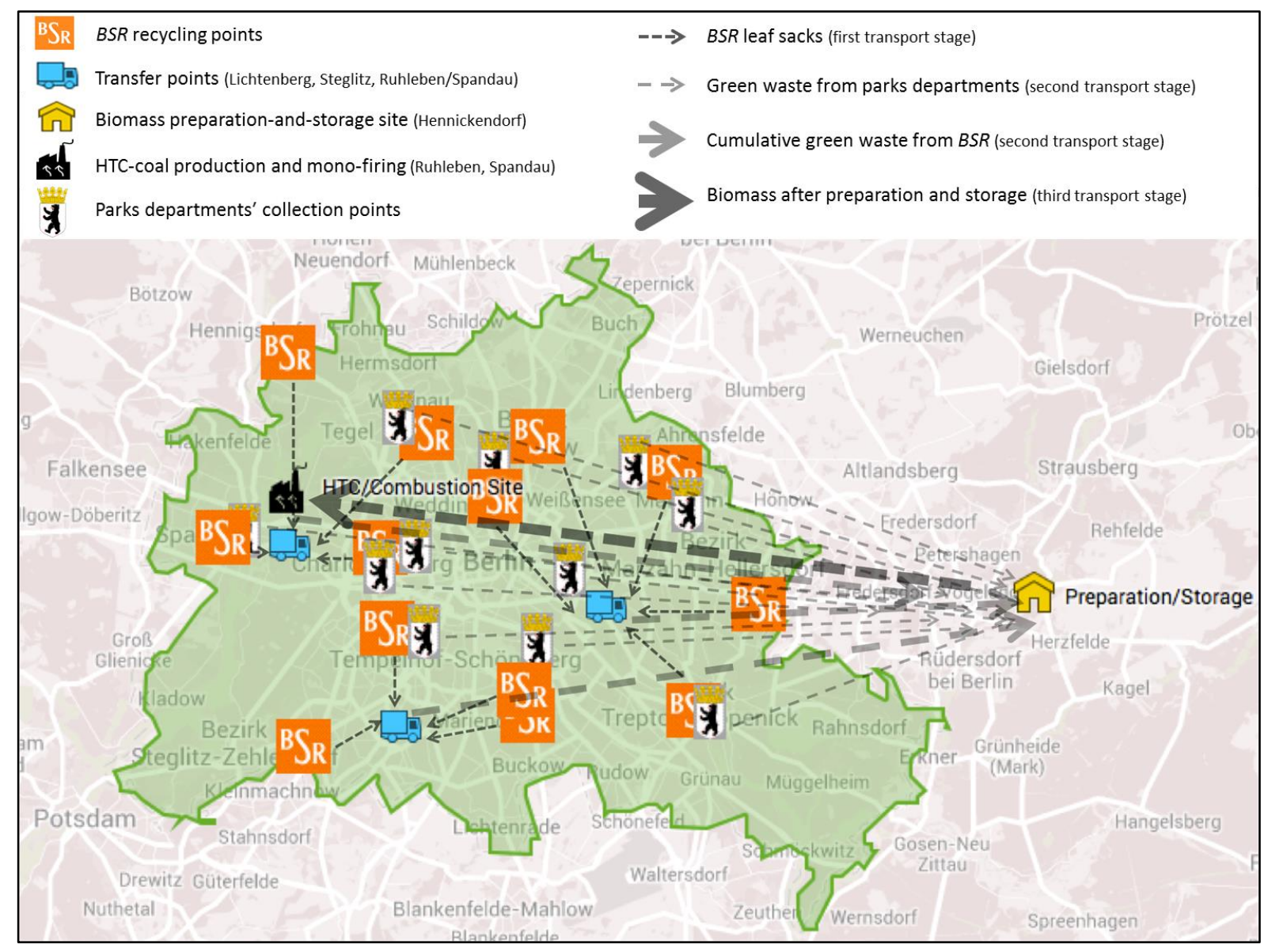

Figure 1: Logistics Concept of the Urban HTC Scenario

Source: Own illustration, based on Google Maps.

Managing the largest share of the urban feedstocks, the assumed owner and operator of the HTC plant is the BSR waste-management company. Moreover, we assume that the HTC plant 
is located at the site of an existing inner-city waste-incineration plant (Ruhleben, Spandau district) owned by $B S R$ (Figure 1). In this way, the electricity provided by the waste-incineration plant can be used in the HTC process, increasing the efficiency of HTC-coal production.

For the transport-cost assessment, we assume that the leaves collected through the BSR leaf-sack system are dropped off in equal proportions at each of the $16 \mathrm{BSR}$ recycling points located across Berlin (Figure 1). From there, they are transported (first transport stage) to three $B S R$ recycling points in the Berlin city districts of Lichtenberg, Steglitz, and Spandau (Ruhleben), which serve as biomass transfer points. Since the three transfer points form part of the $16 B S R$ recycling points, no transports occur for those leaf sacks already collected at the transfer points. Concerning the loose leaves and grass cuttings managed by $B S R$, we assume that they are directly collected by the three transfer points, again in equal proportions. The spatial distribution of the leaves and grass cuttings collected by the parks departments, in turn, is detailed in ICU (2011: Table 7). Due to the seasonal rhythms of vegetation - grass cuttings usually occur from April to October, while $95 \%$ of the leaves fall between October and January (Vogt et al. 2012) -, the input material has to be stored to enable a constant supply for the HTC plant. Therefore, all feedstocks from the three BSR transfer points and the parks departments are further transported (second transport stage) outside Berlin, to the site of a large composting facility in Hennickendorf, which is co-used as the central location for biomass preparation and storage. Since approximately one hectare of land is required for biomass storage (Vogt et al. 2012), this site is chosen due to the lack of storage space at the inner-city HTC plant and due to a general lack of urban storage space. From Hennickendorf, the prepared feedstocks are transported (third transport stage) to the HTC plant in Spandau (Ruhleben) for conversion into HTC coal. Finally, the HTC coal, in pulverized form, is mono-fired in a biomass CHP plant located on-site and newly built by BSR. To be consistent with the following HTC scenarios, we assume that the HTC coal substitutes for hard-coal combustion at an existing inner-city coalfired power plant, the Reuter West CHP plant, that is owned and operated by the energy company Vattenfall GmbH.

\subsection{2) Rural-Urban HTC Scenario}

While the rural-urban HTC scenario also assumes that the HTC plant is built directly in the city of Berlin, it draws on both urban and rural feedstocks. In particular, it uses 9,829 Mg FM/a of the urban leaves and $14,162 \mathrm{Mg}$ FM/a of the urban grass cuttings collected by the private gardening and landscaping firms in Berlin, and 51,629 Mg FM/a of the rural grass cuttings collected in Brandenburg/Havel, Havelland, and Potsdam (Table 1). The feedstock total entering the rural-urban HTC scenario, thus, refers to 75,621 Mg FM/a (Table 1).

The HTC plant is owned and operated by the energy company Vattenfall, at the site of its inner-city coal-fired Reuter West CHP plant (Figure 2). The co-location enables the HTC process to use electricity from the CHP plant. Moreover, this is also the site where the HTC coal is co-fired with conventional hard coal to replace the fossil fuel. The selected power plant uses a pulverization coal-firing system and is, thus, highly suitable for the combustion of HTCcoal dust, as considered here.

Due to the lack of inner-city storage space, the urban biomass accumulated by the private gardening and landscaping firms is prepared and stored outside Berlin (first transport stage), at the site of a composting facility in Ahrensfelde (Figure 2). The preparation and storage of the rural biomass, in turn, proceeds at two composting facilities located in Brandenburg/Havel and Potsdam, and at a collection point in Nauen. While the grass cuttings collected at the municipal green-waste collection points in Havelland are transported to the preparation-and-storage site in Nauen (first transport stage), the grass cuttings prepared and stored in Brandenburg/Havel 
and Potsdam are already collected on-site and, thus, do not need any additional transport. After preparation and storage, the rural and urban biomass is transferred (second transport stage) to the urban HTC plant and co-firing site at the Reuter West CHP plant.

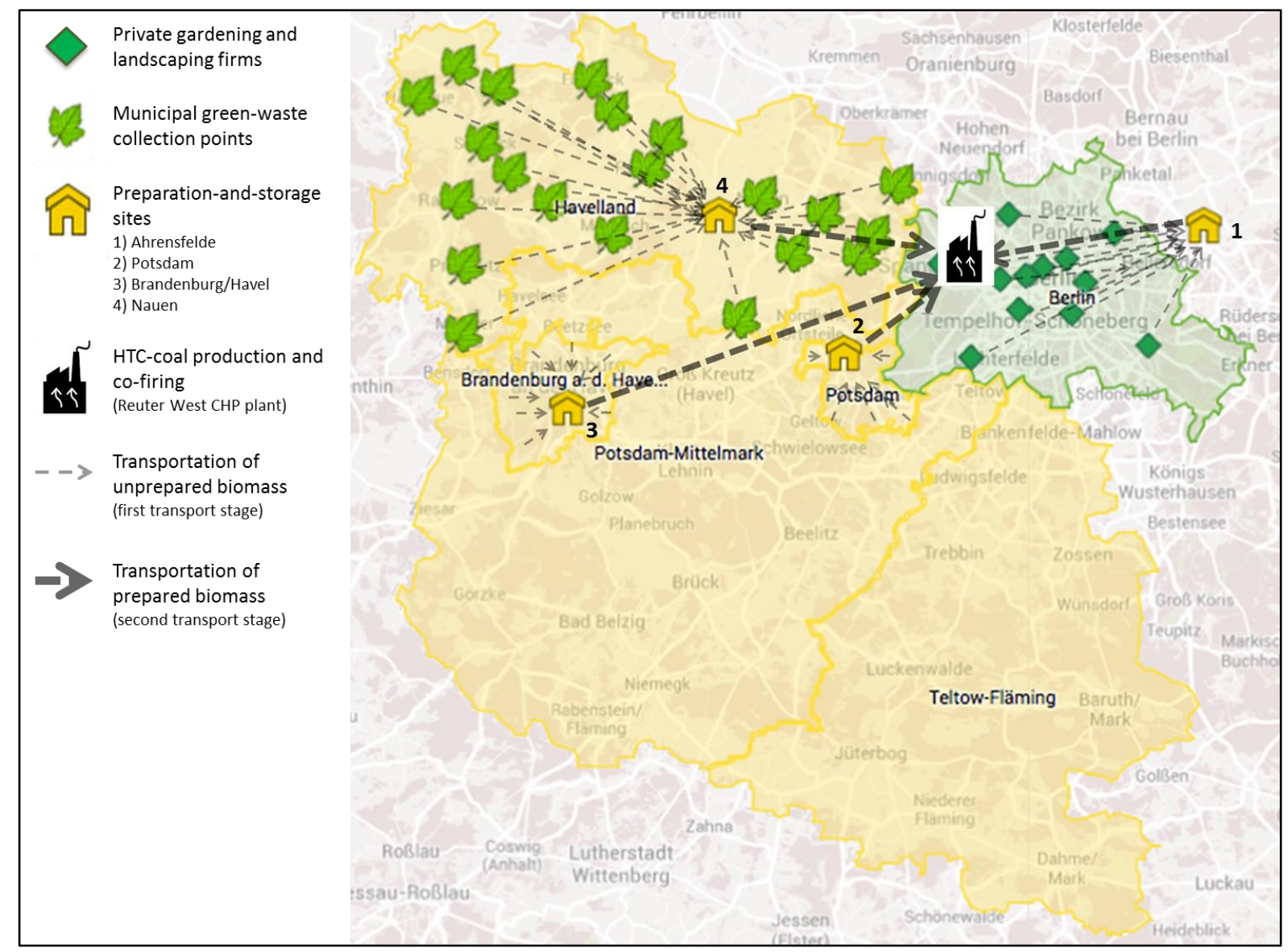

Figure 2: Logistics Concept of the Rural-Urban HTC Scenario

Source: Own illustration, based on Google Maps.

\subsection{3) Rural HTC Scenario}

In the rural HTC scenario, the HTC plant is set up in the surroundings of Berlin, with feedstocks solely derived from the rural areas of Potsdam-Mittelmark and Teltow-Fläming. Thus, the scenario's biomass input amounts to $81,361 \mathrm{Mg}$ FM/a rural grass cuttings (Table 1).

We assume that the rural HTC plant is owned and operated by a composting facility outside Berlin, in Jühnsdorf, one of the largest composting facilities in the region (Rettenberger et al. 2012: 283). As illustrated in Figure 3, we further assume that the feedstocks collected at the municipal green-waste collection points in Potsdam-Mittelmark [Teltow-Fläming] are transferred (first transport stage) to an existing recycling center in Werder [Ludwigsfelde] for preparation and storage. From the preparation-and-storage sites, the feedstocks are transported (second transport stage) to the HTC plant in Jühnsdorf, where they are processed into HTC coal. Finally, the pulverized HTC coal is sold and transported (third transport stage) to Vattenfall's inner-city Reuter West CHP plant for HTC-coal co-firing, i.e. the same co-firing site as already considered in the rural-urban HTC scenario. 


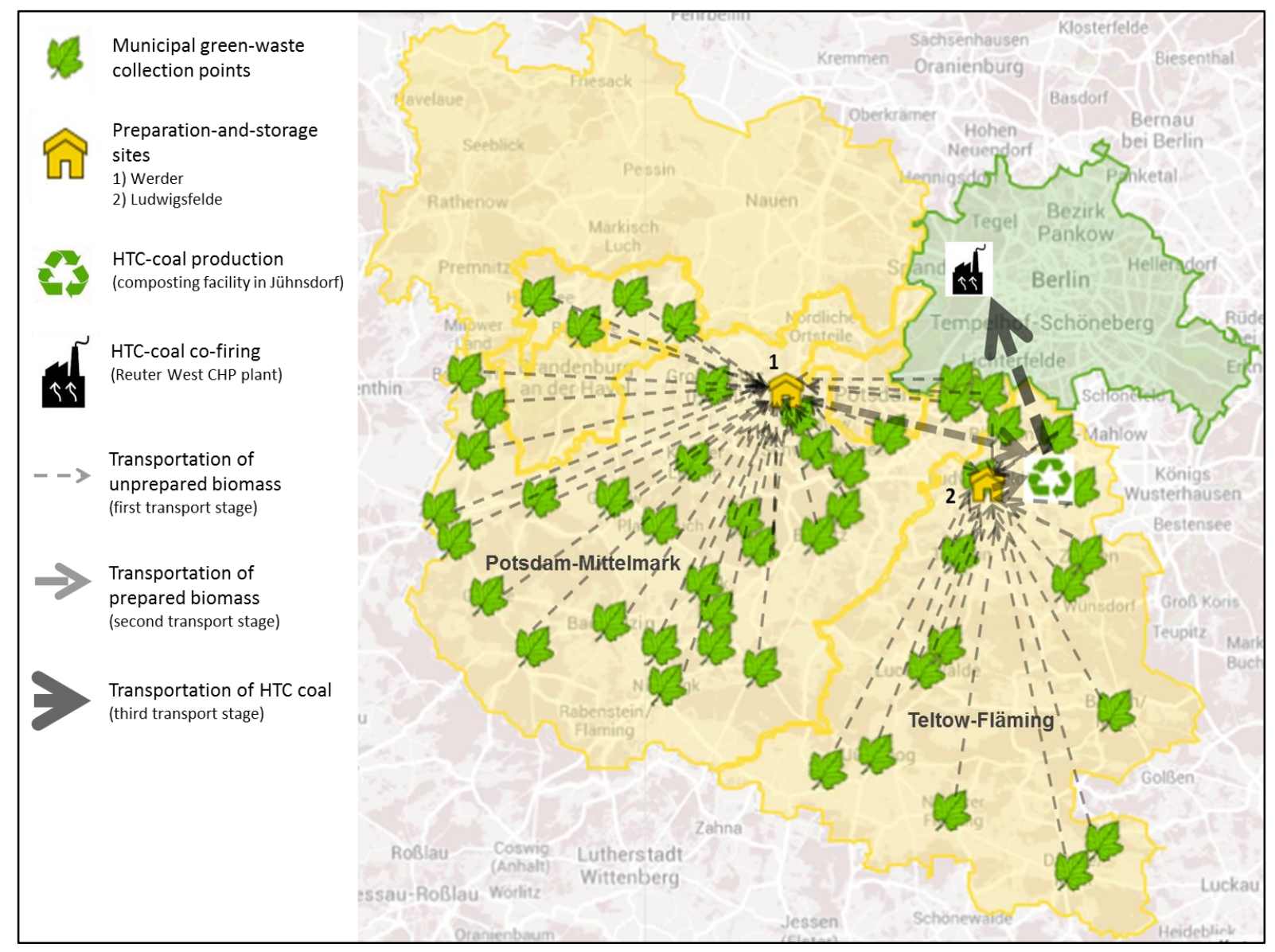

Figure 3: Logistics Concept of the Rural HTC Scenario

Source: Own illustration, based on Google Maps.

\section{2) Life-Cycle Stages and System Boundaries}

The life-cycle stages and system boundaries used throughout the analysis for the three HTC scenarios and their corresponding reference cases are illustrated in Figure 4. Generally, we take a cradle-to-grave life-cycle perspective, covering multiple actors along the entire life cycle (lifecycle view). For the LCC approach, however, we also take the more restricted view of the potential investor into the HTC facility (including all life-cycle stages related to the HTC investment) to evaluate the private business incentives to start HTC-coal production (HTCinvestor view).

\subsection{1) Life-Cycle View}

The cradle-to-grave life-cycle perspective in the HTC scenarios consists of the energy and material streams leading from the collected biomass to the final products electricity and heat, generated from HTC coal. In the corresponding reference scenarios, we reach system equivalence by considering two autonomous processes, the production of compost and its soil application, on the one hand, and the generation of energy from hard coal, on the other hand. This approach follows Rehl and Müller (2013), who compare a system of anaerobic digestion with a corresponding reference system of composting and fossil-energy generation. 


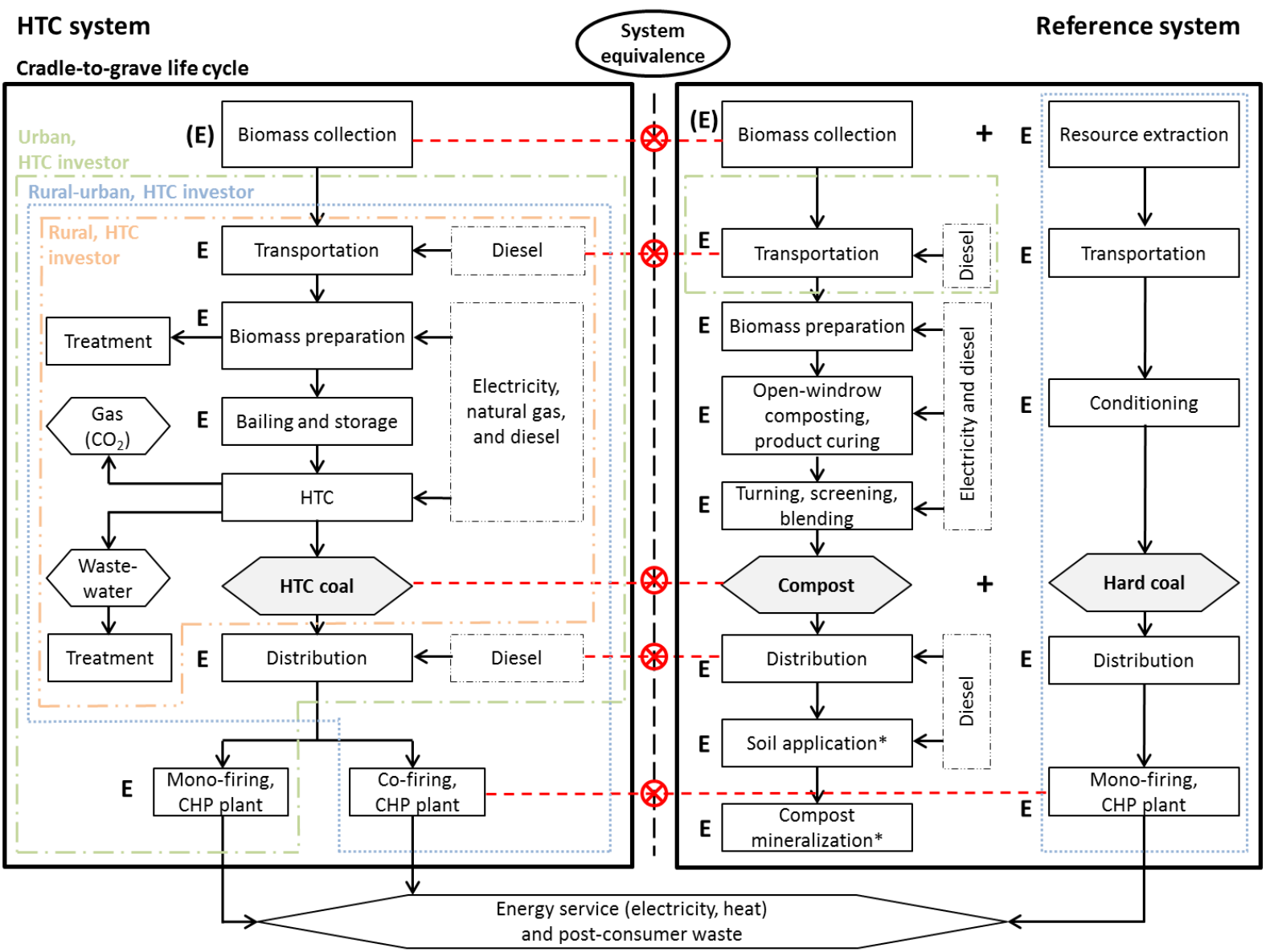

Figure 4: Life-Cycle Stages and System Boundaries of the HTC and Reference Systems

Sources: Own illustration, adapted from Rehl and Müller (2013: 17); Cherubini (2010: 1569); Roberts et al. (2010: 828); and NSW Department of Environment and Conservation (2007: 24).

Notes: The crosses indicate parallel life-cycle stages or procedures within the HTC and reference systems. * = In substitution for mineral fertilizers (including upstream emissions). $\mathbf{E}=$ Emissions released along the life cycle.

HTC-investor view: We assume that the owner and operator of the HTC plant is also in charge of biomass transportation and biomass preparation, baling, and storage. In the rural reference scenario, none of the life-cycle stages are relevant for the potential HTC investor, the composting facility in Jühnsdorf, since we assume that HTCcoal production is purely additional to its business (cf. Section 2.2.2).

The left-hand side of Figure 4 illustrates the life-cycle stages related to the HTC system. During the first stage, the HTC input material (leaves and grass cuttings) is collected by the respective waste-management authorities/companies in each of the three HTC scenarios. This stage is neither ascribed with emissions nor with costs since the green waste we consider must be disposed of in any case and, thus, must be collected regardless of its further use. However, we assume that the waste-management authorities/companies earn tipping fees for the biomass collections as if the green waste was dropped off at their biomass collection points. In the second stage, the biomass is bundled and transported to the preparation-and-storage sites, as described in detail in the logistics concepts of the HTC scenarios (Section 2.1). Biomass preparation takes place before storage and comprises the screening, sieving, separating, and crushing of the fresh input material. In order to eliminate biomass losses during storage, the prepared biomass is further baled. After storage, the biomass is transported to each scenario's respective HTC plant, where it is converted into pulverized HTC coal. In a final stage, the HTC 
coal is distributed to the combustion site (if different from the site of the HTC plant), where it is used for energy generation in mono- or co-firing CHP applications.

Turning to the reference scenarios, the right-hand side of Figure 4 shows the life-cycle stages associated with composting and fossil-energy generation. With regard to composting, we consider the biomass transportation, biomass preparation, and activities accompanying the curing process (turning, screening, and blending), as well as the distribution, soil application, and mineralization of the compost (in substitution for mineral fertilizers). The logistics concepts for biomass and compost transportation are less sophisticated than those for HTC (see Section 3.1.2). We assume open-windrow composting, as predominant in the surroundings of Berlin (Vogt et al. 2012). The generation of fossil energy (electricity and heat), in turn, is achieved through the combustion of hard coal. The respective life-cycle stages include all the extractive, transport-related, and conditioning efforts to provide the hard coal (i.e. all upstream or precombustion efforts), as well as the distribution and combustion of the fossil fuel. In all reference scenarios, we assume that the hard coal is mono-fired at the Reuter West CHP plant.

In terms of emission sources, we focus on variable inputs of electricity, heat (natural gas), and diesel fuel into the HTC and reference systems. For reasons of simplicity, GHG emissions related to fixed material and energy inputs into buildings, installations, and equipment are not included in the analysis. In particular, we do not ascribe any emissions to the construction of the HTC plants, composting facilities, and power plants. Finally, emissions related to postconsumer waste and energy servicing (grid distribution) are also beyond the system boundaries.

\subsection{2) HTC-Investor View}

Since multiple actors are active along the HTC life cycle, the cradle-to-grave life-cycle view in the HTC and reference scenarios differs from the perspective of the potential investor into the HTC facility (see Figure 4). In particular, the substitution of hard coal by HTC coal is not taken into account by $B S R$, the owner and operator of the HTC facility in the urban HTC scenario, since BSR mono-fires the HTC coal in its newly built biomass CHP plant. Moreover, BSR is just the third-party manager of the parks departments' biomass collections. The same is true for Vattenfall in the rural-urban HTC scenario, which is neither responsible for the collection nor the disposal of the green waste it uses for HTC-coal production. In the rural HTC scenario, the composting facility in Jühnsdorf is only the producer of the HTC coal, while the HTC coal is purchased for combustion by Vattenfall. Further, we assume that the composting facility in Jühnsdorf is not usually in charge of collecting and disposing of the biomass that enters its HTC-coal production. That is, the production of HTC coal does not substitute for its composting business, which is assumed to draw on biomass resources outside our analysis.

\section{3) Life-Cycle Sustainability Assessment}

The specific life-cycle sustainability assessment we pursue is in line with the ISO 14040/14044 requirements (ISO 2006) established for traditional LCAs. In the following, we present the methodological details for the environmental LCA, the LCC approach, and the SLCA.

\subsection{1) Life-Cycle Assessment}

In the LCA, we focus on GHG emissions as the sole indicator of environmental sustainability. That is, the LCA provides a GHG balance to account for the GHG emissions associated with 
the three HTC scenarios and their corresponding reference cases. The GHG mitigation potential of HTC coal (in $\mathrm{Mg} \mathrm{CO}_{2} \mathrm{e} / \mathrm{a}$ ) is then obtained by subtracting the GHG emissions of a given HTC scenario, $E_{H T C}$ (in $\mathrm{kg} \mathrm{CO}_{2} \mathrm{e} / \mathrm{Mg} \mathrm{FM}$ input), from the GHG emissions of the reference case, $E_{\text {Reference }}$ (in $\mathrm{kg} \mathrm{CO} 2 \mathrm{e} / \mathrm{Mg} \mathrm{FM}$ input), dividing the difference by 1,000 , and multiplying it by the annual biomass input (in Mg FM/a). ${ }^{15}$

\subsection{2) Life-Cycle Costing Approach}

In the first step of the economic assessment, i.e. in the LCC approach, we depict the private (or direct, internal) costs and revenues that are either borne along the entire cradle-to-grave life cycle (life-cycle view) or by the potential investor into the HTC facility (HTC-investor view). To measure the degree of economic profitability of a given HTC scenario over its respective reference case, we use a dynamic investment appraisal, calculating each scenario's NPV.

Life-cycle view. A scenario's NPV in the life-cycle view, $N P V_{L C C}$, is obtained as:

$N P V_{L C C}=-C_{0}+\sum_{t=1}^{T} \frac{C F_{t, L C C}}{(1+i)^{t}}$

where $C_{0}$ indicates the initial investment costs (only applicable in the HTC scenarios), $C F_{t, L C C}$ refers to the cash flows (i.e. revenues - costs) over all life-cycle stages - possibly involving different economic actors - in year $t, T$ is the time horizon (assumed to be 20 years), and $i$ denotes the discount rate. The discount rate is defined as the weighted average of capital costs:

$i=\frac{i_{\text {equityEquity }+i_{\text {debt }} \text { Debt }}}{\text { Equity }+ \text { Debt }}$

where $i_{\text {equity }}$ is the equity interest rate $(\%), i_{\text {debt }}$ is the debt interest rate (\%), Equity is the total amount of equity $(€)$, and Debt is the total amount of debt $(€)$. The debt interest rate, $i_{d e b t}$, is oriented at the average rate of $4 \%$ offered by $\mathrm{KfW}$, a public promotional bank in Germany, for renewable-energy projects (KfW 2017). The average equity interest rate, $i_{\text {equity }}$, is assumed to be about $9 \%$. For simplicity, we use an equal share of debt and equity, resulting in a discount rate of $i=6.5 \%$ applied in all scenarios.

While $N P V_{L C C}<0$ indicates that a project - any of the HTC or reference scenarios - is not profitable and, thus, should not be pursued, $N P V_{L C C}>0$ means that a project is profitable in absolute terms. Since the biomass considered in our analysis can be used either for HTC or for composting, what matters, given absolute profitability, is whether an HTC scenario is more profitable than its reference case. In other words, what matters is whether HTC-coal production and combustion in a specific HTC scenario is more profitable than biomass composting (combined with the soil application of the compost to replace mineral fertilizers) and energy generation from hard coal. This will be the case if the HTC scenario's $N P V_{L C C}$ exceeds that of the reference scenario.

HTC-investor view. Just focusing on the potential investor into the HTC facility, we provide a second version of the NPV, $N P V_{\text {investor: }}$ :

$N P V_{\text {investor }}=-C_{0}+\sum_{t=1}^{T} \frac{C F_{t, \text { investor }}}{(1+i)^{t}}$,

where $C F_{t, \text { investor }}$ refers to the cash flows incurred by the HTC investor only.

\footnotetext{
${ }^{15}$ Note that we omit any scenario-related index in the variables we use.
} 
While the sign of an HTC scenario's $N P V_{\text {investor }}$ reveals whether it is profitable in absolute terms for the potential HTC investor to make the HTC-related investments, the comparison of the (positive) $N P V_{\text {investor }}$ values between a given HTC scenario and its respective reference case indicates whether the investor prefers the HTC project to the investor-related status quo. More precisely, the comparison answers the following questions: Is it more profitable for $B S R$ to start HTC-coal production and combustion than to have its own collected feedstocks composted (urban scenario)? Is it worthwhile for Vattenfall to enter into HTC-coal production and combustion in order to substitute for hard-coal combustion (rural-urban scenario)? Is it profitable for the composting facility in Jühnsdorf to add HTC-coal production to its current composting business (rural scenario)?

\subsection{3) Social Life-Cycle Assessment}

The LCC approach is complemented by a social life-cycle assessment, which adds the social (or indirect, external) costs to the private costs incurred along the entire cradle-to-grave life cycle. The social costs refer to the physical damage costs imposed on society by the emissions of greenhouse gases. Accordingly, we define a third version of the NPV, $N P V_{S L C A}$ :

$$
N P V_{S L C A}=-C_{0}+\sum_{t=1}^{T} \frac{C F_{t, L C C}+C F_{t, S L C A}}{(1+i)^{t}}
$$

where $C F_{t, S L C A}$ refers to the cash flows associated with the social costs of carbon. The underlying GHG emissions are those calculated in the LCA.

\section{4) Carbon Abatement Costs}

Building on the life-cycle sustainability assessment, in particular, on the LCA and the LCC approach (life-cycle view), we finally calculate the carbon abatement costs associated with HTC coal. The carbon abatement costs refer to the costs to mitigate one unit of $\mathrm{CO}_{2} \mathrm{e}$ by using HTC coal instead of hard coal to generate electricity and heat, if the HTC coal is produced from leaves and grass cuttings that are diverted from composting (and the subsequent soil application of the compost to replace mineral fertilizers). Thus, the carbon abatement costs, $A C(€ / \mathrm{Mg}$ $\mathrm{CO}_{2} \mathrm{e}$ ), are calculated by dividing the difference in the annual (net) life-cycle costs between an HTC scenario, Annuity ${ }_{H T C}(€ / \mathrm{a})$, and its reference case, Annuity Reference $_{(}(€ / \mathrm{a})$, by the difference in the annual GHG emissions between the reference case, $E_{\text {Reference }}\left(\mathrm{Mg} \mathrm{CO}_{2} \mathrm{e} / \mathrm{a}\right)$, and the HTC scenario, $E_{H T C}\left(\mathrm{Mg} \mathrm{CO}_{2} \mathrm{e} / \mathrm{a}\right)$ (cf. McKinsey 2009):

$A C=\frac{\text { Annuity }_{H T C}-\text { Annuity }_{\text {Reference }}}{E_{\text {Reference }}-E_{H T C}}, \quad$ if $E_{\text {Reference }}-E_{H T C}>0$.

While the GHG emissions for the $A C$ calculation are taken directly from the LCA, the annual (net) costs along the entire cradle-to-grave life cycle are derived from the LCC approach. In particular, we have:

Annuity $_{z}=\left|N P V_{L C C}^{\prime}\right|\left[\frac{(1+i)^{T} i}{(1+i)^{T}-1}\right], \quad$ with $z \in\{H T C$, Reference $\}$.

That is, we calculate the annual (net) life-cycle costs by the annuity method, which transforms the absolute value of the relevant discounted cash flows from the LCC approach (life-cycle 
view) into uniform annual values. Since the cash flows applied for the $A C$ calculation slightly differ from those used in equation (1), we define:

$N P V^{\prime}{ }_{L C C}=-C_{0}+\sum_{t=1}^{T} \frac{C F_{t, L C C}^{\prime}}{(1+i)^{t}}$

where $C F^{\prime}{ }_{t, L C C}$ denotes the modified cash flows.

\section{3) Data}

Let us turn to the data we use for the life-cycle sustainability assessment and the calculation of the carbon abatement costs. Any necessary calculations are performed with the help of Excel spreadsheets. Thus, most of the values that we present are rounded.

\section{1) Life-Cycle Assessment}

In order to calculate the GHG emissions associated with the three HTC scenarios and their corresponding reference cases, we first derive the scenarios' mass and energy balances.

The characteristics of the HTC process and resulting HTC coal are largely based on data provided by SunCoal (SunCoal 2012), reflecting their industrial-scale demonstration facility in Ludwigsfelde, Brandenburg, and their self-developed CarboREN ${ }^{\circledR}$ technology.

\subsection{1) Mass Balances}

Measured at an HTC-coal dry-matter (DM) content of 92\%, rural grass cuttings and urban leaves yield $24.4 \%$ HTC coal per unit of initial untreated FM input, while urban grass cuttings produce $17.3 \%$ HTC coal (Table 2). The different HTC-coal yields are driven by feedstock properties: Rural grass cuttings and urban leaves have a water content of about $54 \%$ and contain $16 \%$ inert material (Table 2). Due to an early harvest and a high frequency of cutting (Vogt et al. 2012), urban grasses usually have a higher water content of $75 \%$ and contain just $3.8 \%$ inert material (Table 2). With the highest share of urban grass cuttings (Table 1), the urban HTC scenario generates the lowest amount of HTC coal, 16,641 Mg HTC coal/a, while the ruralurban HTC scenario produces $17,446 \mathrm{Mg} \mathrm{HTC}$ coal/a. The rural HTC scenario, in turn, has the highest output of HTC coal, 19,852 Mg HTC coal/a, due to the sole input of rural grass cuttings.

With regard to composting, leaves generally result in a higher share of compost (40\%) than grass cuttings $(18 \%)$, mostly because a larger volume of gases $-\mathrm{CO}_{2}, \mathrm{CH}_{4}$, and nitrous oxide $\left(\mathrm{N}_{2} \mathrm{O}\right)$ - is formed during the rotting process of grass cuttings (Table 2). Thus, the compost yields in the reference scenarios vary according to the proportions of leaves and grass cuttings in the feedstock mix. Based on the data in Tables 1 and 2, the total compost output in the urban reference scenario amounts to $25,323 \mathrm{Mg} / \mathrm{a}$, while the rural-urban reference scenario generates $15,774 \mathrm{Mg} / \mathrm{a}$ compost, and the rural reference scenario only 14,645 Mg/a.

\subsection{2) Energy Balances}

For each HTC scenario, Table 3 contrasts the energy inputs to the energy outputs. It further contains the composting-related energy inputs for the reference scenarios. All remaining energy 
flows are not explicitly identified, but will be covered indirectly in the emission factors to be used. To simplify the analysis, we focus on variable energy inputs along the cradle-to-grave life cycle, leaving aside fixed energy investments into buildings, installations, and equipment.

Input material. For the low-moisture inputs of rural grass cuttings and urban leaves, we apply a lower heating value (LHV) of $5.0 \mathrm{MJ} / \mathrm{kg}$ FM (cf. Zentner 2013: 8; Vogt et al. 2012: 121). The LHV of high-moisture urban grass cuttings is assumed to be $3.6 \mathrm{MJ} / \mathrm{kg} \mathrm{FM}$, deducted from the LHV of HTC coal (at a 92\% DM content) of $20 \mathrm{MJ} / \mathrm{kg}$ HTC coal (SunCoal 2012: 2) and the corresponding HTC-coal yield of $17.3 \%$ (Table 2). Depending on the feedstock mix (Table 1), the LHVs of the initial, unprepared FM biomass in the three scenarios are given in Table 3, measured in kilowatt hours (kWh) per Mg FM input.

Transportation. For all the transportation outlined in the logistics concepts of the HTC scenarios (Section 2.1), we assume semi-trailer trucks running on fossil diesel. Table 4 contains the detailed characteristics for the semi-trailer trucks, such as diesel consumption and loads per tour. Tables 5 to 7 , in turn, compile all the single routes, $r$, and kilometers $(\mathrm{km})$ travelled from the respective biomass collection points to the locations of biomass preparation and storage, HTC-coal production, and HTC-coal combustion. Due to its complex logistics concept, the urban HTC scenario (Section 2.1.1) has the highest transport energy consumption (Table 3), followed by the rural HTC scenario, which also includes three transport stages (Section 2.1.3). With only two transport stages (Section 2.1.2), the rural-urban HTC scenario has the lowest energy requirements for transport.

While also based on semi-trailer trucks, the reference scenarios assume that the collected biomass is transported to local composting facilities at an average distance of $30 \mathrm{~km}$ before the compost is distributed to its final consumers within a 20-km radius (Tables 8 to 10). However, in the rural-urban reference scenario, no transports occur for the rural grass cuttings that accrue in Brandenburg/Havel and Potsdam since they are already collected at composting facilities (cf. Section 2.1.2).

Baling and storage. Further energy inputs relate to the preparation, baling, and storage of the collected biomass (Table 3). However, the energy used for biomass preparation can be found under auxiliary energy requirements. Concerning bailing and storage, we assume that the prepared biomass is stored in a free-space storage area at the respective preparation-and-storage sites. To eliminate biomass degradation during storage, the prepared biomass is pressed to round film bales. We assume a baling-press electricity consumption of $3.0 \mathrm{kWh}$ per $\mathrm{Mg}$ initial FM input (i.e. $\mathrm{kWh} / \mathrm{Mg}$ FM input) and a diesel use of $5.0 \mathrm{kWh} / \mathrm{Mg}$ FM input for the feeding of the baling press (Vogt et al. 2012: 221). The energy demand associated with the production of foil is neglected.

In the reference scenarios, the fresh biomass is directly fed into the composting process, such that no biomass storage occurs. Energy inputs for biomass preparation are covered under auxiliary energy requirements.

Auxiliary energy requirements. In the HTC scenarios, auxiliary energy takes the form of electricity, natural gas, and diesel (Table 3). In particular, the preparation of biomass at the preparation-and-storage sites requires $5.0 \mathrm{kWh} / \mathrm{Mg}$ FM input of electricity (ICU, unpublished data). Feeding the prepared biomass into the HTC reactor further necessitates $3.0 \mathrm{kWh} / \mathrm{Mg} \mathrm{FM}$ input of diesel (cf. Vogt et al. 2012: XXVI). Depending on the scenario, 31.0-34.2 kWh/Mg FM input of energy from natural gas (Table 3 ) has to be provided to heat the biomass slurry up to the HTC reaction temperature, assumed to be $200^{\circ} \mathrm{C}$. Another $52.5-58.0 \mathrm{kWh} / \mathrm{Mg} \mathrm{FM}$ input of electricity is used for thermally drying the HTC coal to a DM content of $92 \%$ (Table 3). ${ }^{16}$ In the urban HTC scenario, the electricity is obtained from the $B S R$ waste-incineration plant located at the site of the HTC plant. The rural-urban HTC scenario, in turn, uses electricity from

\footnotetext{
${ }^{16}$ A DM content of $92 \%$ is regarded as the minimum threshold for the pulverization of HTC coal (SunCoal 2012).
} 
hard coal combusted at the Reuter West CHP plant, where the HTC plant is co-located. Finally, in the rural HTC scenario, the electricity is obtained from the German electricity grid. ${ }^{17}$

In the reference scenarios, open-windrow composting has a total diesel consumption for biomass receipt, shredding, composting, screening, and dispatch of 2.5 liters/Mg FM input (Vogt et al. 2012: 116), equivalent to $24.9 \mathrm{kWh} / \mathrm{Mg}$ FM input (Table 3). Additionally, the composting process requires $0.5 \mathrm{kWh} / \mathrm{Mg} \mathrm{FM}$ input of electricity for stationary equipment and buildings (Vogt et al. 2012: 116), obtained from the German electricity grid.

Usable energy from HTC coal. Turning to the energy outputs associated with the HTC scenarios, the concentration of carbon in the HTC coal and dewatering result in a higher LHV for a $\mathrm{kg}$ of HTC coal than for a $\mathrm{kg}$ of the initial biomass. Regardless of the type of feedstock used, the LHV of HTC coal amounts to about $20 \mathrm{MJ} / \mathrm{kg}$ HTC coal (SunCoal 2012: 2), calculated at a $92 \%$ DM content of HTC coal. Combined with the HTC-coal mass yields (Section 3.1.1) and the total biomass inputs (Table 1), the scenario-specific energy contents of HTC coal in $\mathrm{kWh} / \mathrm{Mg}$ FM input are given in Table 3.

To obtain the usable energy from HTC coal, the energy content of HTC coal must be reduced by the energy conversion losses occurring during combustion. The losses in each scenario depend on the respective CHP plant's heat- and electricity-related efficiencies. In particular, the urban HTC scenario assumes that the HTC coal is mono-fired in a newly installed biomass CHP plant with a total efficiency, $\eta_{t o t}$, of $92 \%$ (electrical efficiency: $22 \%$; thermal efficiency: 70\%) (Obernberger and Thek 2004: 6). The rural-urban and rural HTC scenarios, in turn, are based on HTC-coal co-firing at the total efficiency of the Reuter West CHP plant of $\eta_{\text {tot }}=72 \%$ (electrical efficiency: 33\%; thermal efficiency: 39\%) (Vogt et al. 2012: III). Due to the higher conversion efficiency (and despite the lowest energy content of the HTC coal, see Table 3), the urban HTC scenario provides the highest amount of usable energy from HTC coal, 1,154.1 kWh/Mg FM input, compared to $922.8 \mathrm{kWh} / \mathrm{Mg}$ FM input and $976.0 \mathrm{kWh} / \mathrm{Mg}$ FM input, respectively, in the rural-urban and rural HTC scenarios (Table 3).

Overall energy balance and system efficiency. Subtracting the total energy input from the usable energy from HTC coal, all HTC scenarios are associated with net energy losses (Table 3). Largely driven by the higher conversion efficiency, the net energy loss in the urban HTC scenario amounts to $283.4 \mathrm{kWh} / \mathrm{Mg}$ FM input only, while the rural-urban and rural HTC scenarios run net energy losses of $519.0 \mathrm{kWh} / \mathrm{Mg} \mathrm{FM}$ input and $537.5 \mathrm{kWh} / \mathrm{Mg} \mathrm{FM}$ input, respectively.

Further based on the total energy input and the energy content of HTC coal (Table 3), the overall system efficiency of a given HTC scenario, $\eta_{\text {sys }}(\%)$, can be derived as:

$\eta_{\text {sys }}=\frac{\text { Energy content of HTC coal }}{\text { Total energy input }} \eta_{\text {tot }}$.

Again explained by the favorable conversion efficiency of the new biomass CHP plant, the highest system efficiency, $80.3 \%$, is reached in the urban HTC scenario. The rural-urban and rural HTC scenarios obtain respective system efficiencies of $64.0 \%$ and $64.5 \%$.

\subsection{3) Emission Balances}

Combining the mass and energy balances with the emission factors given in Table 11, the GHG emissions associated with the three HTC scenarios, $E_{H T C}$, and their respective reference cases, $E_{\text {Reference, }}$, are derived in Table 12, measured in both $\mathrm{kg} \mathrm{CO}_{2} \mathrm{e} / \mathrm{Mg} \mathrm{FM}$ input and $\mathrm{Mg} \mathrm{CO}_{2} \mathrm{e} / \mathrm{a}$.

\footnotetext{
${ }^{17}$ To simplify the analysis, we do not apply any energy requirements and, thus, emissions to the disposal of the residues obtained from the biomass preparation and to the treatment of the HTC wastewater.
} 


\section{2) Life-Cycle Costing Approach}

Within the LCC approach, we provide the private costs and revenues necessary to calculate the $N P V_{L C C}$ and $N P V_{\text {investor }}$ for the three HTC scenarios and their corresponding reference cases.

\subsection{1) Costs}

In our inventory of private costs, we take into account transportation costs, preparation, baling, and storage costs, capital-related costs, consumption-related costs, as well as operation-related costs. We abstract from any administrative costs, rents, insurance payments, and taxes.

Transportation costs. The annual costs for the transportation of the feedstocks [HTC coal, compost] on a given route $r, C_{\text {trans }, r}(€ / \mathrm{a})$, are obtained by multiplying the distance-related transportation costs per tour (i.e. per round trip) on route $r, C_{\text {tour, } r}(€ /$ tour), by the number of tours, tour $_{r}$, on that route:

$C_{\text {trans }, r}=C_{\text {tour }, \text { r }}$ tour $_{r}$

Following Leible (2003: 85), $C_{\text {tour, } r}$ is calculated as:

$C_{\text {tour }, r}=c\left(\frac{2 d_{r}}{s_{r}}+t_{\text {to }}+t_{\text {from }}+t_{\text {on }}+t_{\text {off }}+t_{\text {man }}\right)$

where $c$ refers to the transportation costs per hour (h) in $€ / \mathrm{h}$, including all capital-related, consumption-related, and operation-related costs (i.e. also those for diesel fuel, cf. Table 3). These are derived from a full-cost accounting of a semi-trailer truck with a loading capacity of $40 \mathrm{~m}^{3}$ and a maximum cargo load of $20 \mathrm{Mg}$ (Zentner 2013: 12; Table 4), amounting to approximately $71.7 € / \mathrm{h}$ (Leible 2003: 257). Furthermore, $d_{r}$ is the one-way transportation distance for route $r$ in $\mathrm{km}$. To capture the total travel distance, it is multiplied by factor 2 . The one-way transportation distances can be found in Tables 5 to 7 for the HTC scenarios and in Tables 8 to 10 for the reference scenarios. While $s_{r}$ denotes the average speed and is assumed to be $50 \mathrm{~km} / \mathrm{h}, t_{t o}, t_{\text {from }}, t_{o n}, t_{\text {off }}$, and $t_{\text {man }}$ are the respective times required for the journey from the truck stations to the feedstock [HTC-coal, compost] locations and back, for on- and offloading the feedstocks [HTC coal, compost], and for semi-trailer maneuvering. The time for loading, $t_{o n}$, is set at $0.6 \mathrm{~h}$, while unloading, $t_{\text {off }}$, takes an estimated $0.2 \mathrm{~h}$; and the time for traveling to and from the feedstock [HTC-coal, compost] locations (including maneuvering activities), $t_{t o}+t_{\text {from }}+t_{\text {man }}$, is projected to be $0.7 \mathrm{~h}$ (Leible 2003: 258).

In turn, the number of tours, tour $_{r}$, on route $r$ depends on the amount of feedstocks [HTC coal, compost] transported per tour (Tables 5 to 10) and on the respective load per tour (in $\mathrm{Mg}$ /tour) as given in Table 4. The values for tour $_{r}$ are displayed in Tables 5 to 10 along with the annual transport costs, $C_{\text {trans, } r \text {. }}$

Preparation, baling, and storage costs. For biomass preparation in the HTC scenarios, a levelized cost of $15.0 € / \mathrm{Mg}$ FM input is ascribed (Table 13), including the costs for electricity use (cf. Table 3). The residues left behind after preparation - a mixture of inert material (e.g., stones and plastics), water, and organics - are internally disposed of at $4.9 € / \mathrm{Mg} F M$ input (Table 13). The share of residues amounts to $32.4 \%$ for rural grass cuttings and urban leaves, and to $5.0 \%$ for urban grass cuttings (Table 2).

The total annual costs for baling and storage, $C_{\text {stor }}(€ / \mathrm{a})$, in the HTC scenarios consist of the expenditures for the provision, supervision, and maintenance of the free-space storage area, as well as of the costs for biomass baling and covering the bales with foil: 
$C_{\text {stor }}=c_{\text {over }} m_{\text {prep }}+c_{\text {bale }}\left(\frac{m_{\text {prep }}}{b_{\text {dens }} b_{\text {vol }}}\right)$

where $c_{\text {over }}$ refers to the levelized overhead costs for storage ( $\left.€ / \mathrm{Mg} \mathrm{FM}_{\mathrm{prep}}\right), m_{\text {prep }}$ to the annual amount of biomass after preparation $\left(\mathrm{Mg} \mathrm{FM}_{\text {prep }} / \mathrm{a}\right), c_{\text {bale }}$ to the levelized baling costs (including all capital-, consumption-, and operation-related costs, i.e. also those for electricity and diesel, cf. Table 3) $(€ /$ bale $), b_{\text {dens }}$ to the bale density $\left(\mathrm{Mg} \mathrm{FM}_{\text {prep }} / \mathrm{m}^{3}\right)$, and $b_{\text {vol }}$ to the bale volume $\left(\mathrm{m}^{3}\right)$. The data entering equation (11) are presented in Table 14 . Note that $m_{\text {prep }}$ coincides with the annual capacity of an HTC plant, i.e. 55,000 Mg FM $\mathrm{prep}_{\text {a }}$ in each HTC scenario.

In the reference scenarios, we do not have to include any costs for baling and storage since the fresh biomass is directly fed into the composting process. The costs for biomass preparation, in turn, are covered under consumption- and operation-related costs.

Capital-related costs. Based on information provided by SunCoal (2012: 7) for their internally developed technology, the investment costs in $t=0$ for the installation of an HTC plant in any given HTC scenario are $€ 15,000,000$ (Table 13).

The investment costs in $t=0$ for the biomass CHP plant built in the urban HTC scenario amount to $€ 16,958,000$ (Table 15). This is based on Obernberger and Thek (2004), who provide an economic evaluation of a Danish biomass CHP plant of similar size, based on a steamturbine process.

The annual capital-related costs for open-windrow composting in the reference scenarios (except for the HTC-investor view) are derived from the specific capital costs of $9 € / \mathrm{Mg} F M$ input (van Haaren et al. 2010: 2654). Thus, when multiplied by the respective biomass potentials from the last column of Table 1, the annual capital-related costs for composting amount to $663,310 € / \mathrm{a}$ in the urban reference scenario, $680,585 € / \mathrm{a}$ in the rural-urban reference scenario, and 732,249 €/a in the rural reference scenario.

For the Reuter West CHP plant that is used for HTC-coal co-firing in the rural-urban and rural HTC scenarios as well as for hard-coal combustion in the reference scenarios, no capitalrelated costs occur. The reason is that the two blocks of the plant have already been in existence since 1987 and 1989, respectively (Vattenfall 2017), and are assumed to be fully written off. Thus, the reduction of hard-coal combustion in the urban HTC scenario due to HTC-coal monofiring in the new BSR biomass CHP plant has no impact on the installed capacity at the Reuter West CHP plant. Moreover, in the rural-urban and rural HTC scenarios, HTC-coal co-firing in substitution for hard coal renders any additional capacity installation superfluous. We further assume that no retrofitting of the Reuter West CHP plant is required for HTC-coal co-firing. Thus, only consumption- and operation-related costs will be relevant.

Consumption-related costs. Consumption-related variable costs refer to all expenditures for auxiliary electricity, heat (natural gas), and diesel fuel not yet covered under transportation costs and preparation, baling, and storage costs, as well as for any other inputs required in the respective conversion processes.

Starting with the HTC scenarios, the specific auxiliary energy requirements for the HTC process - diesel fuel for feeding the biomass into the HTC reactor, natural gas for heating the biomass slurry in the reactor, and electricity for thermally drying the HTC coal - in $\mathrm{kWh} / \mathrm{Mg}$ FM input are given in Table 3. The corresponding prices are summarized in Table 13. In particular, we use the 2014-2016 average prices for electricity and natural gas for industrial customers of $0.0814 € / \mathrm{kWh}$ (Statista 2017a) and $0.03 € / \mathrm{kWh}$ (Statistisches Bundesamt 2017a: 22), respectively, and the April 2016-April 2017 average German diesel price of $1.12 € /$ liter (Statista 2017b). However, for HTC-coal drying in the urban and rural-urban HTC scenarios, we replace the $0.0814 € / \mathrm{kWh}$ electricity price by the 2016 average end-of-month base-load electricity spot-market price of $€ 28$ per megawatt hour (MWh) obtained at the European Energy Exchange (EEX) in Leipzig (EEX 2017a). We do so in order to reflect synergies from the co- 
location of the HTC plant with the $B S R$ waste-incineration plant (urban HTC scenario) and the Reuter West CHP plant (rural-urban HTC scenario).

In addition to the energy requirements for the HTC process, further consumption-related costs in the HTC scenarios occur for fresh-water demand and subsequent HTC-wastewater disposal (Table 13). To run the HTC process, the HTC reactor uses $1,800 \mathrm{~m}^{3} / \mathrm{a}$ of fresh water (SunCoal 2012: 3). According to Statistisches Bundesamt (2017b), the current (2013) price of fresh water is $2.17 € / \mathrm{m}^{3}$ in Berlin (urban and rural-urban HTC scenarios) and $1.52 € / \mathrm{m}^{3}$ in the federal state of Brandenburg (rural HTC scenario). The wastewater from the HTC process, in turn, is treated at $1.5 € / \mathrm{Mg}$ FM input (SunCoal 2012: 5).

Consumption-related costs are also obtained for HTC-coal combustion. In the urban HTC scenario, the consumption-related costs for HTC-coal mono-firing in the newly built biomass CHP plant amount to $376,310 € /$ a (Table 15). They are mainly derived from Obernberger and Thek (2004). However, to allow for synergy effects with the BSR waste-incineration plant, the electricity consumption is priced at the electricity spot-market price of $28 € / M W h$ (EEX 2017a). For HTC-coal co-firing in the Reuter West CHP plant in the rural-urban and rural HTC scenarios, consumption-related costs (variable operating costs) of $1.28 € / \mathrm{MWh}$ are incurred. As detailed in Table 16, these are derived from Hobohm et al. (2011: 135). However, these are not relevant in the HTC-investor view of the rural HTC scenario.

Turning to the reference scenarios, open-windrow composting (including biomass preparation) is associated with specific variable costs of $11 € / \mathrm{Mg}$ FM input (van Haaren et al. 2010: 2654). These are transformed into annual variable costs of $810,713 € / a$ (urban reference scenario), 831,827 €/a (rural-urban reference scenario), and 894,970 €/a (rural reference scenario) when multiplied by the respective biomass totals given in the last column of Table 1 . A share of $21 \%$ of the annual variable costs is associated with energy needs and additives (van Haaren et al. 2010: 2654), i.e. with consumption-related costs (including those for electricity and diesel, cf. Table 3). However, these costs do not exist in the reference scenarios' HTCinvestor view. In the HTC-investor view of the urban reference scenario, instead, BSR pays a tipping fee of $20 € / M g$ FM input (SunCoal 2012: 2) for the composting of the green waste it is obliged to collect. ${ }^{18}$

The total consumption-related costs for the Reuter West CHP plant in the reference scenarios, except for the HTC-investor view in the urban and rural reference scenarios, amount to $23.08 € / \mathrm{MWh}$ (Table 16). In addition to the variable operating costs of $1.28 € / \mathrm{MWh}$, they comprise approximately $18.33 € / \mathrm{MWh}$ of fuel costs and 3.47 €/MWh of carbon costs for hardcoal combustion. The fuel costs are obtained as $c_{f u e l} / \eta_{\text {tot }}$, where $c_{f u e l}$ refers to $13.20 € / \mathrm{MWh}_{\text {fuel }}$ for hard coal free power plant as given in Hobohm et al. (2011: 135), and $\eta_{\text {tot }}$ is the total efficiency of the Reuter West CHP plant of 72\% (Vogt et al. 2012: III). In turn, the carbon costs, $\mathrm{COO}_{2}$, are calculated as:

$$
c_{\mathrm{CO}_{2}}=p_{\mathrm{CO}_{2}} f_{\mathrm{CO}_{2}}
$$

where $f_{\mathrm{CO}_{2}}$ is the hard-coal emission factor of $0.6945 \mathrm{Mg} \mathrm{CO}_{2} \mathrm{e} / \mathrm{MWh}$, derived from Table 11 by adding up the heat- and electricity-related emissions from hard-coal combustion (i.e. already accounting for the CHP conversion efficiency). Moreover, $p_{\mathrm{CO}_{2}}$ refers to the 2016 average price of approximately $5 € / \mathrm{Mg} \mathrm{CO}_{2}$ for European Union (EU) emission allowances traded at the EEX in Leipzig within the framework of the EU Emission Trading Scheme (EU ETS) (EEX 2017b).

Operation-related costs. Operation-related costs mainly address expenses for personnel and service-and-maintenance efforts.

\footnotetext{
${ }^{18}$ Note that we abstract from any costs for the soil application of the compost, assuming that they are about similar to the costs for the soil application of mineral fertilizers.
} 
In the HTC scenarios, they amount to $5.6 € / \mathrm{Mg} \mathrm{FM}$ input $(2.8 € / \mathrm{Mg} \mathrm{FM}$ input for personnel and $2.8 € / \mathrm{Mg}$ FM input for service and maintenance) for the operation of an HTC plant (Table 13). With $418,854 € / \mathrm{a}$ (or $5.7 € / \mathrm{Mg}$ FM input when divided by $73,701 \mathrm{Mg} \mathrm{FM} / \mathrm{a}$, see Table 1), costs of similar magnitude accrue for HTC-coal mono-firing in the new biomass CHP plant in the urban HTC scenario (Table 15). As summarized in Table 16, HTC-coal cofiring in the Reuter West CHP plant in the rural-urban and rural HTC scenarios is associated with operation-related costs of $3.93 € / \mathrm{MWh}$, as derived from Hobohm et al. (2011: 135). However, these are not relevant in the HTC-investor view of the rural HTC scenario.

In the reference scenarios, $79 \%$ of the annual variable costs of composting $(810,713 € / \mathrm{a}$ in the urban reference scenario, 831,827 €/a in the rural-urban reference scenario, 894,970 €/a in the rural reference scenario) are devoted to service-and-maintenance activities (van Haaren et al. 2010: 2654). However, they are not applicable in the HTC-investor view. The operationrelated costs for the Reuter West CHP plant amount to $3.93 € / \mathrm{MWh}$ (Table 16), except for the HTC-investor view of the urban and rural reference scenarios.

Cost summary. All the costs $(€ /$ a) incurred in the HTC scenarios (both for the life-cycle and HTC-investor views) are summarized in Tables 17 to 19; those for the reference scenarios in Tables 20 to 22.

\subsection{2) Revenues}

Potential revenue sources in the HTC scenarios and their corresponding reference cases include sales of electricity and heat, tipping fees for biomass, sales of compost, and sales of HTC coal.

Except for the HTC-investor view in the rural HTC scenario, all the three HTC scenarios earn revenues from the sales of electricity and heat generated from the combustion of HTC coal (Table 13). In the urban HTC scenario, the HTC coal is mono-fired in the newly built biomass CHP plant. This renders the resulting electricity sales eligible for EEG funding. Accordingly, we assume a guaranteed remuneration of $0.1029 € / \mathrm{kWh}$ electricity, as granted by $\S 42$ EEG 2017 (Bundesgesetzblatt 2016) for biomass plants with an electrical capacity of 500 kilowatts $(\mathrm{kW})$ to 5 megawatts (MW) that were installed before April 2017. However, the EEG does not promote heat generation. Therefore, we reward any heat sales with the net-of-taxes heat retail price of $30 € / \mathrm{MWh}$ (Gores et al. 2013: 23). In the urban and rural-urban HTC scenarios, HTC coal is co-fired in the Reuter West CHP plant. Since co-firing is not eligible for EEG funding, the corresponding revenues from the sales of electricity and heat are based on market prices, i.e. the EEX electricity spot-market price of $28 € / \mathrm{MWh}$ (EEX 2017a) and the heat retail price of $30 € / \mathrm{MWh}$ (Gores et al. 2013: 23).

The HTC scenarios have a further source of revenue in the form of biomass tipping fees. Since we abstract from the collection of biomass, the tipping fees earned in the life-cycle view are oriented at the tipping fees for green waste dropped off at the biomass collection points. We apply a value of $120 € / \mathrm{Mg}$ FM input. As detailed in Table 13, this price is derived from the $B S R$ fee of $€ 3$ per leaf sack à $25 \mathrm{~kg}$ brought to its recycling points (BSR 2017). Moreover, it is in line with the fees quoted by other entities for green waste dropped off at their recycling centers, such as $125.25 € / \mathrm{Mg}$ FM in Potsdam-Mittelmark (APM 2017). In the HTC-investor view of the urban HTC scenario, the $120 € / \mathrm{Mg}$ FM input also apply to the $B S R$ biomass collections. Taking over responsibility for the management of the leaves and grass cuttings collected by the parks departments, $B S R$ is further rewarded with a tipping fee of $20 € / \mathrm{Mg}$ FM input (SunCoal 2012: 2) for the parks departments' biomass. Likewise, Vattenfall and the composting facility in Jühnsdorf earn tipping fees of $20 € / \mathrm{Mg}$ FM input for the third-party management of green waste in the HTC-investor view of the rural-urban and rural HTC scenarios, respectively. 
While the HTC coal in the urban and rural-urban HTC scenarios is produced and fired by a single operator each, the rural HTC scenario comprises two separate operators for HTC-coal production (the composting facility in Jühnsdorf) and HTC-coal combustion (Vattenfall). Accordingly, the HTC-investor view differs from the life-cycle view in making the transaction explicit, i.e. in accounting for the revenues obtained by the composting facility in Jühnsdorf from the sale of HTC coal. We assume that the HTC-coal sales price in the HTC-investor view is determined by Vattenfall's marginal willingness to pay for substituting one unit of energy generated from hard coal at the Reuter West CHP plant by the same unit of energy generated from HTC coal. Thus, the maximum price Vattenfall would be willing to pay for HTC coal (including the HTC-coal transportation costs) is $21.81 € / \mathrm{MWh}$, i.e. the sum of the fuel costs $(18.33 € / \mathrm{MWh})$ and carbon costs $(3.47 € / \mathrm{MWh})$ incurred for hard-coal combustion (Table 16). Net of the HTC-coal transportation costs, this amounts to $18.51 € / \mathrm{Mg}$ FM input (Table 19), or $75.88 € / \mathrm{Mg}$ HTC coal (based on 0.244 Mg HTC coal/Mg FM input, Table 2) and 18.97 €/MWh (based on the usable energy from rural HTC coal, at a $92 \%$ DM content, of $0.976 \mathrm{MWh} / \mathrm{Mg}$ FM input, Table 3).

Turning to the reference scenarios, sales of electricity and heat from hard-coal combustion at the Reuter West CHP plant occur in all cases, except for the HTC-investor view in the urban and rural reference scenarios. As detailed in Table 16, electricity sales are rewarded with the EEX spot-market price of $28 € / M W h$ (EEX 2017a) and those of heat with the heat retail price of $30 € / \mathrm{MWh}$ (Gores et al. 2013: 23). The total amount of energy sold from hardcoal combustion is the same as that replaced by HTC-coal combustion (see Table 16). The revenues from biomass tipping fees in the life-cycle view are the same as in the HTC scenarios. In the HTC-investor view, tipping fees are only earned in the urban reference scenario, for the green waste dropped off at the $B S R$ recycling points. Finally, in the life-cycle view of the reference scenarios, revenues of $1.16 € / \mathrm{Mg} \mathrm{FM}$ input (urban reference scenario), $0.71 € / \mathrm{Mg} \mathrm{FM}$ input (rural-urban reference scenario), and $0.61 € / \mathrm{Mg} F M$ input (rural reference scenario) are generated for the sale of compost (Tables 20 to 22). They reflect the production costs for mineral fertilizers that are saved by the use of compost and are based on the assumption that farmers are willing to pay the same for compost as for the nutrient-equivalent amount of mineral fertilizers, after accounting for compost transportation costs. In 2016, the average nutrient value of compost reached 11.63 €/Mg compost (Bundesgütegemeinschaft Kompost 2017: 6).

As for the costs, the revenues for all the HTC and reference scenarios are summarized in Tables 17 to 22 .

\section{3) Social Life-Cycle Assessment}

In the SLCA, we add a social dimension to the LCC results along the entire cradle-to-grave life cycle, mainly by considering the social costs of carbon associated with the external effects of GHG emissions. The corresponding data to calculate the $N P V_{S L C A}$ are given in Tables 17 to 22 .

The social costs of carbon are monetized in the form of physical damage costs. According to Krewitt and Schlomann (2006: 1), the damage costs range from about 15-280 €/Mg $\mathrm{CO}_{2} \mathrm{e}$. In our analysis, we work with the value of $70 € / \mathrm{Mg} \mathrm{CO}_{2} \mathrm{e}$ as also suggested by Krewitt and Schlomann (2006: 1). As seen in Tables 17 to 22, the damage costs are applied to the life-cycle GHG emissions of all the HTC and reference scenarios. To avoid double-counting (cf. Swarr et al. 2011), the carbon costs already internalized in the reference scenarios of the LCC approach via the purchase of emission allowances for the combustion of hard coal are deducted from the SLCA cash flows (Tables 20 to 22).

Moreover, to correct for transfer payments borne by society (cf. Huppes et al. 2008), we replace the EEG remunerations earned for the sale of electricity from the newly built biomass 
CHP plant in the urban HTC scenario by the EEX electricity spot-market price of $28 € / \mathrm{MWh}$ (EEX 2017a).

\section{4) Carbon Abatement Costs}

The carbon abatement costs are based on the GHG emissions from the LCA (Table 12) and on (net) cost data derived from the life-cycle view of the LCC approach (Tables 17 to 22).

The modifications to the cash flows from the LCC approach used for the $A C$ calculation can be found in Tables 17 to 22. In particular, we do not take into account any carbon costs in the calculation of carbon abatement costs (cf. Marcantonini and Ellerman 2015). Moreover, the revenues between any pair of HTC and reference scenarios are usually equal and, thus, drop out of the $A C$ calculation. However, there are two exceptions. First, despite the same amount of usable energy in the urban HTC and reference scenarios, the respective quantities of heat and electricity are not identical. This is due to the differences in the thermal and electrical conversion efficiencies between the new biomass CHP plant in the urban HTC scenario and the Reuter West CHP plant in the urban reference scenario. Thus, the revenues from the sales of electricity and heat must be explicitly accounted for in the urban $A C$ calculation. Other than in the LCC approach, however, we value the sale of electricity in the urban HTC scenario at the EEX spot-market price of $28 € / M W h$ (EEX 2017a). Second, the revenues from the sale of compost must be considered since they occur only in the reference scenarios.

\section{4) Results and Discussion}

In this section, we present and discuss the results obtained from the life-cycle sustainability assessment (i.e. from the LCA, the LCC approach, and the SLCA) and from the calculation of carbon abatement costs.

\section{1) Life-Cycle Assessment}

Starting with the LCA results, Table 12 reveals that the three HTC scenarios are associated with relatively modest GHG emissions, $E_{H T C}$, in the range of $51.3-55.5 \mathrm{~kg} \mathrm{CO}_{2} \mathrm{e} / \mathrm{Mg}$ FM input, while the GHG emissions of the reference scenarios, $E_{\text {Reference, }}$ amount to $349.2-372.0 \mathrm{~kg} \mathrm{CO} \mathrm{CO}_{2} \mathrm{e} / \mathrm{Mg}$ FM input. The single most important driver of the GHG emissions in the reference scenarios is hard-coal combustion, with combustion-related emissions of 306.8-326.2 kg CO $2 \mathrm{e} / \mathrm{Mg} \mathrm{FM}$ input and pre-combustion emissions of 32.0-44.2 $\mathrm{kg} \mathrm{CO}_{2} \mathrm{e} / \mathrm{Mg} \mathrm{FM}$ input (Table 12). Moreover, the reference scenarios' emission savings from the use of compost as a soil amendment to replace mineral fertilizers are slightly outweighed by the $\mathrm{CH}_{4}$ and $\mathrm{N}_{2} \mathrm{O}$ emissions from composting occurring during the rotting process alongside the emissions from transports and auxiliary energy requirements (Table 12).

Assessed against the respective reference case (i.e. $E_{\text {Reference }}-E_{H T C}$ ), the HTC scenarios lead to substantial net GHG savings, largely driven by the substitution of hard coal by HTC coal (Table 12; Figure 5). More precisely, the net GHG savings potential of the urban HTC scenario reaches $301.6 \mathrm{~kg} \mathrm{CO} 2 \mathrm{e} / \mathrm{Mg}$ FM input, and the net GHG savings potentials of the ruralurban and rural HTC scenarios refer to $298.0 \mathrm{~kg} \mathrm{CO} 2 \mathrm{e} / \mathrm{Mg}$ FM input and $316.5 \mathrm{~kg} \mathrm{CO}_{2} \mathrm{e} / \mathrm{Mg}$ FM input, respectively (Table 12; Figure 5). Thus, the best result is achieved for the rural HTC scenario. In particular, it performs better than the rural-urban HTC scenario (the other scenario where the HTC coal is co-fired in the existing Reuter West CHP plant) since the rural HTC coal 
is entirely derived from low-moisture grass cuttings and, thus, has a higher energy content than the rural-urban HTC coal (Table 3), which allows it to substitute for a greater amount of hard coal. While the urban HTC coal, in turn, has the lowest energy content (Table 3), the favorable conversion efficiency of the new biomass CHP plant means that the urban HTC scenario saves nearly as many GHG emissions as the rural HTC scenario.

Combining each HTC scenario's net GHG savings potential (in $\mathrm{kg} \mathrm{CO}_{2} \mathrm{e} / \mathrm{Mg} \mathrm{FM}$ input) with the scenario's annual biomass input (Table 1), the annual GHG mitigation potential of HTC coal reaches 22,230 Mg CO $2 \mathrm{e} / \mathrm{a}$ in the urban scenario, 22,532 $\mathrm{Mg} \mathrm{CO}_{2} \mathrm{e} / \mathrm{a}$ in the ruralurban scenario, and 25,749 $\mathrm{Mg} \mathrm{CO}_{2} \mathrm{e} / \mathrm{a}$ in the rural scenario (Table 12). Thus, taken together, the three HTC scenarios can mitigate $70,511 \mathrm{Mg} \mathrm{CO}_{2}$ e per year.

Putting into perspective the aggregated GHG mitigation potential of the three HTC scenarios in the metropolitan region of Berlin, 70,511 $\mathrm{Mg} \mathrm{CO}_{2} \mathrm{e} / \mathrm{a}$ corresponds to about $1.6 \%$ of the GHG savings of 4.3 million $\mathrm{Mg} \mathrm{CO}_{2} \mathrm{e} / \mathrm{a}$ required to reduce Berlin's $\mathrm{GHG}$ emissions from the 2005 level of about 21.9 million $\mathrm{Mg} \mathrm{CO}_{2} \mathrm{e} / \mathrm{a}$ to the 2020 target of 17.6 million $\mathrm{Mg} \mathrm{CO}_{2} \mathrm{e} / \mathrm{a}$ (Suck et al. 2011: 1). The aggregated GHG mitigation potential of HTC coal is comparable to the $\mathrm{GHG}$ emission savings of $67,874 \mathrm{Mg} \mathrm{CO}_{2} \mathrm{e} / \mathrm{a}$ reached by third-party contracting to increase the energy efficiency of public buildings in Berlin (so-called energy savings partnerships) (Suck et al. 2011: 87). However, it is much smaller than many other mitigation measures. For example, the replacement of traditional boilers by small, decentral CHP stations could possibly save up to 280,000 $\mathrm{Mg} \mathrm{CO}_{2} \mathrm{e} / \mathrm{a}$ (Suck et al. 2011: 84). Even greater mitigation potentials could be achieved by modernization measures that improve the energy efficiency of private buildings (Suck et al. 2011).

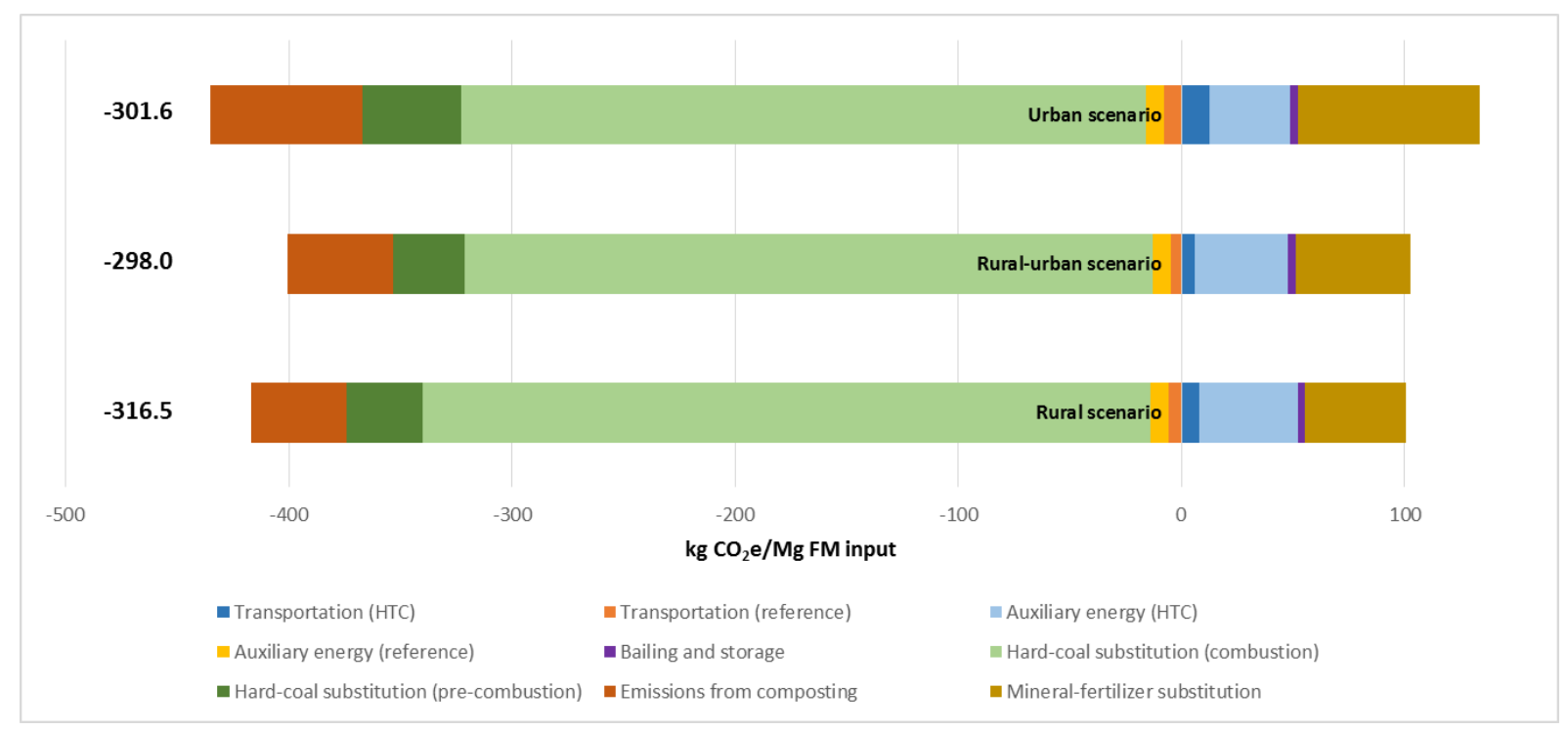

Figure 5: HTC Life-Cycle Emissions Net of Reference Emissions

Source: Table 12, with inverted signs for GHG emissions from the reference scenarios.

Notes: Each scenario is based on a different annual FM biomass input (Table 1). Values rounded.

\section{2) Life-Cycle Costing Approach}

A list of the costs and revenues entering the LCC approach (for both the life-cycle and the HTCinvestor views) can be found in Tables 17 to 19 for the HTC scenarios, and in Tables 20 to 22 for the reference cases. The corresponding $N P V_{L C C}$ and $N P V_{\text {investor }}$ are summarized in Table 23. 


\subsection{1) Life-Cycle View}

While all HTC scenarios are characterized by $N P V_{L C C}>0$, the $N P V_{L C C}$ of each HTC scenario is smaller than that of the respective reference scenario (Table 23). Thus, the HTC scenarios reach absolute profitability, but are unprofitable in relative terms.

The urban HTC scenario has the smallest $N P V_{L C C}$ of the three HTC scenarios (Table 23). While it profits from the higher EEG remunerations earned by HTC-coal mono-firing in the new biomass CHP plant, it is associated with greater capital-related costs due to the construction of the new biomass CHP plant (Figure 6). Moreover, the transportation costs of the urban HTC scenario are higher than in the other two HTC scenarios (Figure 6) since its logistics concept is more complex (Section 2.1).

It should be noted that the results obtained for the HTC scenarios and for the matched reference cases are highly sensitive to the tipping fees earned for the green waste dropped off at the biomass collection points. As can be seen in Figure 6 for the HTC scenarios, a reduction of the tipping fees below a certain threshold will render the HTC scenarios unprofitable in absolute terms. The same is true for the reference cases. However, the reference cases support lower tipping fees than the HTC scenarios before they become unprofitable (Tables 17 to 22). The sensitivity of the results to the tipping fees is a mirror image of the importance of feedstock costs found by Erlach et al. (2011) and Eberhardt et al. (2011).

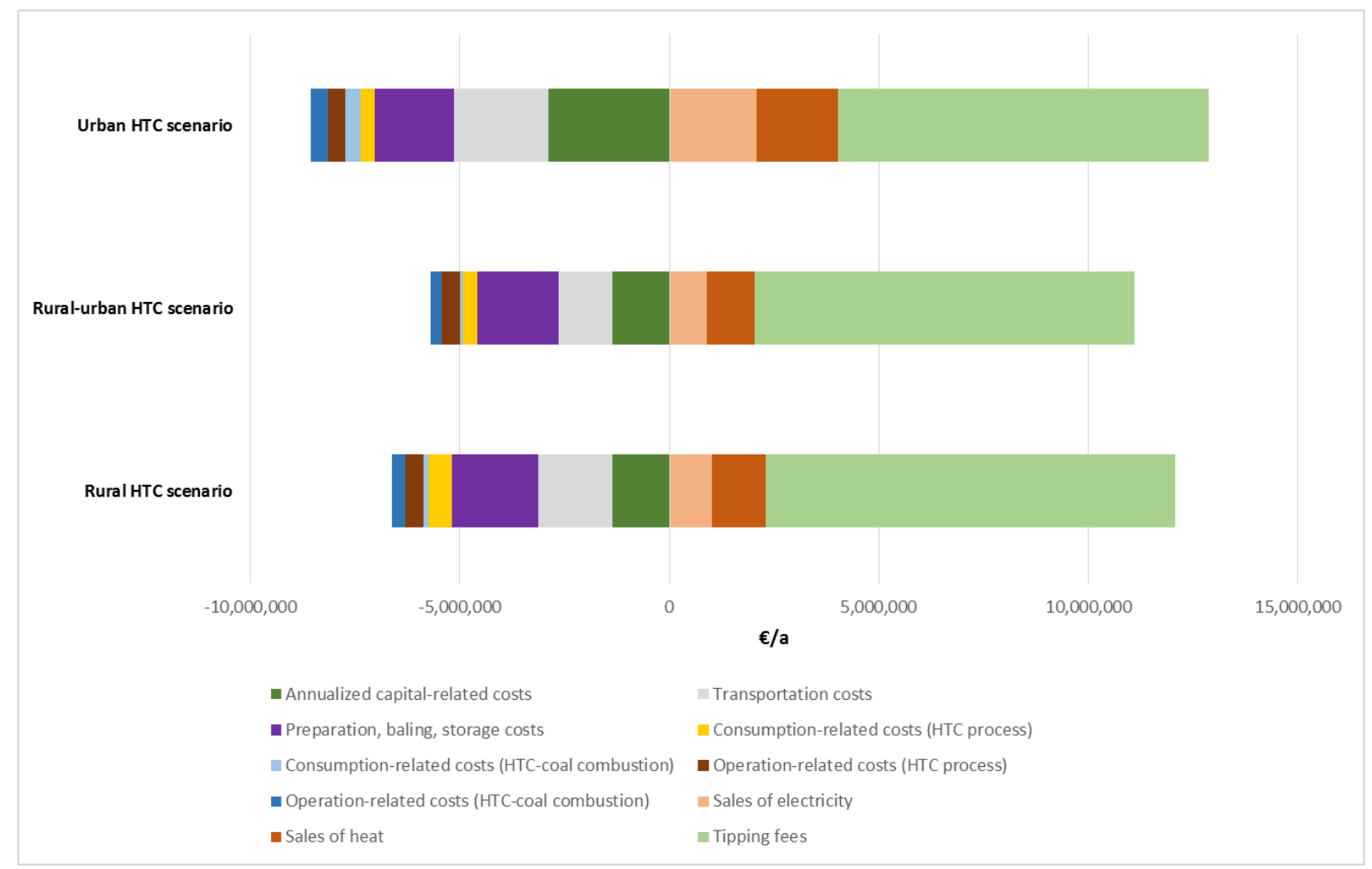

Figure 6: Annual Costs and Revenues in the HTC Scenarios' Life-Cycle View

Sources: Tables 17 to 19, where the capital-related costs are annualized analogously to equation (6).

\subsection{2) HTC-Investor View}

Turning to the HTC-investor view (i.e. the pure business standpoint of the waste-management company BSR in the urban scenario, the energy company Vattenfall in the rural-urban scenario, 
and the composting facility in Jühnsdorf in the rural scenario), the net present values in all HTC and reference scenarios drop below the respective net present values of the life-cycle view (Table 23). That is, $N P V_{\text {investor }}<N P V_{L C C}$. In the rural-urban and rural HTC scenarios, we even have $N P V_{\text {investor }}<0$. This means that both HTC scenarios are absolutely unprofitable for the respective HTC investor. In relative terms, the difference between the $N P V_{\text {investor }}$ of each HTC scenario and its reference case is more negative than the corresponding difference between the $N P V_{L C C}$ in the life-cycle view (Table 23). In other words, all the HTC scenarios in the HTCinvestor view become relatively more unprofitable than the respective reference cases. Thus, it is not worthwhile for the three potential HTC investors to alter their current activity in favor of an HTC system.

However, the results are highly dependent on the tipping fees. The main cause for the decrease in the HTC scenarios' NPVs from the life-cycle view to the HTC-investor view are the reduced tipping fees assumed for the third-party management of green waste (as opposed to the tipping fees earned for the green waste dropped off at the biomass collection points) (Tables 17 to 19). As can be easily seen from a comparison of the rural-urban (Tables 18 and 21) and rural (Tables 19 and 22) HTC and reference scenarios, for example, higher tipping fees earned by the respective HTC investor could render the rural-urban and rural HTC scenarios superior to their respective reference cases (which are unaffected by the tipping fees).

Moreover, the HTC-investor view of the rural HTC scenario, which separates HTC-coal production from HTC-coal combustion, makes explicit the discrepancy between the costs to produce HTC coal and the potential revenues from its sale. The maximum price Vattenfall would be willing to pay for HTC coal at a $92 \%$ DM content (net of transportation costs) amounts to $75.88 € / \mathrm{Mg}$ HTC coal (or 18.51 €/Mg FM input, $18.97 € / \mathrm{MWh}$ ) (Table 19; Section 3.2.2). However, the HTC-coal production costs for the composting facility in Jühnsdorf (net of the revenues from tipping fees for third-party management of green waste) stand at $151.2 € / \mathrm{Mg}$ HTC coal (or $36.9 € / \mathrm{Mg}$ FM input, $37.8 € / \mathrm{MWh}$ ) (Table 19). Thus, the net production costs are too high for HTC coal to compete with hard coal.

As further revealed by Tables 17 and 18, the net HTC-coal production costs in the urban and rural-urban HTC scenarios, respectively, reach $268.1 € / \mathrm{Mg}$ HTC coal (or $60.5 € / \mathrm{Mg}$ FM input, $52.5 € / \mathrm{MWh}$ ) and $141.3 € / \mathrm{Mg} \mathrm{HTC}$ coal (or 32.6 $€ / \mathrm{Mg}$ FM input, $35.3 € / \mathrm{MWh}$ ). Except for the urban HTC coal, the net HTC-coal production costs in our study are, thus, in line with Eberhardt et al. (2011), who find that the production costs of HTC coal from cereal straw range from $160.65-183.38 € / \mathrm{Mg}$ HTC coal, on a dry base. The higher net production costs for the urban HTC coal compared to the rural-urban and rural HTC coal are driven by the higher capital-related costs associated with the additional construction of a biomass CHP plant, the higher transportation costs due to the more complex logistics concept, and the lower share of third-party-managed green waste (Tables 17 to 19).

\section{3) Social Life-Cycle Assessment}

While Tables 17 to 22 contain a summary of the costs and revenues used in the SLCA, the $N P V_{S L C A}$ for all HTC and reference scenarios can be found in Table 23.

As a result of the application of damage costs, all the NPVs in the SLCA are lower than in the life-cycle view of the LCC approach, i.e. $N P V_{S L C A}<N P V_{L C C}$ for all HTC and reference scenarios (Table 23). However, the $N P V_{S L C A}$ remain positive. Due to the greater GHG emissions (Table 12), the NPVs of the reference cases are reduced more than the NPVs of the HTC scenarios, at least in the rural-urban and rural scenarios. In the urban HTC scenario, a relatively stronger reduction in the NPV is obtained due to the additional replacement of the EEG remuneration for electricity sales by the lower EEX electricity spot-market price (Table 17). 
Overall, the HTC scenarios are still unprofitable when compared to the respective reference scenarios (Table 23). However, at a social carbon price of $70 € / \mathrm{Mg} \mathrm{CO}_{2} \mathrm{e}$, relative profitability is nearly reached in the rural-urban and rural HTC scenarios (Table 23).

What is the carbon price at which the HTC scenarios would break even with the reference scenarios and start to become socially more desirable? This question can be answered by turning to the carbon abatement costs.

\section{4) Carbon Abatement Costs}

The carbon abatement costs, $A C$, associated with the switch from a given reference case to the corresponding HTC scenario are detailed in Table 24.

The urban scenario leads to carbon abatement costs of $162.7 € / \mathrm{Mg} \mathrm{CO}_{2} \mathrm{e}$, the rural-urban scenario to $74.1 € / \mathrm{Mg} \mathrm{CO}_{2} \mathrm{e}$, and the rural scenario to $75.2 € / \mathrm{Mg} \mathrm{CO}_{2} \mathrm{e}$ (Table 24). Thus, the rural-urban and rural HTC scenarios offer the most cost-effective ways to reduce GHG emissions among the three HTC scenarios. Since the $A C$ calculation abstracts from any carbon costs and considers the EEX electricity spot-market price for electricity sales in the urban HTC scenario rather than the higher EEG remuneration (Section 3.4), the carbon abatement costs coincide with the carbon price necessary to render the HTC scenarios equally profitable like their reference cases in the SLCA. Being associated with carbon abatement costs just slightly above the social costs of carbon assumed in the SLCA $\left(70 € / \mathrm{Mg} \mathrm{CO}_{2} \mathrm{e}\right)$, thus, explains why the rural-urban and rural HTC scenarios nearly reach profit equality with their reference scenarios in the SLCA (Section 4.3).

As illustrated in Figure 7, which disaggregates the $A C$ into their single cost components, the move from the reference scenarios to the HTC scenarios increases the capital-related costs and the transportation costs. Unlike the urban HTC scenario, however, the rural-urban and rural HTC scenarios profit from the possibility of co-firing the HTC coal in an existing CHP plant, which reduces their capital requirements. Moreover, they apply simpler logistics concepts than the urban HTC scenario (Section 2.1) and are, thus, associated with lower transportation costs. A major driver of the $A C$ in all three scenarios are the costs incurred for biomass preparation, baling, and storage, while forgone revenues (mainly from the sale of compost) are the smallest contributor to the carbon abatement costs. A cost-reducing component of the $A C$ are the lower consumption- and operation-related costs of the HTC scenarios compared to their reference cases. ${ }^{19}$ The reduction in the consumption-related costs is lowest in the rural scenario since it misses the possibility of electricity self-supply for HTC-coal drying.

The carbon abatement costs in the rural-urban and rural scenarios compare well with those obtained by Erlach et al. (2011) for HTC coal from biodegradable waste used to substitute for bituminous coal, $81.28 €_{2009} / \mathrm{Mg} \mathrm{CO}_{2} \mathrm{e}$. While the $A C$ in the urban scenario are higher, they come relatively close to the $115.75-135.14 €_{2009} / \mathrm{Mg} \mathrm{CO}_{2} \mathrm{e}$ derived for HTC coal from poplar wood chips (Erlach et al. 2011). ${ }^{20}$ Moreover, all scenarios' $A C$ are lower than the $190 € / \mathrm{Mg}$ $\mathrm{CO}_{2} \mathrm{e}$ associated with biogas generated from biodegradable waste to replace electricity and heat from a modern coal power plant (Hennig and Gawor 2012: Figure 8). The carbon abatement costs for the other bioenergy pathways in Hennig and Gawor (2012: Figure 8) reach even 240$510 € / \mathrm{Mg} \mathrm{CO}_{2} \mathrm{e}$. Similarly, the carbon abatement costs for biogas from corn (maize) and from

\footnotetext{
${ }^{19}$ However, other than in the HTC scenarios, the consumption- and operation-related costs in the reference scenarios include the costs for biomass preparation (Section 3.2.1).

${ }^{20}$ While not directly comparable to the feedstocks and regional setting used in our study, the carbon abatement costs for HTC coal from palm-oil empty fruit bunches (EFBs) - produced in South-East Asia and shipped to Europe to replace bituminous coal - range from 60.4-79.8 $€_{2010} / \mathrm{Mg} \mathrm{CO}_{2} \mathrm{e}$ if the EFBs are diverted from mulching, and from 18.6-24.6 $€_{2010} / \mathrm{Mg} \mathrm{CO}_{2} \mathrm{e}$ if HTC avoids EFB dumping (Stemann, Erlach, and Ziegler 2013).
} 
mixtures of corn and cattle slurry in Brandenburg, Germany, range from $288-674 € / \mathrm{Mg} \mathrm{CO}_{2} \mathrm{e}$ without accounting for opportunity costs related to land use; if considering opportunity costs, then the carbon abatement costs amount to 459-1,135 €/Mg $\mathrm{CO}_{2} \mathrm{e}$ (Scholz et al. 2011).

Compared to non-biomass sources of renewable energy, the $A C$ in our study fall between the carbon abatement costs of wind and solar energy in Germany. For example, Marcantonini and Ellerman (2015: Table 8) find that the 2006-2010 average implicit carbon price, which is largely equivalent to carbon abatement costs, amounted to $57 €_{2011} / \mathrm{Mg} \mathrm{CO}_{2}$ for wind energy and $552 €_{2011} / \mathrm{Mg} \mathrm{CO}_{2}$ for solar energy - if remunerations to generators in the form of feed-in tariffs granted by the EEG are taken into account. ${ }^{21}$ Even if learning effects are included, the average implicit carbon prices still stand at $48 €_{2011} / \mathrm{Mg} \mathrm{CO}_{2}$ for wind and $306 €_{2011} / \mathrm{Mg} \mathrm{CO}_{2}$ for solar energy (Marcantonini and Ellerman 2015: 228). Hence, HTC exhibits even lower carbon abatement costs than solar energy, a more established technology, in the early years of its public promotion. However, note that the carbon abatement costs for solar energy should be considered as an upper bound since the feed-in tariffs for solar energy have been drastically reduced since 2012, albeit only for new installations (Marcantonini and Ellerman 2015).

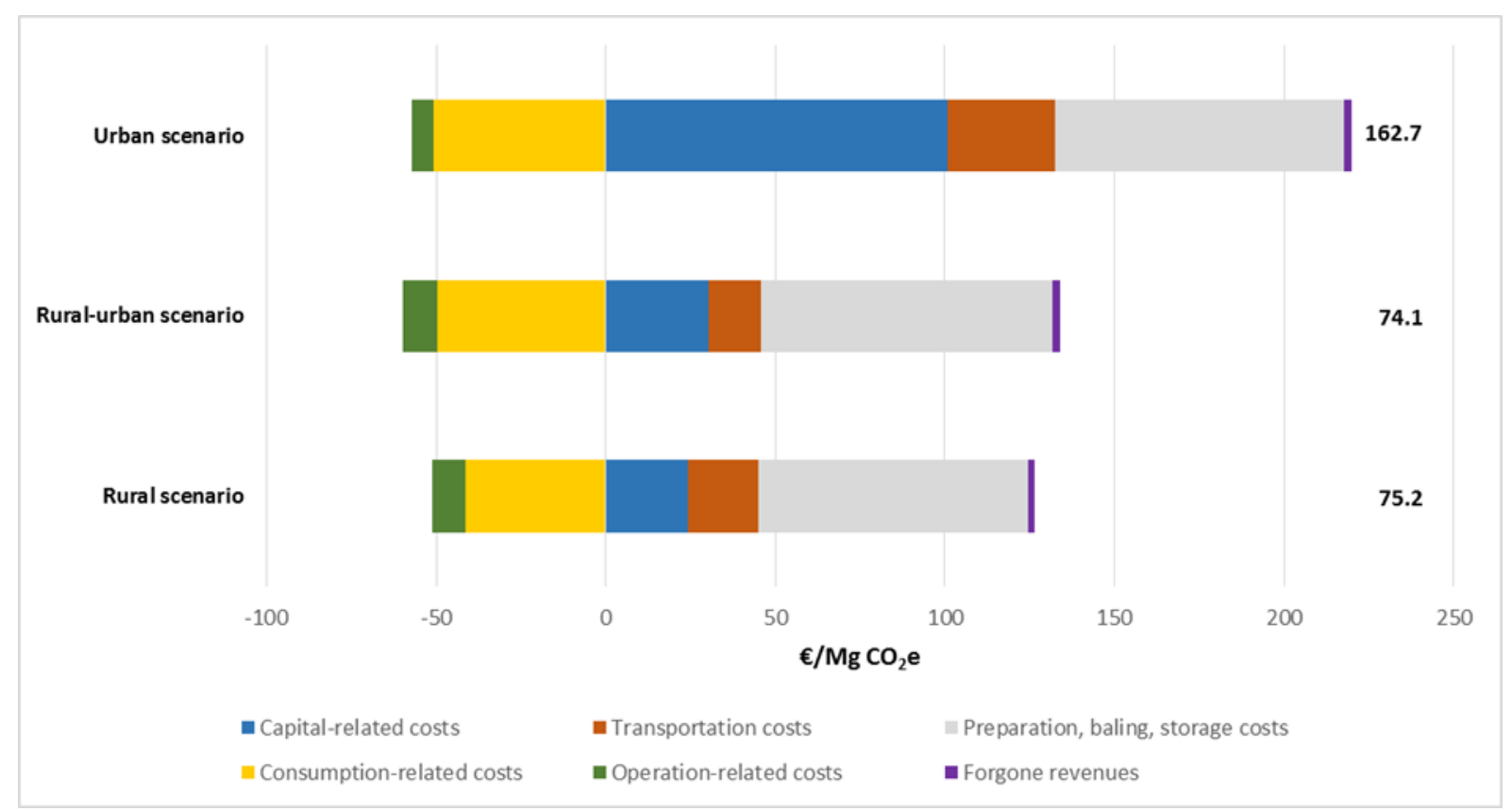

Figure 7: Breakdown of Carbon Abatement Costs

Sources: For each cost category, the values refer to the difference in costs between each HTC and reference scenario in $€ /$ a as obtained from column 5 of Tables 17 to 22, divided by the respective difference in emissions, $E_{\text {Reference }}-E_{H T C}$, in $\mathrm{Mg} \mathrm{CO}_{2} \mathrm{e} / \mathrm{a}$ from Table 12.

Note: The capital-related costs are annualized analogously to equation (6). Values rounded.

\section{5) Conclusions and Policy Implications}

In this paper, we provide a comprehensive environmental and economic assessment of three scenarios for the production of HTC coal from leaves and grass cuttings in the metropolitan

\footnotetext{
${ }^{21}$ In our study, EEG remunerations are only relevant for electricity sales in the urban HTC scenario. In calculating the $A C$, we account for the corresponding costs to society by only deducting the revenues from electricity sales associated with the EEX electricity spot-market price (Section 3.4).
} 
region of Berlin, Germany. The green waste is redirected from composting and the subsequent soil application of the compost to substitute for mineral fertilizers. The HTC coal, in turn, replaces hard coal in the generation of electricity and heat.

Although we provide a case study for a relatively narrow region, the comparison across the different HTC scenarios allows us to draw some general conclusions. First, the location of the HTC plants and the logistics concepts are crucial determinants for the profitability of HTC systems. Major trade-offs for the co-location of an HTC plant at a power plant occur between potential cost reductions due to easy access to energy and/or opportunities for HTC-coal combustion, on the one hand, and potential cost increases due to greater biomass transport distances and limited on-site storage capacities, on the other hand. Second, the use of an existing coal-fired CHP plant for the co-firing of HTC coal is less expensive than the construction of a new biomass CHP plant for HTC-coal mono-firing, even if the new plant has a greater energyconversion efficiency. This shows, third, that the most useful application of HTC coal might be as a bridging technology. Offering a flexible and demand-oriented energy supply, HTC-coal co-firing could ensure high utilization rates of existing conventional power plants without causing further GHG emissions. When co-fired in an efficient CHP plant, the overall system efficiency of HTC coal could reach more than 60\% (Section 3.1.2), which is well above that of most fossil-fuel power plants in Germany (cf. Hobohm et al. 2011: 66).

Judged from the relative unprofitability of the HTC scenarios compared to their reference cases, as obtained from the LCC approach (both for the life-cycle and HTC-investor views), the diversion of leaves and grass cuttings from composting into HTC-coal production is not economically viable under the current conditions. With a positive GHG mitigation potential, increased profitability in the SLCA, and carbon abatement costs within a reasonable range, however, public support of HTC-coal production could be justified.

To this end, the rural-urban and rural HTC scenarios are the most interesting cases. On the one hand, the results from the SLCA and abatement-cost calculation show that both scenarios can become advantageous if damage costs are taken into account. More precisely, they become preferable over their respective reference cases at carbon costs of slightly above $75 € / \mathrm{Mg} \mathrm{CO}_{2} \mathrm{e}$. Thus, the SLCA and abatement-cost calculation suggest increased carbon prices as policy instrument, such as an increase in the price of emission allowances in the EU ETS, or a floor price for carbon emissions as currently discussed in Europe (cf. Wehrmann 2017). On the other hand, the NPVs of the rural-urban and rural HTC scenarios in the HTC-investor view are negative. While an increase in the carbon price raises the willingness to pay for HTC coal in the rural HTC scenario and, thus, might turn the NPV in the HTC-investor view positive and greater than the corresponding NPV of the rural reference scenario, such a change in sign will not occur in the rural-urban HTC scenario. This means that the potential investor into the HTC facility in the rural-urban scenario will have no incentive to implement the new technology, even if the carbon price rises. Other support measures would be required instead, such as higher rewards for renewable-energy sales in terms of a feed-in tariff for solid-biomass combustion or for co-firing applications; however, with the caveat that properly accounting for these subsidies would increase the carbon abatement costs (cf. Marcantonini and Ellerman 2015). Thus, in terms of policy implications, we find that the right choice of public support requires a thorough analysis of the incentives of each single actor along the entire life cycle in order to identify and correctly target the bottlenecks for the adoption of mitigation technologies.

\section{Acknowledgements}

We are grateful to Wolfgang Bokelmann, Philip Grundmann, Andreas Meyer-Aurich, and seminar participants at DIW Berlin and Humboldt University Berlin for their scientific support. We further thank Adam M. Lederer for language-editing. This paper is based on the master thesis "Hydrothermal carbonization of green wastes: A techno- 
economic assessment of sustainable organic waste management in the metropolitan region of Berlin," submitted by Jakob Medick to Humboldt University Berlin in 2014. He thanks SunCoal Industries GmbH for their close cooperation and generous data provision, as well as Berliner Stadtreinigung (BSR), Vattenfall GmbH, and the engineering office Ingenieurconsulting Umwelt und Bau (ICU) for their intellectual support and exchange. Note that the provided case study is hypothetical and unrelated to any current business activities of the firms used in the scenarios. This work was funded by the Leibniz Association (SAW-2012-ATB-3).

\section{References}

Amt für Statistik Berlin-Brandenburg. 2016. Statistischer Bericht E IV 4 - j / 13. Energie- und $\mathrm{CO}_{2}-$ Bilanz in Berlin 2013. Potsdam. Retrieved on 8 November 2016 from: https://www.statistik-berlinbrandenburg.de/publikationen/stat_berichte/2016/SB_E04-04-00_2013j01_BE.pdf

APM. 2017. Annahmegebühren Wertstoffhöfe. Abfallwirtschaft Potsdam-Mittelmark GmbH (APM). Retrieved on 26 June 2017 from: https://www.apm-niemegk.de/wertstoffhoefe-annahmestellen-lkpm/wertstoffhoefeannahmegeb

Berge, N. D., K. S. Ro, J. Mao, J. R. V. Flora, M. A. Chappell, and S. Bae. 2011. Hydrothermal carbonization of municipal waste streams. Environmental Science \& Technology 45(13): 5696-5703.

Bergius, F. 1913. Die Anwendung hoher Drucke bei chemischen Vorgängen und eine Nachbildung des Entstehungsprozesses der Steinkohle. Knapp, Halle (Saale).

BMWi and BMU (eds). 2010. Energiekonzept für eine umweltschonende, zuverlässige und bezahlbare Energieversorgung. Bundesministerium für Wirtschaft und Technologie (BMWi), Bundesministerium für Umwelt, Naturschutz und Reaktorsicherheit (BMU).

Brunstermann, R. 2007. Übung biologische Abfallbehandlung (Teil 1). University Duisburg/Essen. Retrieved on 12 January 2013 from: https://www.uni-due.de/imperia/md/content/abfall/_bungbiologie1bsc2007.pdf

BSR. 2017. Laub- und Gartenabfälle richtig entsorgen. Berliner Stadtreinigung (BSR). Retrieved on 26 June 2017 from: https://www.bsr.de/gartenabfaelle-23508.php

Bundesgesetzblatt. 2016. Gesetz zur Einführung von Ausschreibungen für Strom aus erneuerbaren Energien und $z u$ weiteren Änderungen des Rechts der erneuerbaren Energien. Vom 13. Oktober 2016 - Artikel 1: Änderung des Erneuerbare-Energien-Gesetzes. Bundesgesetzblatt 2016 I 49: 2258-2310.

Bundesgütegemeinschaft Kompost (ed). 2017. BGK-Statistik: Verwertung von Bioabfällen 2016. Humuswirtschaft \& Kompost aktuell Q1: 4-6.

Cherubini, F. 2010. GHG balances of bioenergy systems - Overview of key steps in the production chain and methodological concerns. Renewable Energy 35(7): 1565-1573.

Eberhardt, G., M. Odening, H. Lotze-Campen, B. Erlach, S. Rolinski, P. Rothe, and B. Wirth. 2011. Rentabilität der Hydrothermalen Karbonisierung unter besonderer Berücksichtigung von Transportkosten. Berichte über Landwirtschaft 89(3): 400-424.

EEX. 2017a. Electricity spot-market data (auction; Phelix day base). European Energy Exchange AG Leipzig (EEX). Retrieved on 8 June 2017 from: http://www.eex.com/de/

EEX. 2017b. EU Emission Allowances: Primary market auction; Germany. European Energy Exchange AG Leipzig (EEX). Retrieved on 8 June 2017 from: http://www.eex.com/de/

Eltrop, L., K. Raab, H. Hartmann, S. Schneider, G. Schröder, J. Fischer, B. Jahraus, and P. Heinrich. 2005. Leitfaden Bioenergie. Planung, Betrieb und Wirtschaftlichkeit von Bioenergieanlagen. Gülzow: Fachagentur Nachwachsende Rohstoffe e. V. (FNR).

Erlach, B., B. Wirth, and G. Tsatsaronis. 2011. Co-production of electricity, heat and biocoal pellets from biomass: A techno-economic comparison with wood pelletizing. Proceedings of the World Renewable Energy Congress 2011, Linköping, Sweden, May 8-13, 2011: 508-515.

Federal Ministry for Economic Affairs and Energy. 2017. Development of renewable energy sources in Germany 2016. Charts and figures based on statistical data from the Working Group on Renewable Energy-Statistics (AGEE-Stat), as at February 2017. Retrieved on 6 August 2017 from: http://www.erneuerbare-energien.de/EE/Redaktion/DE/Downloads/development-of-renewable-energysources-in-germany-2016.pdf? blob=publicationFile \&v=14

Fritsche, U. R. and L. Rausch. 2008. Bestimmung spezifischer Treibhausgas-Emissionsfaktoren für Fernwärme. Climate Change 08/2008. Dessau-Roßlau: Umweltbundesamt (UBA).

Funke, A. and F. Ziegler. 2010. Hydrothermal carbonization of biomass: A summary and discussion of chemical mechanisms for process engineering. Biofuels, Bioproducts \& Biorefining 4(2): 160-177.

Gores, S., R. O. Harthan, H. Hermann, C. Loreck, and F. C. Matthes. 2013. Perspektiven der Kraft-WärmeKopplung im Rahmen der Energiewende. Berlin/Darmstadt/Freiburg: Öko-Institut e.V. 
Hennig, C. and M. Gawor. 2012. Bioenergy production and use: Comparative analysis of the economic and environmental effects. Energy Conversion and Management 63: 130-137.

Hobohm, J., M. Koepp, L. Krampe, S. Mellahn, F. Peter, and F. Sakowski. 2011. Bedeutung der Braunkohle in Ostdeutschland. Report commissioned by the Vattenfall Europe AG. Berlin: Prognos AG.

Huppes, G., A. Ciroth, K. Lichtenvort, G. Rebitzer, W.-P. Schmidt, and S. Seuring. 2008. Modelling for life cycle costing. In: Hunkeler, D., K. Lichtenvort, and G. Rebitzer (eds). Environmental life cycle costing. Boca Raton, CRC Press: 17-34.

ICU. 2011. Hochwertige und klimaschonende Verwertung von Mähgut und Laub im Land Berlin. Ingenieurconsulting Umwelt und $\mathrm{Bau}$ (ICU) in cooperation with F. Riesbeck. Final report for Senatsverwaltung für Gesundheit, Umwelt und Verbraucherschutz, Berlin. Retrieved on 7 August 2017 from: http://www.berlin.de/senuvk/umwelt/abfallwirtschaft/downloads/biomasse/studie_maehgut.pdf

ICU. Unpublished data. Provided by Ulrich Wiegel, Ingenieurconsulting Umwelt und Bau (ICU).

ISO. 2006. Environmental management: Life cycle assessment - Requirements and guidelines (ISO 14044:2006). International Organization for Standardization (ISO). Dublin: National Standards Authority of Ireland.

KfW. 2017. Konditionenübersicht für Endkreditnehmer. Retrieved on 24 August 2017 from: https://www.kfwformularsammlung.de/KonditionenanzeigerINet/KonditionenAnzeiger?ProgrammNameNr=270

Kloepffer, W. 2008. Life cycle sustainability assessment of products. International Journal of Life Cycle Assessment 13(2): 89-95.

Knappe, F., R. Vogt, S. Lazar, and S. Höke. 2012. Optimierung der Verwertung organischer Abfälle. Texte 31/2012. Dessau-Roßlau: Umweltbundesamt (UBA).

Kranert, M. and K. Cord-Landwehr (eds). 2010. Einführung in die Abfallwirtschaft. Wiesbaden: Vieweg + Teubner. Krewitt, W. and B. Schlomann. 2006. Externe Kosten der Stromerzeugung aus erneuerbaren Energien im Vergleich zur Stromerzeugung aus fossilen Energieträgern. Stuttgart/Karlsruhe: Deutsches Zentrum für Luft- und Raumfahrt (DLR)/Fraunhofer Institut für System- und Innovationsforschung (ISI).

Leible, L., A. Arlt, B. Fürniß, S. Kälber, G. Kappler, S. Lange, E. Nieke, C. Rösch, and D. Wintzer. 2003. Energie aus biogenen Rest- und Abfallstoffen: Bereitstellung und energetische Nutzung organischer Rest- und Abfallstoffe sowie Nebenprodukte als Einkommensalternative für die Land- und Forstwirtschaft Möglichkeiten, Chancen und Ziele. Wissenschaftliche Berichte FZKA 6882. Karlsruhe: Forschungszentrum Karlsruhe.

Libra, J. A., K. S. Ro, C. Kammann, A. Funke, N. D. Berge, Y. Neubauer, M.-M. Titirici, C. Fühner, O. Bens, J. Kern, and K.-H. Emmerich. 2011. Hydrothermal carbonization of biomass residuals: A comparative review of the chemistry, processes and applications of wet and dry pyrolysis. Biofuels 2(1): 89-124.

Liu, Z., A. Quek, S. K. Hoekman, and R. Balasubramanian. 2013. Production of solid biochar fuel from waste biomass by hydrothermal carbonization. Fuel 103: 943-949.

McKinsey. 2009. Pathways to a low-carbon economy: Version 2 of the global greenhouse gas abatement cost curve. McKinsey \& Company.

Marcantonini, C. and A. D. Ellerman. 2015. The implicit carbon price of renewable energy incentives in Germany. Energy Journal 36(4): 205-239.

Neuhoff, K., J. Diekmann, F. Kunz, S. Rüster, W.-P. Schill, and S. Schwenen. 2016. A coordinated strategic reserve to safeguard the European energy transition. Utilities Policy 41: 252-263.

NSW Department of Environment and Conservation. 2007. Life cycle inventory and life cycle assessment for windrow composting systems. Parramatta: New South Wales (NSW) Department of Environment and Conservation.

Obernberger, I. and G. Thek. 2004. Techno-economic evaluation of selected decentralised CHP applications based on biomass combustion in IEA partner countries. Final paper. Graz: BIOS Bioenergiesysteme GmbH.

Oliveira, I., D. Blöhse, and H.-G. Ramke. 2013. Hydrothermal carbonization of agricultural residues. Bioresource Technology 142: 138-146.

Prochnow, A., M. Heiermann, M. Plöchl, B. Linke, C. Idler, T. Amon, and P. J. Hobbs. 2009. Bioenergy from permanent grassland - A review: 1. Biogas. Bioresource Technology 100(21): 4931-4944.

Ramke, H.-G., D. Blöhse, and H.-J. Lehmann. 2012. Wissenschaftlich-technische Grundlagen der Hydrothermalen Carbonisierung organischer Siedlungsabfälle. Müll und Abfall 9: 476-483.

Rehl, T. and J. Müller. 2013. $\mathrm{CO}_{2}$ abatement costs of greenhouse gas (GHG) mitigation by different biogas conversion pathways. Journal of Environmental Management 114: 13-25.

Reibe, K., C.-L. Roß, and F. Ellmer. 2015. Hydro-/Biochar application to sandy soils: Impact on yield components and nutrients of spring wheat in pots. Archives of Agronomy and Soil Science 61(8): 1055-1060. 
Rettenberger, G., S. Urban-Kiss, R. Schneider, J. Müsken, and G. Kruse. 2012. Handbuch Bioabfallbehandlung: Erfassung des Anlagenbestands Bioabfallbehandlung. Texte 54/2012. Dessau: Umweltbundesamt.

Reza, M. T., J. Andert, B. Wirth, D. Busch, J. Pielert, J. G. Lynam, and J. Mumme. 2014. Hydrothermal carbonization of biomass for energy and crop production. Applied Bioenergy 1(1): 11-29.

Roberts, K. G., B. A. Gloy, S. Joseph, N. R. Scott, and J. Lehmann. 2010. Life cycle assessment of biochar systems: Estimating the energetic, economic, and climate change potential. Environmental Science \& Technology 44(2): 827-833.

Rosegrant, M. W. and S. Msangi. 2014. Consensus and contention in the food-versus-fuel debate. Annual Review of Environment and Resources 39: 271-294.

Sänger, A., K. Reibe, J. Mumme, M. Kaupenjohann, F. Ellmer, C.-L. Roß, and A. Meyer-Aurich. 2017. Biochar application to sandy soil: Effects of different biochars and $\mathrm{N}$ fertilization on crop yields in a 3-year field experiment. Archives of Agronomy and Soil Science 63(2): 213-229.

Schill, W.-P. 2014. Residual load, renewable surplus generation and storage requirements in Germany. Energy Policy 73: 65-79.

Schill, W.-P. and A. Zerrahn. 2017. Long-run power storage requirements for high shares of renewables: Results and sensitivities. Renewable and Sustainable Energy Reviews (article in press).

Scholz, L., A. Meyer-Aurich, and D. Kirschke. 2011. Greenhouse gas mitigation potential and mitigation costs of biogas production in Brandenburg, Germany. AgBioForum 14(3): 133-141.

Schwilling, T., H. Mehner, B. Bruchmann, and H. Edel. 2011. Abfallwirtschaftskonzept für das Land Berlin: Planungszeitraum 2010 bis 2020. Senatsverwaltung für Gesundheit, Umwelt und Verbraucherschutz, Berlin.

Searchinger, T. D., S. P. Hamburg, J. Melillo, W. Chameides, P. Havlik, D. M. Kammen, G. E. Likens, R. N. Lubowski, M. Obersteiner, M. Oppenheimer, G. P. Robertson, W. H. Schlesinger, and G. D. Tilman. 2009. Fixing a critical climate accounting error. Science 326(5952): 527-528.

SenGUV and BSR. 2011. Abschlussbericht zur Kooperationsvereinbarung im Rahmen des Landesenergieprogramms Berlin 2006-2010, des Luftreinhalteplans 2005-2010 sowie des Abfallwirtschaftskonzepts 20052015 zwischen dem Land Berlin, Senatsverwaltung für Gesundheit, Umwelt und Verbraucherschutz. (SenGUV), und den Berliner Stadtreinigungsbetrieben (BSR). Berlin, 23 August 2011. Retrieved on 7 August 2017 from:

http://docplayer.org/9360684-Abschlussbericht-zur-kooperationsvereinbarung-im-rahmen-deslandesenergieprogramms-berlin-2006-2010-des-luftreinhalteplans-2005-2010.html

Slade, R., R. Saunders, R. Gross, and A. Bauen. 2011. Energy from biomass: The size of the global resource. Imperial College Centre for Energy Policy and Technology and UK Energy Research Centre, London.

Statista. 2017a. Industriestrompreise in Deutschland in den Jahren 2000 bis 2016 (in Euro-Cent pro Kilowattstunde). Retrieved on 8 June 2017 from:

https://de.statista.com/statistik/daten/studie/155964/umfrage/entwicklung-der-industriestrompreise-indeutschland-seit-1995/

Statista. 2017b. Durchschnittlicher Preis für einen Liter Diesel in Deutschland in den Monaten April 2016 bis April 2017 (in Cent). Retrieved on 8 June 2017 from:

https://de.statista.com/statistik/daten/studie/1691/umfrage/preis-fuer-einen-liter-dieselmonatsdurchschnittswerte/

Statistisches Bundesamt. 2017a. Preise: Daten zur Energiepreisentwicklung. Lange Reihen von Januar 2000 bis April 2017. Wiesbaden. Retrieved on 8 June 2017 from:

https://www.destatis.de/DE/Publikationen/Thematisch/Preise/Energiepreise/Energiepreisentwicklung.htm 1;jsessionid=42EC555F1F12E7D7E3A574D2D3A3FAB6.cae4

Statistisches Bundesamt. 2017b. Entgelt für die Trinkwasserversorgung privater Haushalte nach Bundesländern. Wiesbaden. Retrieved on 8 June 2017 from:

https://www.destatis.de/DE/ZahlenFakten/GesamtwirtschaftUmwelt/Umwelt/UmweltstatistischeErhebun gen/Wasserwirtschaft/Wasserwirtschaft.html

Stemann, J., B. Erlach, and F. Ziegler. 2013. Hydrothermal carbonisation of empty palm oil fruit bunches: Laboratory trials, plant simulation carbon avoidance, and economic feasibility. Waste and Biomass Valorization 4(3): 441-454.

Stemann, J., A. Putschew, and F. Ziegler. 2013. Hydrothermal carbonization: Process water characterization and effects of water recirculation. Bioresource Technology 143: 139-146.

Suck, A., A. Wetzel, B. Lüdecke, A. Weiland-Wascher, L. Dittmann, A. Aretz, E. Dunkelberg, B. Hirschl, A. Neumann, and J. Weiß. 2011. Energiekonzept 2020. Berlin: Land Berlin.

SunCoal. 2012. SunCoal Industries - Business Model SCI-2400 Serie. Internal data sheet received from SunCoal Industries GmbH (SunCoal) via email correspondence on 30 November 2012. 
Swarr, T. E., D. Hunkeler, W. Klöpffer, H.-L. Pesonen, A. Ciroth, A. C. Brent, and R. Pagan. 2011. Environmental life-cycle costing: A code of practice. International Journal of Life Cycle Assessment 16(5): 389-391.

Titirici, M.-M., A. Thomas, and M. Antonietti. 2007. Back in the black: Hydrothermal carbonization of plant material as an efficient chemical process to treat the $\mathrm{CO}_{2}$ problem? New Journal of Chemistry 31(6): 787789.

Valdivia, S., C. M. L. Ugaya, J. Hildenbrand, M. Traverso, B. Mazijn, and G. Sonnemann. 2012. A UNEP/SETAC approach towards a life cycle sustainability assessment - Our contribution to Rio+20. International Journal of Life Cycle Assessment 18 (9): 1673-1685.

van Haaren, R., N. J. Themelis, and M. Barlaz. 2010. LCA comparison of windrow composting of yard wastes with use as alternative daily cover (ADC). Waste Management 30(12): 2649-2656.

Vattenfall. 2017. Information on Reuter West CHP plant and its history. Retrieved on 20 June 2017 from: http://powerplants.vattenfall.com/reuter-west

Vogt, R., H. Fehrenbach, U. Wiegel, and K. Ebert. 2012. Maßnahmenplan zur Umsetzung einer vorbildhaften klimafreundlichen Abfallentsorgung im Land Berlin. Heidelberg: Institut für Energie- und Umweltforschung Heidelberg GmbH (ifeu).

Wehrmann, B. 2017. German carbon tax most efficient way to meet climate goals -study. Clean Energy Wire (CLEW). Retrieved on 26 August 2017 from: https://www.cleanenergywire.org/news/german-carbon-taxmost-efficient-way-meet-climate-goals-study

Wikipedia. 2017. Heizkraftwerk Reuter West. Retrieved on 20 June 2017 from: https://de.wikipedia.org/wiki/Heizkraftwerk_Reuter_West

Wirth, B., J. Mumme, and B. Erlach. 2012. Anaerobic treatment of waste water derived from hydrothermal carbonization. Proceedings of the 20 th European Biomass Conference and Exhibition, 18-22 June 2012, Milan, Italy: 683-692.

Zentner, A. 2012. Havelland-Fläming_Potenziale auf Gemeindeebene_spezifische Mengen_IAA_26 11 2012.xlsx. Unpublished data. Institut für Abfallwirtschaft und Altlasten (IAA), Technische Universität Dresden.

Zentner, A. 2013. EUDYSÉ - Globalanalyse Havelland Fläming. Themenfeld Stoffströme. Institut für Abfallwirtschaft und Altlasten (IAA), Technische Universität Dresden. 


\section{Appendix}

Table 1: Biomass Potentials of Leaves and Grass Cuttings and their Scenario Allocation

\begin{tabular}{|c|c|c|c|c|c|c|c|c|c|c|c|c|}
\hline & $\begin{array}{l}\text { Collection } \\
\text { authority }\end{array}$ & \multicolumn{2}{|c|}{$\begin{array}{l}\text { Biomass } \\
\text { potentials }\end{array}$} & Total & \multicolumn{2}{|c|}{$\begin{array}{c}\text { Scenario } \\
\text { allocation of } \\
\text { biomass } \\
\text { potentials } \\
\mathrm{Mg} \mathrm{FM} / \mathrm{a}\end{array}$} & 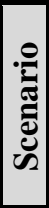 & \multicolumn{5}{|c|}{$\begin{array}{l}\text { Scenario allocation of biomass potentials } \\
\text { (subject to each scenario's HTC capacity } \\
\text { of } 55,000 \mathrm{Mg} \mathrm{FM} \text { prep/a) } \\
\mathrm{Mg} \mathrm{FM} / \mathrm{a}\end{array}$} \\
\hline \multirow{6}{*}{ 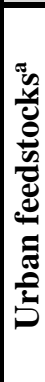 } & Berliner & Leaves: & 48,108 & \multirow{6}{*}{$\begin{array}{l}\text { 120,609 } \\
\text { Leaves: } \\
72,251 \\
\text { Grass: } \\
48,358\end{array}$} & \multirow{4}{*}{$\begin{array}{l}\text { Leaves: } \\
\text { Grass: }\end{array}$} & \multirow{4}{*}{$\begin{array}{l}61,242 \\
32,496\end{array}$} & \multirow{4}{*}{$\begin{array}{l}\Xi \\
\vdots \\
\vdots \\
\vdots \\
\vdots\end{array}$} & Leaves: & 48,108 & \multirow{4}{*}{$\begin{array}{l}\text { Leaves: } \\
\text { Grass: }\end{array}$} & \multirow{4}{*}{$\begin{array}{l}54,803 \\
(74.4 \%) \\
18,898 \\
(25.6 \%)\end{array}$} & \multirow{4}{*}{73,701} \\
\hline & $\begin{array}{l}\text { Stadtreinigung } \\
(B S R)\end{array}$ & Grass: & 4,758 & & & & & Grass: & 4,758 & & & \\
\hline & \multirow{2}{*}{\begin{tabular}{|l} 
Parks \\
departments \\
\end{tabular}} & Leaves: & 13,134 & & & & & Leaves: & 6,695 & & & \\
\hline & & Grass: & 27,738 & & & & & Grass: & 14,140 & & & \\
\hline & Private & Leaves: & 11,009 & & & & \multirow{5}{*}{ 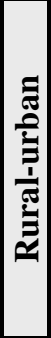 } & Leaves: & 9,829 & Leaves: & $\mathbf{9 , 8 2 9}$ & \multirow{5}{*}{75,621} \\
\hline & $\begin{array}{l}\text { gardening \& } \\
\text { landscaping } \\
\text { firms }\end{array}$ & Grass: & 15,862 & & $\begin{array}{l}\text { Leaves: } \\
\text { Grass: }\end{array}$ & $\begin{array}{l}11,009 \\
15,862\end{array}$ & & Grass: & 14,162 & Grass: & $\begin{array}{l}(13.0 \%) \\
14,162 \\
(18.7 \%)\end{array}$ & \\
\hline \multirow{5}{*}{ 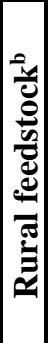 } & Havelland & Grass: & 33,529 & \multirow{5}{*}{143,381} & \multirow{3}{*}{ Grass: } & \multirow{3}{*}{57,825} & & Grass: & 29,936 & \multirow{3}{*}{ Grass: } & \multirow{3}{*}{$\begin{array}{l}51,629 \\
(68.3 \%)\end{array}$} & \\
\hline & $\begin{array}{l}\text { Brandenburg/ } \\
\text { Havel }\end{array}$ & Grass: & 10,608 & & & & & Grass: & 9,471 & & & \\
\hline & Potsdam & Grass: & 13,689 & & & & & Grass: & 12,222 & & & \\
\hline & $\begin{array}{l}\text { Potsdam- } \\
\text { Mittelmark }\end{array}$ & Grass: & 45,346 & & \multirow{2}{*}{ Grass: } & \multirow{2}{*}{85,556} & \multirow{2}{*}{ 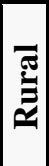 } & Grass: & 43,123 & \multirow{2}{*}{ Grass: } & \multirow{2}{*}{$\begin{array}{r}81,361 \\
(100 \%)\end{array}$} & \multirow{2}{*}{81,361} \\
\hline & \begin{tabular}{|l} 
Teltow- \\
Fläming
\end{tabular} & Grass: & 40,210 & & & & & Grass: & 38,238 & & & \\
\hline
\end{tabular}

Sources:

a) Vogt et al. (2012: 121, 123, and 125) and ICU (2011: Table 7). The 48,108 Mg FM/a leaves collected by BSR are split into $32,253 \mathrm{Mg} \mathrm{FM} / \mathrm{a}$ loose leaves from roads and 15,855 Mg FM/a yard leaves collected through leaf sacks (Vogt et al. 2012: 121 and 123).

b) Derived from the theoretical green-waste potentials provided by Zentner (2012), assuming that the technical biomass potentials are half of the corresponding theoretical potentials and that grass cuttings account for $75 \%$ of all collected green waste.

c) Own assumptions.

d) Own assumptions, targeting the HTC capacity of 55,000 $\mathrm{Mg} \mathrm{FM}_{\text {prep }} / \mathrm{a}$ in each scenario and using the share of prepared biomass of $67.6 \%$ (95.0\%) for rural grass cuttings and urban leaves (urban grass cuttings) as given in Table 2. For the urban scenario, it is assumed that BSR uses all of its biomass potentials for HTC, while the biomass potentials collected by the parks departments are downward-adjusted proportionally to their shares in prepared FM (obtained when only considering the biomass potentials of the parks departments). In the ruralurban and rural scenarios, all the biomass potentials are downward-adjusted proportionally to their respective shares in prepared FM. Note that the percentage shares in the second-last column refer to each feedstock's share in the respective total FM input of the scenario (last column).

Note: Values rounded. 
Table 2: Life-Cycle Mass Balances

\begin{tabular}{|c|c|c|c|c|c|c|}
\hline & & \multicolumn{3}{|c|}{$\overline{\text { HTC }}$} & \multicolumn{2}{|c|}{ Composting $^{\mathrm{c}}$} \\
\hline & & $\begin{array}{c}\text { Rural grass } \\
\text { cuttings and } \\
\text { urban leaves }^{\mathrm{a}}\end{array}$ & \multicolumn{2}{|c|}{$\begin{array}{c}\text { Urban grass } \\
\text { cuttings }^{b}\end{array}$} & Leaves & $\begin{array}{c}\text { Grass } \\
\text { cuttings }\end{array}$ \\
\hline & & $\%$ & \multicolumn{2}{|c|}{$\%$} & $\%$ & $\%$ \\
\hline \multirow{6}{*}{$\begin{array}{l}\text { FM biomass } \\
\text { input }\end{array}$} & DM content & 46.0 & & 25.0 & - & - \\
\hline & Organic dry substance & 30.0 & & 21.2 & - & - \\
\hline & Water content & 54.0 & & 75.0 & - & - \\
\hline & Inert material & 16.0 & & 3.8 & - & - \\
\hline & "Residues after preparation & 32.4 & & 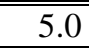 & 8.0 & 8.0 \\
\hline & Prepared biomass & 67.6 & & 95.0 & 92.0 & 92.0 \\
\hline \multirow{5}{*}{$\begin{array}{l}\text { Outputs } \\
\text { from } \\
\text { conversion } \\
\text { process }^{*}\end{array}$} & Gases & 2.8 & 0.4 & - & 43.0 & 65.0 \\
\hline & Wastewater & 40.4 & 73.4 & - & - & - \\
\hline & HTC coal & 24.4 & 21.2 & $17.3^{\mathrm{d}}$ & - & - \\
\hline & Compost & - & & - & 40.0 & 18.0 \\
\hline & Screening losses & - & & - & 9.0 & 9.0 \\
\hline \multirow[t]{3}{*}{ HTC coal } & Organic dry substance & 83.0 & 69.3 & - & - & - \\
\hline & Water content & 8.0 & 25.0 & $8.0^{\mathrm{a}}$ & - & - \\
\hline & Ash content & 9.0 & 5.7 & - & - & - \\
\hline
\end{tabular}

Sources:

a) SunCoal (2012: 3-4), referring to green waste.

b) ICU (unpublished data).

c) Kranert and Cord-Landwehr (2010: 228).

d) Own calculation, relating the output share of HTC coal to the different HTC-coal water content.

Notes:

* The share of outputs obtained from the conversion process is related to the total FM biomass input. The respective output shares add up to the share of prepared biomass in the FM biomass input since only prepared biomass enters the conversion process.

- Not available/applicable. 
Table 3: Life-Cycle Energy Balances

\begin{tabular}{|c|c|c|c|c|c|c|c|}
\hline & \multicolumn{3}{|c|}{ HTC } & \multicolumn{3}{|c|}{ Composting } \\
\hline & & Urban & $\begin{array}{l}\text { Rural- } \\
\text { urban }\end{array}$ & Rural & Urban & $\begin{array}{c}\text { Rural- } \\
\text { urban }\end{array}$ & Rural \\
\hline \multicolumn{8}{|c|}{ Energy input (kWh/Mg FM input) } \\
\hline Input material & LHV of initial FM biomass $^{\mathrm{a}}$ & $1,289.2$ & $1,316.1$ & $1,388.9$ & - & - & \\
\hline Transportation & Diesel fuel ${ }^{\mathrm{b}}$ & 40.2 & 19.9 & 25.1 & 24.8 & 14.7 & 18.5 \\
\hline \multirow{2}{*}{$\begin{array}{l}\text { Baling and } \\
\text { storage }\end{array}$} & Electricity for baling press ${ }^{\mathrm{c}}$ & 3.0 & 3.0 & 3.0 & - & - & - \\
\hline & Diesel for feeding $^{\mathrm{c}}$ & 5.0 & 5.0 & 5.0 & - & - & - \\
\hline \multirow{6}{*}{$\begin{array}{l}\text { Auxiliary } \\
\text { energy } \\
\text { requirements }\end{array}$} & Electricity for biomass prep. ${ }^{\mathrm{d}}$ & 5.0 & 5.0 & 5.0 & - & - & - \\
\hline & Diesel for biomass feeding ${ }^{\mathrm{e}}$ & 3.0 & 3.0 & 3.0 & - & - & - \\
\hline & Natural gas for reactor heating ${ }^{f}$ & 34.2 & 33.3 & 31.0 & - & - & - \\
\hline & \begin{tabular}{|l|} 
Electricity for HTC-coal drying \\
g
\end{tabular} & 58.0 & 56.5 & 52.5 & - & - & - \\
\hline & $\begin{array}{l}\text { Diesel for composting (including } \\
\text { biomass preparation and feeding) }\end{array}$ & - & - & - & 24.9 & 24.9 & 24.9 \\
\hline & $\begin{array}{l}\text { Electricity for equipment and } \\
\text { buildings } \mathrm{h}\end{array}$ & & - & & 0.5 & 0.5 & 0.5 \\
\hline \multicolumn{2}{|c|}{ Total energy input (kWh/Mg FM input) } & $1,437.5$ & $\mathbf{1 , 4 4 1 . 8}$ & $\mathbf{1 , 5 1 3 . 5}$ & 50.2 & 40.0 & 43.8 \\
\hline \multicolumn{8}{|c|}{ Energy output (kWh/Mg FM input) } \\
\hline & Energy content of HTC coal ${ }^{\mathrm{i}}$ & $1,254.4$ & $1,281.7$ & $1,355.6$ & 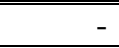 & - & 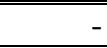 \\
\hline- & Conversion losses (combustion) $^{\mathrm{j}}$ & 100.4 & 358.9 & 379.6 & - & - & - \\
\hline$=$ & Usable energy from HTC coal & $\mathbf{1 , 1 5 4 . 1}$ & 922.8 & 976.0 & - & - & 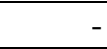 \\
\hline \multirow[t]{2}{*}{ Thereof: } & Usable heat ${ }^{\mathrm{k}}$ & 878.1 & 499.9 & 528.7 & - & - & - \\
\hline & Usable electricity $^{1}$ & 276.0 & 423.0 & 447.3 & - & - & \\
\hline \multicolumn{2}{|c|}{$\begin{array}{l}\text { Overall energy balance (kWh/Mg FM input) } \\
\text { (usable energy from HTC coal - total energy input) }\end{array}$} & -283.4 & -519.0 & -537.5 & - & - & \\
\hline
\end{tabular}

Sources:

a) Own calculation, based on the feedstock shares in Table 1 and the LHVs of approximately 5.0 MJ/kg FM $(1,388.9 \mathrm{kWh} / \mathrm{Mg} \mathrm{FM})$ for rural grass cuttings and urban leaves (cf. Zentner 2013: 8; Vogt et al. 2012: 121) and $3.6 \mathrm{MJ} / \mathrm{kg} \mathrm{FM}(1,000.0 \mathrm{kWh} / \mathrm{Mg} \mathrm{FM})$ for urban grass cuttings. The LHV for urban grass cuttings is deducted from the LHV of HTC coal, at a $92 \%$ DM content, of $20 \mathrm{MJ} / \mathrm{kg}$ HTC coal (SunCoal 2012: 2) and the corresponding HTC-coal yield of $17.3 \%$ (Table 2).

b) Own calculation, based on 0.4 liter diesel/ $\mathrm{km}$ (Table 4), $9.94 \mathrm{kWh} /$ liter diesel (Table 4), the respective biomass totals given in the last column of Table 1, and the total $\mathrm{km}$ in the last line of Tables 5 to 10 , respectively.

c) Vogt et al. (2012: 221).

d) ICU (unpublished data).

e) Own calculation, based on 0.3 liter diesel per Mg FM input (Vogt et al. 2012: XXVI) and $9.94 \mathrm{kWh} /$ liter diesel (Table 4).

f) Own calculation, based on an HTC plant's capacity to consume $330 \mathrm{~kW} / \mathrm{a}$ of natural gas (SunCoal 2012: 3), combined with 7,632 annual operating hours (SunCoal 2012: 2) and the annual biomass inputs from Table 1.

g) Own calculation, based on an HTC plant's capacity to consume $560 \mathrm{~kW} / \mathrm{a}$ of electricity (SunCoal 2012: 3), combined with 7,632 annual operating hours (SunCoal 2012:2) and the annual biomass inputs from Table 1.

h) Vogt et al. (2012: 116). The diesel-fuel consumption for composting is based on 2.5 liters diesel per Mg FM input (Vogt et al. 2012: 116). As in Table 4, we assume $9.94 \mathrm{kWh} /$ liter diesel.

i) Own calculation, based on the LHV of HTC coal, at a $92 \%$ DM content, of $20 \mathrm{MJ} / \mathrm{kg}$ (SunCoal 2012: 2) (equivalent to about 5,555.6 kWh/Mg HTC coal), the annual amounts of HTC coal given in Section 3.1.1, and the annual biomass inputs from Table 1.

j) Own calculation, based on total CHP-plant efficiencies of 92\% (Obernberger and Thek 2004: 6) in the urban HTC scenario and 72\% (Vogt et al. 2012: III) in the rural-urban and rural HTC scenarios.

k) Own calculation, based on thermal CHP-plant efficiencies of 70\% (Obernberger and Thek 2004: 6) in the urban HTC scenario and 39\% (Vogt et al. 2012: III) in the rural-urban and rural HTC scenarios.

1) Own calculation, based on electrical CHP-plant efficiencies of 22\% (Obernberger and Thek 2004: 6) in the urban HTC scenario and 33\% (Vogt et al. 2012: III) in the rural-urban and rural HTC scenarios.

Notes: Values rounded. - Not applicable. 
Table 4: Transportation Data for Semi-Trailer Trucks

\begin{tabular}{|c|c|c|c|c|c|}
\hline & Unit & Leaves & $\begin{array}{c}\text { Grass } \\
\text { cuttings }\end{array}$ & $\begin{array}{c}\text { HTC coal } \\
\text { (dust) }\end{array}$ & Compost \\
\hline \multirow{2}{*}{ Load capacity ${ }^{a}$} & $\mathrm{~m}^{3} /$ tour & \multicolumn{4}{|c|}{40} \\
\hline & $\mathrm{Mg} /$ tour & \multicolumn{4}{|c|}{20} \\
\hline $\begin{array}{l}\text { Bulk density } \\
\text { (biomass: before baling) }\end{array}$ & \multirow{2}{*}{$\mathrm{kg} / \mathrm{m}^{3}$} & 250 & 350 & \multirow{2}{*}{450} & \multirow{2}{*}{500} \\
\hline $\begin{array}{l}\text { Bulk density } \\
\text { (biomass: after baling) }\end{array}$ & & 650 & 500 & & \\
\hline $\begin{array}{l}\text { Load }^{\mathrm{c}} \\
\text { (biomass: before baling) }\end{array}$ & \multirow{2}{*}{$\mathrm{Mg} /$ tour } & 10 & 14 & \multirow{2}{*}{18} & \multirow{2}{*}{20} \\
\hline $\begin{array}{l}\text { Load }^{\mathrm{c}} \\
\text { (biomass: after baling) }\end{array}$ & & 20 & 20 & & \\
\hline Diesel consumption $^{\mathrm{a}}$ & liter $/ \mathrm{km}$ & \multicolumn{4}{|c|}{0.4} \\
\hline Energy consumption $^{\mathrm{d}}$ & $\mathrm{kWh} /$ liter diesel & \multicolumn{4}{|c|}{9.94} \\
\hline
\end{tabular}

Sources:

a) Zentner (2013: 12).

b) ICU (2011: 6); Vogt et al. (2012: 219); Zentner (2013: 12); Brunstermann (2007).

c) Own calculation.

d) SenGUV and BSR (2011).

Table 5: Transport Distances and Costs in the Urban HTC Scenario

\begin{tabular}{|c|c|c|c|c|c|c|c|}
\hline \multicolumn{8}{|c|}{$\begin{array}{l}\text { Transports of leaf sacks from } 13 B S R \text { recycling points to the three } B S R \text { recycling points in Lichtenberg, } \\
\text { Steglitz, and Spandau (Note: Leaf sacks collected at the latter } B S R \text { recycling points are not transported at this stage.) }\end{array}$} \\
\hline \multirow[t]{2}{*}{$\begin{array}{l}\text { BSR recycling points } \\
\text { (RPs) }\end{array}$} & $d_{r}^{\mathrm{a}}$ & $C_{\text {tour }, r^{\mathbf{b}}}$ & $\begin{array}{c}\text { Biomass } \\
\text { potentials }^{c}\end{array}$ & $\begin{array}{c}\text { Biomass } \\
\text { scenario } \\
\text { allocation }^{\mathrm{d}}\end{array}$ & tour $_{r}^{\mathrm{e}}$ & $C_{\text {trans }, r} \mathbf{f}$ & Total km ${ }^{\mathrm{g}}$ \\
\hline & $\mathrm{km}$ & $€ /$ tour & $\mathrm{Mg} \mathrm{FM} / \mathrm{a}$ & $\mathrm{Mg} \mathrm{FM} / \mathrm{a}$ & \# & $€ / \mathrm{a}$ & $\mathrm{km}$ \\
\hline \multicolumn{8}{|c|}{ Transports to the $B S R$ recycling point in Lichtenberg (Fischerstraße) } \\
\hline RP Asgardstraße & 10.8 & 139 & 991 & 991 & 99 & 13,727 & 2,140 \\
\hline RP Behmstraße & 11.6 & 141 & 991 & 991 & 99 & 13,954 & 2,299 \\
\hline RP Nordring & 11.3 & 140 & 991 & 991 & 99 & 13,869 & 2,240 \\
\hline RP Rahnsdorfer Straße & 11.4 & 140 & 991 & 991 & 99 & 13,897 & 2,259 \\
\hline RP Oberspreestraße & 9.6 & 135 & 991 & 991 & 99 & 13,386 & 1,903 \\
\hline \multicolumn{8}{|c|}{ Transports to the $B S R$ recycling point in Steglitz (Ostpreußendamm) } \\
\hline RP Gradestraße & 8.4 & 132 & 991 & 991 & 99 & 13,045 & 1,665 \\
\hline RP Hegauer Weg & 8.9 & 133 & 991 & 991 & 99 & 13,187 & 1,764 \\
\hline RP Berliner Straße & 5.0 & 122 & 991 & 991 & 99 & 12,079 & 991 \\
\hline RP Tempelhofer Weg & 8.0 & 130 & 991 & 991 & 99 & 12,931 & 1,586 \\
\hline \multicolumn{8}{|c|}{ Transports to the BSR recycling point in Spandau (Ruhleben) } \\
\hline RP Brunsbüt. Damm & 4.3 & 120 & 991 & 991 & 99 & 11,880 & 852 \\
\hline RP Ruppiner Chaussee & 17.7 & 158 & 991 & 991 & 99 & 15,688 & 3,508 \\
\hline RP Ilsenburger Straße & 6.4 & 126 & 991 & 991 & 99 & 12,476 & 1,268 \\
\hline RP Lengeder Straße & 13.3 & 146 & 991 & 991 & 99 & 14,437 & 2,636 \\
\hline Total & - & - & 12,882 & 12,882 & - & 174,556 & 25,110 \\
\hline
\end{tabular}

Table continues on next page. 


\section{Table 5 continued}

\begin{tabular}{|c|c|c|c|c|c|c|c|}
\hline \multicolumn{8}{|c|}{$\begin{array}{l}\text { Transports of leaf sacks (unprepared) from the three } B S R \text { recycling points in Lichtenberg, Steglitz, and } \\
\text { Spandau to the preparation-and-storage site in Hennickendorf }\end{array}$} \\
\hline \multirow[t]{2}{*}{$B S R$ recycling points } & $d_{r}^{\mathrm{a}}$ & $C_{\text {tour }, r^{\mathbf{b}}}$ & $\begin{array}{c}\text { Biomass } \\
\text { potentials }^{h}\end{array}$ & $\begin{array}{c}\text { Biomass } \\
\text { scenario } \\
\text { allocation }^{\mathrm{d}}\end{array}$ & tour $_{r}^{\mathrm{e}}$ & $C_{\text {trans, } r}{ }^{\mathbf{r}}$ & Total km ${ }^{\mathrm{g}}$ \\
\hline & $\mathrm{km}$ & $€ /$ tour & $\mathrm{Mg}$ FM/a & $\mathrm{Mg}$ FM/a & $\#$ & $€ / \mathrm{a}$ & $\mathrm{km}$ \\
\hline Lichtenberg & 25.9 & 182 & 5,946 & 5,946 & 595 & 108,110 & 30,798 \\
\hline Steglitz & 40.6 & 224 & 4,955 & 4,955 & 495 & 110,980 & 40,232 \\
\hline Spandau & 43.6 & 233 & 4,955 & 4,955 & 495 & 115,243 & 43,205 \\
\hline Total & - & - & 15,855 & 15,855 & - & 334,334 & 114,235 \\
\hline \multicolumn{8}{|c|}{$\begin{array}{l}\text { Transports of loose leaves (unprepared) from the three } B S R \text { recycling points in Lichtenberg, Steglitz, } \\
\text { and Spandau to the preparation-and-storage site in Hennickendorf }\end{array}$} \\
\hline \multirow[t]{2}{*}{$B S R$ recycling points } & $d_{r}^{\mathrm{a}}$ & $C_{\text {tour }, r^{b}}$ & $\begin{array}{c}\text { Biomass } \\
\text { potentials }\end{array}$ & $\begin{array}{c}\text { Biomass } \\
\text { scenario } \\
\text { allocation }^{\mathrm{d}}\end{array}$ & tour $_{r}^{\mathrm{e}}$ & $C_{\text {trans }, r} \mathbf{f}$ & Total km km $^{\mathrm{g}}$ \\
\hline & $\mathrm{km}$ & $€ /$ tour & $\mathrm{Mg} \mathrm{FM} / \mathrm{a}$ & $\mathrm{Mg} \mathrm{FM} / \mathrm{a}$ & $\#$ & $€ / \mathrm{a}$ & $\mathrm{km}$ \\
\hline Lichtenberg & 25.9 & 182 & 10,751 & 10,751 & 1,075 & 195,487 & 55,690 \\
\hline Steglitz & 40.6 & 224 & 10,751 & 10,751 & 1,075 & 240,813 & 87,298 \\
\hline Spandau & 43.6 & 233 & 10,751 & 10,751 & 1,075 & 250,063 & 93,749 \\
\hline Total & - & - & 32,253 & 32,253 & - & 686,362 & 236,737 \\
\hline \multicolumn{8}{|c|}{$\begin{array}{l}\text { Transports of grass cuttings (unprepared) from the three BSR recycling points in Lichtenberg, Steglitz, } \\
\text { and Spandau to the preparation-and-storage site in Hennickendorf }\end{array}$} \\
\hline \multirow[t]{2}{*}{$B S R$ recycling points } & $d_{r}^{\mathrm{a}}$ & $C_{\text {tour }, r} \mathbf{b}$ & $\begin{array}{c}\text { Biomass } \\
\text { potentials }^{j}\end{array}$ & $\begin{array}{c}\text { Biomass } \\
\text { scenario } \\
\text { allocation }^{\text {d }}\end{array}$ & tour $_{r}^{\mathrm{k}}$ & $C_{\text {trans, } r} \mathbf{f}$ & Total km ${ }^{\mathrm{g}}$ \\
\hline & $\mathrm{km}$ & $€ /$ tour & $\mathrm{Mg}$ FM/a & $\mathrm{Mg}$ FM/a & $\#$ & $€ / \mathrm{a}$ & $\mathrm{km}$ \\
\hline Lichtenberg & 25.9 & 182 & 1,586 & 1,586 & 113 & 20,599 & 5,868 \\
\hline Steglitz & 40.6 & 224 & 1,586 & 1,586 & 113 & 25,375 & 9,199 \\
\hline Spandau & 43.6 & 233 & 1,586 & 1,586 & 113 & 26,350 & 9,879 \\
\hline Total & - & - & 4,758 & 4,758 & - & 72,324 & 24,946 \\
\hline \multicolumn{8}{|c|}{$\begin{array}{l}\text { Transports of leaves (unprepared) from the parks departments to the preparation-and-storage site in } \\
\text { Hennickendorf }\end{array}$} \\
\hline \multirow[t]{2}{*}{ Parks departments } & $d_{r}{ }^{\mathrm{a}}$ & $C_{\text {tour }, r} \mathbf{b}$ & $\begin{array}{c}\text { Biomass } \\
\text { potentials }^{1}\end{array}$ & $\begin{array}{l}\text { Biomass } \\
\text { scenario } \\
\text { alloc. }^{m} \\
\end{array}$ & tour $_{r}^{\mathrm{e}}$ & $C_{\text {trans, }, r}$ & Total km ${ }^{\mathrm{g}}$ \\
\hline & $\mathrm{km}$ & $€ /$ tour & $\mathrm{Mg} \mathrm{FM} / \mathrm{a}$ & $\mathrm{Mg}$ FM/a & $\#$ & $€ / \mathrm{a}$ & $\mathrm{km}$ \\
\hline Charl.-Wilmersdorf & 28.1 & 188 & 1,430 & 729 & 73 & 13,715 & 4,097 \\
\hline Friedr.-Kreuzberg & 27.0 & 185 & 723 & 369 & 37 & 6,818 & 1,990 \\
\hline Lichtenberg & 26.8 & 184 & 975 & 497 & 50 & 9,166 & 2,664 \\
\hline Marzahn-Hellersdorf & 19.8 & 164 & 1,250 & 637 & 64 & 10,472 & 2,523 \\
\hline Mitte & 36.1 & 211 & 871 & 444 & 44 & 9,372 & 3,206 \\
\hline Neukölln & 30.6 & 195 & 625 & 319 & 32 & 6,223 & 1,950 \\
\hline Pankow & 34.7 & 207 & 1,371 & 699 & 70 & 14,472 & 4,850 \\
\hline Reinickendorf & 27.1 & 185 & 1,430 & 729 & 73 & 13,506 & 3,951 \\
\hline Spandau & 35.2 & 209 & 855 & 436 & 44 & 9,088 & 3,068 \\
\hline Steglitz-Zehlendorf & 45.4 & 238 & 1,750 & 892 & 89 & 21,210 & 8,100 \\
\hline Tempelhof-Schöneberg & 37.0 & 214 & 750 & 382 & 38 & 8,169 & 2,829 \\
\hline Treptow-Köpenick & 21.7 & 170 & 1,104 & 563 & 56 & 9,555 & 2,442 \\
\hline$\overline{\text { Total }}$ & - & - & 13,134 & 6,695 & - & 131,764 & 41,671 \\
\hline
\end{tabular}

Table continues on next page. 


\section{Table 5 continued}

\begin{tabular}{|c|c|c|c|c|c|c|c|}
\hline \multicolumn{8}{|c|}{$\begin{array}{l}\text { Transports of grass cuttings (unprepared) from the parks departments to the preparation-and-storage } \\
\text { site in Hennickendorf }\end{array}$} \\
\hline \multirow[t]{2}{*}{ Parks departments } & $d_{r}^{\mathrm{a}}$ & $C_{\text {tour }, r^{b}}$ & $\begin{array}{c}\text { Biomass } \\
\text { potentials }\end{array}$ & $\begin{array}{l}\text { Biomass } \\
\text { scenario } \\
\text { alloc. }^{m}\end{array}$ & tour $_{r}^{\mathrm{k}}$ & $C_{\text {trans, }}{ }^{\mathbf{f}}$ & Total km kg $^{\mathrm{g}}$ \\
\hline & $\mathrm{km}$ & $€ /$ tour & $\mathrm{Mg} \mathrm{FM/a}$ & $\mathrm{Mg} \mathrm{FM} / \mathrm{a}$ & $\#$ & $€ / \mathrm{a}$ & $\mathrm{km}$ \\
\hline Charl.-Wilmersdorf & 28.1 & 188 & 1,312 & 669 & 48 & 8,988 & 2,685 \\
\hline Friedr.-Kreuzberg & 27.0 & 185 & 794 & 405 & 29 & 5,348 & 1,561 \\
\hline Lichtenberg & 26.8 & 184 & 2,647 & 1,349 & 96 & 17,774 & 5,166 \\
\hline Marzahn-Hellersdorf & 19.8 & 164 & 3,264 & 1,664 & 119 & 19,531 & 4,706 \\
\hline Mitte & 36.1 & 211 & 2,512 & 1,281 & 91 & 19,307 & 6,604 \\
\hline Neukölln & 30.6 & 195 & 1,606 & 819 & 58 & 11,421 & 3,579 \\
\hline Pankow & 34.7 & 207 & 3,260 & 1,662 & 119 & 24,580 & 8,238 \\
\hline Reinickendorf & 27.1 & 185 & 2,510 & 1,280 & 91 & 16,933 & 4,954 \\
\hline Spandau & 35.2 & 209 & 2,980 & 1,519 & 109 & 22,624 & 7,639 \\
\hline Steglitz-Zehlendorf & 45.4 & 238 & 2,706 & 1,379 & 99 & 23,426 & 8,947 \\
\hline Tempelhof-Schöneberg & 37.0 & 214 & 1,132 & 577 & 41 & 8,807 & 3,050 \\
\hline Treptow-Köpenick & 21.7 & 170 & 3,015 & 1,537 & 110 & 18,639 & 4,765 \\
\hline Total & - & - & 27,738 & 14,140 & - & 197,379 & 61,893 \\
\hline \multicolumn{8}{|c|}{$\begin{array}{l}\text { Transports of prepared urban biomass from the preparation-and-storage site in Hennickendorf to the } \\
\text { HTC plant in Spandau (Ruhleben) }\end{array}$} \\
\hline \multirow[t]{2}{*}{ Urban biomass } & $d_{r}^{\mathrm{a}}$ & $C_{\text {tour }, r^{\mathbf{b}}}$ & \multicolumn{2}{|c|}{ Prepared biomass $^{n}$} & tour $_{r}^{0}$ & $C_{\text {trans }, r} \mathbf{f}$ & Total km ${ }^{\mathrm{g}}$ \\
\hline & $\mathrm{km}$ & $€ /$ tour & \multicolumn{2}{|c|}{$\mathrm{Mg} \mathrm{FM}_{\text {prep }} / \mathrm{a}$} & $\#$ & $€ / \mathrm{a}$ & $\mathrm{km}$ \\
\hline Leaves & 43.6 & 233 & & 37,047 & 1,852 & 430,847 & 161,525 \\
\hline Grass cuttings & 43.6 & 233 & & 17,953 & 898 & 208,789 & 78,275 \\
\hline Total & - & - & & 55,000 & - & 639,636 & 239,800 \\
\hline & & & & & & $\sum_{r} \boldsymbol{C}_{\text {trans }, r}$ & Total km \\
\hline & & & & & & $€ / \mathrm{a}$ & $\mathrm{km}$ \\
\hline & & & & Total tran & sports: & $2,236,355$ & 744,392 \\
\hline
\end{tabular}

Sources:

a) Own calculation, based on Google Maps.

b) Own calculation, based on equation (10).

c) Own assumption, distributing the total potential of yard leaves collected through leaf sacks (15,855 Mg FM/a, Vogt et al. 2012: 121) evenly across the 16 BSR recycling points. Note that the leaf sacks collected at the recycling points in Lichtenberg, Steglitz, and Spandau are directly transported to the preparation-and-storage site in Hennickendorf, forgoing the first transport stage.

d) Own assumption, allocating the entire $B S R$ biomass potentials to the urban HTC scenario.

e) Own calculation, dividing the allocated biomass by the biomass load (before baling) of $10 \mathrm{Mg} / \mathrm{tour}$ (Table 4 ).

f) Own calculation, based on equation (9)

g) Own calculation, multiplying $2 d_{r}$ by tour $_{r}$.

h) Sum of leaves from leaf sacks transported to each recycling point plus the leaves from leaf sacks directly collected at the respective recycling point.

i) Own assumption, distributing the total potential of loose leaves from roads collected by $B S R$ (32,253 Mg FM/a, Vogt et al. 2012: 123) evenly across the three BSR recycling points in Lichtenberg, Steglitz, and Spandau.

j) Own assumption, distributing the total potential of grass cuttings collected by $B S R$ (4,758 Mg FM/a, Vogt et al. 2012: 125) evenly across the three BSR recycling points in Lichtenberg, Steglitz, and Spandau.

k) Own calculation, dividing the allocated biomass by the biomass load (before baling) of $14 \mathrm{Mg} / \mathrm{tour}$ (Table 4 ).

1) ICU (2011: Table 7).

m) Own calculation, downward-adjusting the potentials of leaves (grass cuttings) accruing at the single parks departments proportionally to the downward-adjustment of the total potential of leaves (grass cuttings) of the parks departments (see Table 1).

n) Own calculation, multiplying the total allocated urban leaves $(54,803 \mathrm{Mg}$ FM/a, Table 1) and grass cuttings (18,898 Mg FM/a, Table 1) by their respective share of prepared biomass (67.6\% for urban leaves and $95.0 \%$ for urban grass cuttings, Table 2).

o) Own calculation, dividing the prepared biomass by the biomass load (after baling) of $20 \mathrm{Mg} / \mathrm{tour}$ (Table 4 ).

Notes: Values rounded. - Not applicable. 
Table 6: Transport Distances and Costs in the Rural-Urban HTC Scenario

\begin{tabular}{|c|c|c|c|c|c|c|c|}
\hline \multicolumn{8}{|c|}{$\begin{array}{l}\text { Transports of urban leaves (unprepared) from the private gardening and landscaping firms in Berlin to } \\
\text { the preparation-and-storage site in Ahrensfelde }\end{array}$} \\
\hline \multirow[t]{2}{*}{$\begin{array}{l}\text { Private gardening \& } \\
\text { landscaping firms }\end{array}$} & $d_{r}{ }^{\mathrm{a}}$ & $C_{\text {tour }, r^{\mathbf{b}}}$ & $\begin{array}{c}\text { Biomass } \\
\text { potentials }\end{array}$ & $\begin{array}{l}\text { Biomass } \\
\text { scenario } \\
\text { allocation }^{\text {d }}\end{array}$ & tour $_{r}^{\mathrm{e}}$ & $C_{\text {trans }, r} \mathbf{f}$ & Total km k $^{\mathrm{g}}$ \\
\hline & $\mathrm{km}$ & $€ /$ tour & $\mathrm{Mg}$ FM/a & $\mathrm{Mg}$ FM/a & $\#$ & $€ / \mathrm{a}$ & $\mathrm{km}$ \\
\hline Charl.-Wilmersdorf & 28.1 & 188 & 917 & 819 & 82 & 15,411 & 4,603 \\
\hline Friedr.-Kreuzberg & 18.5 & 161 & 917 & 819 & 82 & 13,156 & 3,031 \\
\hline Lichtenberg & 16.5 & 155 & 917 & 819 & 82 & 12,686 & 2,703 \\
\hline Marzahn-Hellersdorf & 7.9 & 130 & 917 & 819 & 82 & 10,665 & 1,294 \\
\hline Mitte & 25.7 & 181 & 917 & 819 & 82 & 14,847 & 4,210 \\
\hline Neukölln & 22.8 & 173 & 917 & 819 & 82 & 14,166 & 3,735 \\
\hline Pankow & 20.7 & 167 & 917 & 819 & 82 & 13,672 & 3,391 \\
\hline Reinickendorf & 27.1 & 185 & 917 & 819 & 82 & 15,176 & 4,440 \\
\hline Spandau & 35.2 & 209 & 917 & 819 & 82 & 17,079 & 5,767 \\
\hline Steglitz-Zehlendorf & 36.0 & 211 & 917 & 819 & 82 & 17,267 & 5,898 \\
\hline Tempelhof-Schöneberg & 27.7 & 187 & 917 & 819 & 82 & 15,317 & 4,538 \\
\hline Treptow-Köpenick & 17.2 & 157 & 917 & 819 & 82 & 12,850 & 2,818 \\
\hline Total & - & - & $\overline{11,009}$ & $\overline{9,829}$ & - & 172,291 & $\overline{46,427}$ \\
\hline \multicolumn{8}{|c|}{$\begin{array}{l}\text { Transports of urban grass cuttings (unprepared) from the private gardening and landscaping firms in } \\
\text { Berlin to the preparation-and-storage site in Ahrensfelde }\end{array}$} \\
\hline \multirow[t]{2}{*}{$\begin{array}{l}\text { Private gardening \& } \\
\text { landscaping firms }\end{array}$} & $d_{r}{ }^{\mathrm{a}}$ & $C_{t o u r, r}^{b}$ & $\begin{array}{c}\text { Biomass } \\
\text { potentials }\end{array}$ & $\begin{array}{l}\text { Biomass } \\
\text { scenario } \\
\text { allocation }^{\text {d }}\end{array}$ & tour $_{r}^{\mathrm{h}}$ & $C_{\text {trans }, r}{ }^{\mathbf{f}}$ & Total km km $^{\mathrm{g}}$ \\
\hline & $\mathrm{km}$ & $€ /$ tour & $\mathrm{Mg} \mathrm{FM} / \mathrm{a}$ & $\mathrm{Mg} \mathrm{FM} / \mathrm{a}$ & $\#$ & $€ / \mathrm{a}$ & $\mathrm{km}$ \\
\hline Charl.-Wilmersdorf & 28.1 & 188 & 1,322 & 1,180 & 84 & 15,860 & 4,738 \\
\hline Friedr.-Kreuzberg & 18.5 & 161 & 1,322 & 1,180 & 84 & 13,539 & 3,119 \\
\hline Lichtenberg & 16.5 & 155 & 1,322 & 1,180 & 84 & 13,056 & 2,782 \\
\hline Marzahn-Hellersdorf & 7.9 & 130 & 1,322 & 1,180 & 84 & 10,976 & 1,332 \\
\hline Mitte & 25.7 & 181 & 1,322 & 1,180 & 84 & 15,280 & 4,333 \\
\hline Neukölln & 22.8 & 173 & 1,322 & 1,180 & 84 & 14,579 & 3,844 \\
\hline Pankow & 20.7 & 167 & 1,322 & 1,180 & 84 & 14,071 & 3,490 \\
\hline Reinickendorf & 27.1 & 185 & 1,322 & 1,180 & 84 & 15,618 & 4,569 \\
\hline Spandau & 35.2 & 209 & 1,322 & 1,180 & 84 & 17,577 & 5,935 \\
\hline Steglitz-Zehlendorf & 36.0 & 211 & 1,322 & 1,180 & 84 & 17,770 & 6,070 \\
\hline Tempelhof-Schöneberg & 27.7 & 187 & 1,322 & 1,180 & 84 & 15,763 & 4,670 \\
\hline Treptow-Köpenick & 17.2 & 157 & 1,322 & 1,180 & 84 & 13,225 & 2,900 \\
\hline Total & - & - & $\overline{15,862}$ & $\overline{14,162}$ & - & 177,315 & $\overline{47,781}$ \\
\hline \multicolumn{8}{|c|}{$\begin{array}{l}\text { Transports of rural grass cuttings (unprepared) from the municipal green-waste collection points in } \\
\text { Havelland to the preparation-and-storage site in Nauen (Note: No transports occur for rural grass cuttings } \\
\text { collected in Brandenburg/Havel and Potsdam.) }\end{array}$} \\
\hline \multirow[t]{2}{*}{$\begin{array}{l}\text { Municipal green- } \\
\text { waste collection } \\
\text { points }\end{array}$} & $d_{r}^{\mathrm{a}}$ & $C_{\text {tour, } r}{ }^{\mathrm{b}}$ & $\begin{array}{c}\text { Biomass } \\
\text { potentials }^{i}\end{array}$ & $\begin{array}{l}\text { Biomass } \\
\text { scenario } \\
\text { allocation }^{\mathrm{j}}\end{array}$ & tour $_{r}^{\mathrm{h}}$ & $C_{\text {trans }, r}{ }^{\mathbf{f}}$ & Total km km $^{\mathrm{g}}$ \\
\hline & $\mathrm{km}$ & $€ /$ tour & $\mathrm{Mg}$ FM/a & $\mathrm{Mg}$ FM/a & $\#$ & $€ / \mathrm{a}$ & $\mathrm{km}$ \\
\hline Brieselang & 12.3 & 143 & 2,159 & 1,928 & 138 & 19,667 & 3,387 \\
\hline Dallgow-Döberitz & 20.1 & 165 & 1,438 & 1,284 & 92 & 15,153 & 3,688 \\
\hline Falkensee, Stadt & 20.3 & 166 & 4,511 & 4,028 & 288 & 47,694 & 11,681 \\
\hline Friesack, Stadt & 27.1 & 185 & 863 & 770 & 55 & 10,191 & 2,981 \\
\hline Havelaue & 47.9 & 245 & 665 & 594 & 42 & 10,395 & 4,066 \\
\hline Ketzin, Stadt & 17.5 & 158 & 2,594 & 2,316 & 165 & 26,100 & 5,791 \\
\hline Märkisch Luch & 17.2 & 157 & 521 & 465 & 33 & 5,212 & 1,143 \\
\hline Milower Land & 40.1 & 223 & 1,521 & 1,358 & 97 & 21,583 & 7,777 \\
\hline Nauen, Stadt & 3.2 & 117 & 4,060 & 3,625 & 259 & 30,225 & 1,657 \\
\hline
\end{tabular}

Table continues on next page. 
Table 6 continued

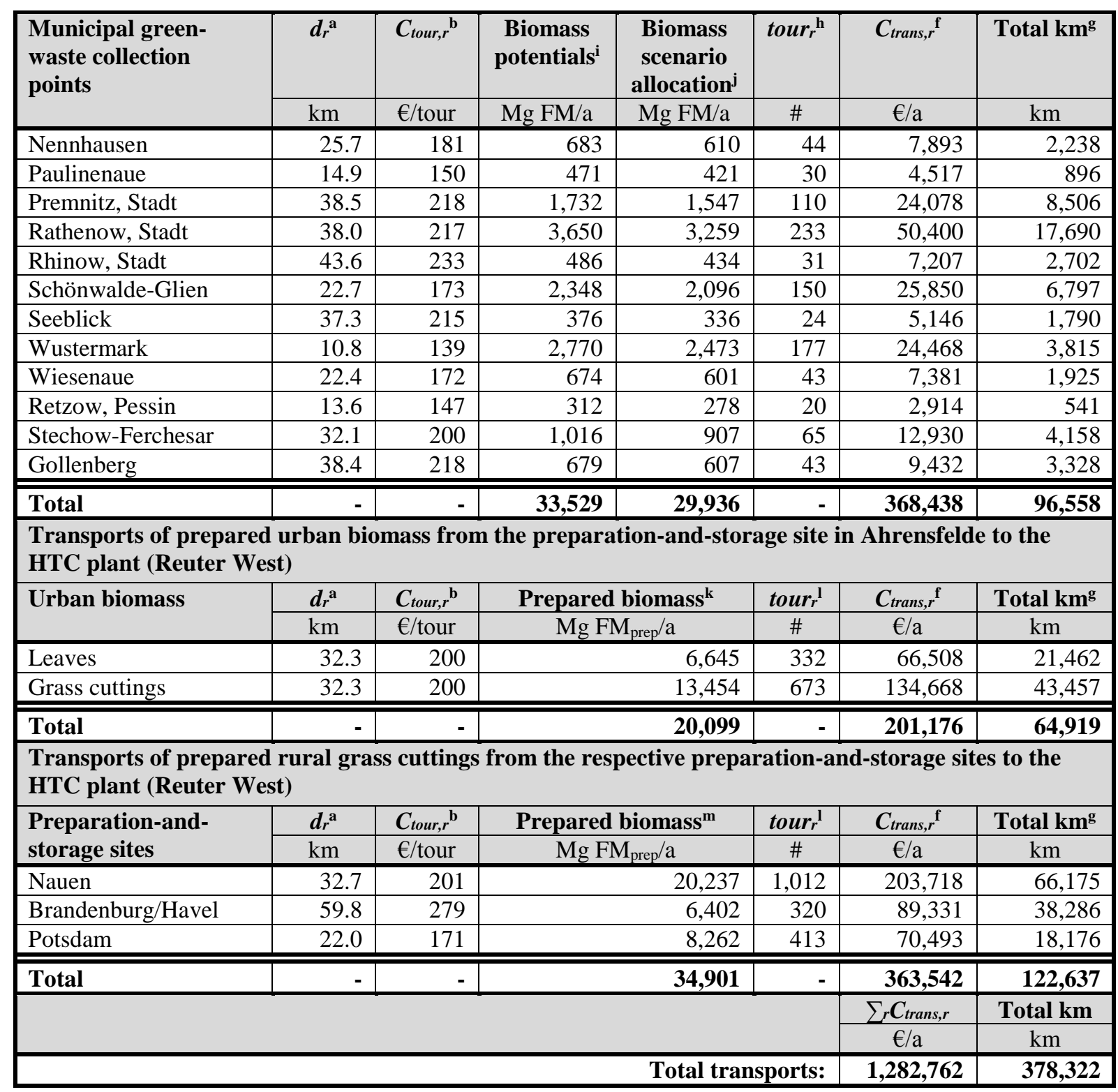

Sources:

a) Own calculation, based on Google Maps.

b) Own calculation, based on equation (10).

c) Own assumption, distributing the respective total biomass potentials of urban leaves (11,009 Mg FM/a, Vogt et al. 2012: 123) and grass cuttings (15,862 Mg FM/a, Vogt et al. 2012: 125) evenly across the twelve private gardening and landscaping firms.

d) Own calculation, downward-adjusting the potentials of urban leaves (grass cuttings) accruing at the single private gardening and landscaping firms proportionally to the downward-adjustment of the total potential of urban leaves (grass cuttings) of the private gardening and landscaping firms (see Table 1).

e) Own calculation, dividing the allocated biomass by the biomass load (before baling) of $10 \mathrm{Mg} /$ tour (Table 4).

f) Own calculation, based on equation (9).

g) Own calculation, multiplying $2 d_{r}$ by tour $_{r}$.

h) Own calculation, dividing the allocated biomass by the biomass load (before baling) of $14 \mathrm{Mg} /$ tour (Table 4).

i) Derived from the theoretical green-waste potentials provided by Zentner (2012), assuming that the technical biomass potentials are half of the corresponding theoretical potentials and that grass cuttings account for $75 \%$ of all collected green waste.

j) Own calculation, downward-adjusting the potentials of rural grass cuttings accruing at the single municipal green-waste collection points proportionally to the downward-adjustment of the total potential of rural grass cuttings in Havelland (see Table 1). 
k) Own calculation, multiplying the total allocated urban leaves (9,829 Mg FM/a, Table 1) and grass cuttings $(14,162 \mathrm{Mg} \mathrm{FM} / \mathrm{a}$, Table 1) by their respective share of prepared biomass (67.6\% for urban leaves and $95.0 \%$ for urban grass cuttings, Table 2).

1) Own calculation, dividing the prepared biomass by the biomass load (after baling) of $20 \mathrm{Mg} /$ tour (Table 4).

m) Own calculation, multiplying the rural grass cuttings allocated to the respective preparation-and-storage site by their share of prepared biomass $(67.6 \%$, Table 2$)$.

Notes: Values rounded. - Not applicable.

Table 7: Transport Distances and Costs in the Rural HTC Scenario

\begin{tabular}{|c|c|c|c|c|c|c|c|}
\hline \multicolumn{8}{|c|}{$\begin{array}{l}\text { Transports of unprepared rural grass cuttings from the municipal green-waste collection points to the } \\
\text { respective preparation-and-storage sites }\end{array}$} \\
\hline \multirow[t]{2}{*}{$\begin{array}{l}\text { Municipal green- } \\
\text { waste collection } \\
\text { points }\end{array}$} & $d_{r}{ }^{\mathrm{a}}$ & $C_{\text {tour }, r^{\mathbf{b}}}$ & $\begin{array}{c}\text { Biomass } \\
\text { potentials }\end{array}$ & $\begin{array}{c}\text { Biomass } \\
\text { scenario } \\
\text { allocation }^{d} \\
\end{array}$ & tour $_{r}^{\mathrm{e}}$ & $C_{\text {trans, }, r} \mathbf{f}$ & Total km ${ }^{\mathrm{g}}$ \\
\hline & $\mathrm{km}$ & $€ /$ tour & $\mathrm{Mg} \mathrm{FM} / \mathrm{a}$ & Mg FM/a & $\#$ & $€ / \mathrm{a}$ & $\mathrm{km}$ \\
\hline \multicolumn{8}{|c|}{$\begin{array}{l}\text { Transports from the municipal green-waste collection points in Potsdam-Mittelmark to the preparation- } \\
\text { and-storage site in Werder }\end{array}$} \\
\hline "Beelitz, Stadt & 23.0 & 174 & 2,836 & 2,696 & 193 & 33,420 & 8,860 \\
\hline Beetzsee & 34.4 & 206 & 605 & 575 & 41 & 8,467 & 2,825 \\
\hline Belzig, Stadt & 42.0 & 228 & 2,967 & 2,821 & 202 & 45,949 & 16,928 \\
\hline Bensdorf & 43.3 & 232 & 411 & 391 & 28 & 6,477 & 2,421 \\
\hline Borkheide & 23.0 & 174 & 632 & 601 & 43 & 7,453 & 1,976 \\
\hline Borkwalde & 19.1 & 162 & 234 & 223 & 16 & 2,583 & 608 \\
\hline Brück, Stadt & 29.1 & 191 & 1,255 & 1,193 & 85 & 16,283 & 4,962 \\
\hline Golzow & 30.8 & 196 & 342 & 326 & 23 & 4,555 & 1,433 \\
\hline Görzke & 52.1 & 257 & 431 & 409 & 29 & 7,516 & 3,048 \\
\hline Groß Kreutz (Havel) & 11.0 & 139 & 2,393 & 2,276 & 163 & 22,612 & 3,576 \\
\hline Havelsee, Stadt & 40.6 & 224 & 873 & 830 & 59 & 13,278 & 4,813 \\
\hline Kleinmachnow & 25.8 & 182 & 1,751 & 1,666 & 119 & 21,598 & 6,139 \\
\hline Kloster Lehnin & 19.3 & 163 & 3,059 & 2,909 & 208 & 33,852 & 8,021 \\
\hline Linthe & 32.9 & 202 & 544 & 517 & 37 & 7,461 & 2,431 \\
\hline Michendorf & 15.4 & 152 & 2,630 & 2,501 & 179 & 27,105 & 5,503 \\
\hline Niemegk, Stadt & 42.4 & 229 & 709 & 674 & 48 & 11,039 & 4,085 \\
\hline Nuthetal & 18.9 & 162 & 1,342 & 1,276 & 91 & 14,748 & 3,446 \\
\hline Planebruch & 28.8 & 190 & 369 & 351 & 25 & 4,769 & 1,444 \\
\hline Planetal & 39.1 & 220 & 385 & 366 & 26 & 5,744 & 2,045 \\
\hline Rosenau & 46.1 & 240 & 417 & 397 & 28 & 6,794 & 2,613 \\
\hline Roskow & 21.4 & 169 & 545 & 518 & 37 & 6,256 & 1,585 \\
\hline Schwielowsee & 7.6 & 129 & 2,302 & 2,190 & 156 & 20,229 & 2,377 \\
\hline Seddiner See & 21.4 & 169 & 641 & 610 & 44 & 7,356 & 1,864 \\
\hline Stahnsdorf & 24.9 & 179 & 3,790 & 3,605 & 257 & 46,078 & 12,822 \\
\hline Teltow, Stadt & 28.8 & 190 & 2,197 & 2,089 & 149 & 28,373 & 8,595 \\
\hline Treuenbrietzen, Stadt & 39.3 & 220 & 1,724 & 1,639 & 117 & 25,792 & 9,204 \\
\hline Werder (Havel), Stadt & 4.4 & 120 & 4,102 & 3,901 & 279 & 33,481 & 2,452 \\
\hline Wiesenburg/Mark & 52.5 & 258 & 1,795 & 1,707 & 122 & 31,478 & 12,805 \\
\hline Wusterwitz & 40.6 & 224 & 554 & 527 & 38 & 8,426 & 3,054 \\
\hline Ziesar, Stadt & 53.4 & 261 & 878 & 835 & 60 & 15,550 & 6,370 \\
\hline Beetzseeheide & 29.1 & 191 & 690 & 656 & 47 & 8,947 & 2,726 \\
\hline Mühlenfließ & 37.6 & 215 & 911 & 866 & 62 & 13,329 & 4,654 \\
\hline Buckautal, Gräben & 53.4 & 261 & 537 & 510 & 36 & 9,504 & 3,893 \\
\hline Wollin, Wenzlow & 40.6 & 224 & 494 & 469 & 34 & 7,509 & 2,722 \\
\hline Total & - & - & 45,346 & 43,123 & - & 564,011 & 162,300 \\
\hline
\end{tabular}

Table continues on next page. 


\section{Table 7 continued}

\begin{tabular}{|c|c|c|c|c|c|c|c|}
\hline \multicolumn{8}{|c|}{$\begin{array}{l}\text { Transports from the municipal green-waste collection points in Teltow-Fläming to the preparation-and- } \\
\text { storage site in Ludwigsfelde }\end{array}$} \\
\hline Am Mellensee & 19.9 & 165 & 1,137 & 1,082 & 77 & 12,719 & 3,075 \\
\hline Baruth/Mark, Stadt & 37.3 & 215 & 2,584 & 2,458 & 176 & 37,658 & 13,095 \\
\hline Blankenfelde-Mahlow & 13.5 & 146 & 5,653 & 5,376 & 384 & 56,169 & 10,368 \\
\hline Dahme/Mark, Stadt & 55.0 & 265 & 1,187 & 1,129 & 81 & 21,394 & 8,871 \\
\hline Großbeeren & 8.3 & 131 & 1,673 & 1,591 & 114 & 14,931 & 1,887 \\
\hline Jüterbog, Stadt & 40.8 & 225 & 2,660 & 2,530 & 181 & 40,582 & 14,746 \\
\hline Luckenwalde, Stadt & 27.8 & 187 & 2,616 & 2,488 & 178 & 33,281 & 9,881 \\
\hline Ludwigsfelde, Stadt & 1.7 & 112 & 3,729 & 3,546 & 253 & 28,478 & 861 \\
\hline Niedergörsdorf & 47.5 & 244 & 2,059 & 1,958 & 140 & 34,096 & 13,287 \\
\hline Niederer Fläming & 47.6 & 244 & 890 & 846 & 60 & 14,752 & 5,754 \\
\hline Nuthe-Urstromtal & 24.3 & 177 & 2,312 & 2,199 & 157 & 27,839 & 7,633 \\
\hline Rangsdorf & 16.1 & 154 & 1,867 & 1,775 & 127 & 19,490 & 4,082 \\
\hline Trebbin, Stadt & 11.5 & 141 & 2,282 & 2,170 & 155 & 21,785 & 3,565 \\
\hline Zossen, Stadt & 19.4 & 163 & 9,076 & 8,631 & 617 & 100,607 & 23,920 \\
\hline Dahmetal, Ihlow & 52.8 & 259 & 482 & 459 & 33 & 8,485 & 3,460 \\
\hline Total & - & - & 40,210 & 38,238 & - & 472,268 & 124,488 \\
\hline \multicolumn{8}{|c|}{$\begin{array}{l}\text { Transports of prepared rural grass cuttings from the preparation-and-storage sites to the HTC plant in } \\
\text { Jühnsdorf }\end{array}$} \\
\hline \multirow{2}{*}{$\begin{array}{l}\text { Preparation-and- } \\
\text { storage sites }\end{array}$} & $d_{r}^{\mathrm{a}}$ & $C_{\text {tour }, r^{\mathbf{b}}}$ & \multicolumn{2}{|c|}{ Prepared biomass $^{\text {h }}$} & tour $_{r}^{\mathrm{i}}$ & $C_{\text {trans }, r}{ }^{f}$ & Total km ${ }^{\mathrm{g}}$ \\
\hline & $\mathrm{km}$ & $€ /$ tour & \multicolumn{2}{|c|}{$\mathrm{Mg} \mathrm{FM}_{\text {prep }} / \mathrm{a}$} & $\#$ & $€ / \mathrm{a}$ & $\mathrm{km}$ \\
\hline Werder & 42.0 & 228 & \multicolumn{2}{|c|}{29,151} & 1,458 & 332,329 & 122,434 \\
\hline Ludwigsfelde & 11.6 & 141 & \multicolumn{2}{|r|}{25,849} & 1,292 & 182,002 & 29,985 \\
\hline Total & - & - & \multicolumn{2}{|r|}{55,000} & - & 514,331 & 152,419 \\
\hline \multicolumn{8}{|c|}{ Transports of rural HTC coal from the HTC plant in Jühnsdorf to the Reuter West CHP plant } \\
\hline \multirow[t]{2}{*}{ HTC plant } & $d_{r}^{\mathrm{a}}$ & $C_{\text {tour }, r^{\mathbf{b}}}$ & \multicolumn{2}{|c|}{ HTC coal $^{j}$} & tour $_{r}^{\mathrm{k}}$ & $C_{\text {trans }, r} \mathbf{f}$ & Total km km $^{\mathrm{g}}$ \\
\hline & $\mathrm{km}$ & $€ /$ tour & \multicolumn{2}{|c|}{$\mathrm{Mg} \mathrm{HTC} \mathrm{coal/a}$} & \# & $€ / \mathrm{a}$ & $\mathrm{km}$ \\
\hline Jühnsdorf & 33.7 & 204 & \multicolumn{2}{|c|}{19,852} & 1,103 & 225,212 & 74,335 \\
\hline \multirow[t]{4}{*}{ Total } & - & - & \multicolumn{2}{|r|}{19,852} & - & 225,212 & 74,335 \\
\hline & & & & & & $\sum_{r} C_{\text {trans }, r}$ & Total km \\
\hline & & & & & & $€ / \mathrm{a}$ & $\mathrm{km}$ \\
\hline & & & \multicolumn{3}{|c|}{ Total transports: } & $1,775,822$ & 513,541 \\
\hline
\end{tabular}

Sources:

a) Own calculation, based on Google Maps.

b) Own calculation, based on equation (10).

c) Derived from the theoretical green-waste potentials provided by Zentner (2012), assuming that the technical biomass potentials are half of the corresponding theoretical potentials and that grass cuttings account for $75 \%$ of all collected green waste.

d) Own calculation, downward-adjusting the biomass potentials accruing at the municipal green-waste collection points proportionally to the downward-adjustment of the respective total biomass potentials in PotsdamMittelmark and Teltow-Fläming (see Table 1).

e) Own calculation, dividing the allocated biomass by the biomass load (before baling) of $14 \mathrm{Mg} /$ tour (Table 4).

f) Own calculation, based on equation (9).

g) Own calculation, multiplying $2 d_{r}$ by tour $_{r}$.

h) Own calculation, multiplying the total allocated biomass in Potsdam-Mittelmark and Teltow-Fläming, respectively, by the share of prepared biomass for rural grass cuttings (67.6\%, Table 2).

i) Own calculation, dividing the prepared biomass by the biomass load (after baling) of $20 \mathrm{Mg} /$ tour (Table 4).

j) Own calculation, multiplying the total allocated biomass in the rural scenario $(81,361 \mathrm{Mg}$ FM/a, Table 1) by the yield of HTC coal obtained from that biomass (24.4\%, Table 2).

k) Own calculation, dividing the amount of HTC coal by the assumed load of $18 \mathrm{Mg}$ /tour (Table 4).

Notes: Values rounded. - Not applicable. 
Table 8: Transport Distances and Costs in the Urban Reference Scenario

\begin{tabular}{|c|c|c|c|c|c|c|}
\hline \multicolumn{7}{|c|}{ Transports of urban feedstocks to local composting facilities } \\
\hline \multirow[t]{2}{*}{ Feedstocks } & $d_{r}^{\mathrm{a}}$ & $C_{t o u r, r}{ }^{\mathbf{b}}$ & $\begin{array}{c}\text { Biomass scenario } \\
\text { allocation }^{c}\end{array}$ & tour $_{r}^{\mathrm{d}}$ & $C_{\text {trans }, r} \mathbf{e}^{\mathrm{e}}$ & Total km km $^{\mathrm{f}}$ \\
\hline & $\mathrm{km}$ & $€ /$ tour & $\mathrm{Mg}$ FM/a & $\#$ & $€ / \mathrm{a}$ & $\mathrm{km}$ \\
\hline \multicolumn{7}{|l|}{$B S R$} \\
\hline Urban leaves & 30.0 & 194 & 48,108 & 4,811 & 931,323 & 288,648 \\
\hline Urban grass cuttings & 30.0 & 194 & 4,758 & 340 & 65,793 & 20,391 \\
\hline Total & - & - & 52,866 & - & 997,116 & 309,039 \\
\hline \multicolumn{7}{|l|}{ Parks departments } \\
\hline U Urban leaves & 30.0 & 194 & 6,695 & 670 & 129,614 & 40,172 \\
\hline Urban grass cuttings & 30.0 & 194 & 14,140 & 1,010 & 195,524 & 60,600 \\
\hline Total & - & - & 20,835 & - & 325,138 & 100,771 \\
\hline \multicolumn{7}{|c|}{ Transports of compost to locations for field spreading } \\
\hline \multirow{2}{*}{$\begin{array}{l}\text { Compost derived } \\
\text { from }\end{array}$} & $d_{r}{ }^{\mathbf{a}}$ & $C_{\text {tour }, r^{\mathbf{b}}}$ & Compost $^{\mathrm{g}}$ & tour $_{r}^{\mathrm{h}}$ & $C_{\text {trans, } r} \mathrm{e}^{\mathrm{e}}$ & Total km $\mathbf{~ f ~}^{\mathrm{f}}$ \\
\hline & $\mathrm{km}$ & $€ /$ tour & Mg compost/a & $\#$ & $€ / \mathrm{a}$ & $\mathrm{km}$ \\
\hline Urban leaves & 20.0 & 165 & 21,921 & 1,096 & 180,752 & 43,843 \\
\hline Urban grass cuttings & 20.0 & 165 & 3,402 & 170 & 28,048 & 6,803 \\
\hline \multirow[t]{4}{*}{ Total } & - & - & 25,323 & - & 208,800 & $\overline{50,646}$ \\
\hline & & & & & $\sum_{r} \boldsymbol{C}_{\text {trans }, r}$ & Total km \\
\hline & & & & & $€ / \mathrm{a}$ & $\mathrm{km}$ \\
\hline & & & \multicolumn{2}{|c|}{ Total transports: } & $1,531,054$ & 460,456 \\
\hline
\end{tabular}

Sources:

a) Own assumption.

b) Own calculation, based on equation (10).

c) Table 1.

d) Own calculation, dividing the allocated leaves [grass cuttings] by the assumed biomass load (before baling) of $10 \mathrm{Mg} /$ tour [14 Mg/tour] (Table 4).

e) Own calculation, based on equation (9).

f) Own calculation, multiplying $2 d_{r}$ by tour $r$.

g) Own calculation, multiplying the allocated leaves [grass cuttings] by their compost yield of $40.0 \%$ [18.0\%] (Table 2).

h) Own calculation, dividing the amount of compost by the assumed compost load of $20 \mathrm{Mg} / \mathrm{tour}$ (Table 4).

Notes: Values rounded. - Not applicable. 
Table 9: Transport Distances and Costs in the Rural-Urban Reference Scenario

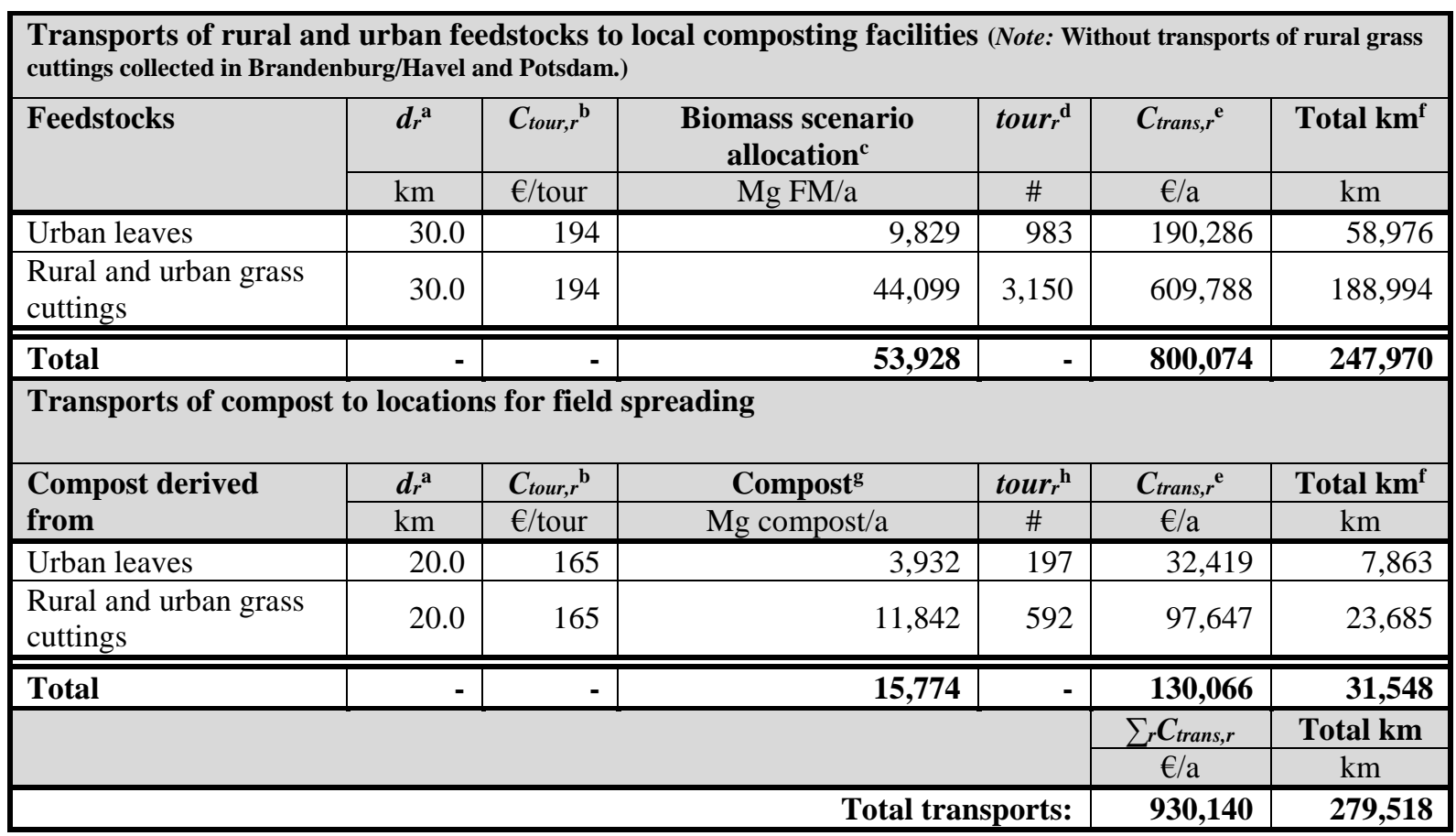

Sources:

a) Own assumption.

b) Own calculation, based on equation (10).

c) Table 1 . The grass cuttings are net of the rural grass cuttings accruing in Brandenburg/Havel (9,471 Mg FM/a) and Potsdam (12,222 Mg FM/a) since these are already collected at local composting facilities (Section 2.1.2).

d) Own calculation, dividing the allocated leaves [grass cuttings] by the assumed biomass load (before baling) of $10 \mathrm{Mg} /$ tour [14 Mg/tour] (Table 4).

e) Own calculation, based on equation (9).

f) Own calculation, multiplying $2 d_{r}$ by tour .

g) Own calculation, multiplying the allocated leaves [grass cuttings] by their compost yield of $40.0 \%$ [18.0\%] (Table 2). For the computation of the compost amounts, the grass cuttings are inclusive of the rural grass cuttings accruing in Brandenburg/Havel (9,471 Mg FM/a) and Potsdam (12,222 Mg FM/a) (Table 1).

h) Own calculation, dividing the amount of compost by the assumed compost load of $20 \mathrm{Mg} / \mathrm{tour}$ (Table 4).

Notes: Values rounded. - Not applicable. 
Table 10: Transport Distances and Costs in the Rural Reference Scenario

\begin{tabular}{|c|c|c|c|c|c|c|}
\hline \multicolumn{7}{|c|}{ Transports of rural feedstocks to local composting facilities } \\
\hline \multirow[t]{2}{*}{ Feedstocks } & $d_{r}{ }^{a}$ & $C_{\text {tour }, r^{\mathbf{b}}}$ & $\begin{array}{c}\text { Biomass scenario } \\
\text { allocation }^{\mathrm{c}}\end{array}$ & tour $_{r}^{\mathrm{d}}$ & $C_{\text {trans,r }} \mathbf{e}^{\mathrm{e}}$ & Total km km $^{2}$ \\
\hline & $\mathrm{km}$ & $€ /$ tour & $\mathrm{Mg} \mathrm{FM/a}$ & $\#$ & $€ / \mathrm{a}$ & $\mathrm{km}$ \\
\hline Rural grass cuttings & 30.0 & 194 & 81,361 & 5,811 & $1,125,048$ & 348,690 \\
\hline Total & - & - & 81,361 & - & $1,125,048$ & 348,690 \\
\hline \multicolumn{7}{|c|}{ Transports of compost to locations for field spreading } \\
\hline \multirow{2}{*}{$\begin{array}{l}\text { Compost derived } \\
\text { from }\end{array}$} & $d_{r}^{\mathrm{a}}$ & $C_{\text {tour }, r^{b}}$ & Compost $^{\mathrm{g}}$ & tour $_{r}^{\mathrm{h}}$ & $C_{\text {trans }, r} \mathrm{e}^{\mathrm{e}}$ & Total km ${ }^{\mathrm{f}}$ \\
\hline & $\mathrm{km}$ & $€ /$ tour & Mg compost/a & $\#$ & $€ / \mathrm{a}$ & $\mathrm{km}$ \\
\hline Rural grass cuttings & 20.0 & 165 & 14,645 & 732 & 120,755 & 29,290 \\
\hline \multirow[t]{4}{*}{ Total } & - & - & 14,645 & - & 120,755 & 29,290 \\
\hline & & & & & $\sum r C_{\text {trans }, r}$ & Total km \\
\hline & & & & & $€ / \mathrm{a}$ & $\mathrm{km}$ \\
\hline & & & Total tra & sports: & $\mathbf{1 , 2 4 5 , 8 0 3}$ & 377,980 \\
\hline
\end{tabular}

Sources:

a) Own assumption.

b) Own calculation, based on equation (10).

c) Table 1.

d) Own calculation, dividing the allocated rural grass cuttings by the biomass load (before baling) of $14 \mathrm{Mg} / \mathrm{tour}$ (Table 4).

e) Own calculation, based on equation (9).

f) Own calculation, multiplying $2 d_{r}$ by tour .

g) Own calculation, multiplying the allocated rural grass cuttings by their compost yield of $18.0 \%$ (Table 2).

h) Own calculation, dividing the amount of compost by the assumed compost load of $20 \mathrm{Mg} /$ tour (Table 4).

Notes: Values rounded. - Not applicable. 
Table 11: Emission Factors

\begin{tabular}{|c|c|c|}
\hline \multicolumn{3}{|c|}{ HTC scenarios } \\
\hline Fuel & Stage & $\begin{array}{c}\text { Value } \\
\left(\mathrm{g} \mathrm{CO}_{2} \mathrm{e} / \mathrm{kWh}\right) \\
\end{array}$ \\
\hline \multirow{3}{*}{ Hard coal (heat-related; CHP plant) ${ }^{\mathrm{a}}$} & Combustion & 191.2 \\
\hline & Pre-combustion & 42.3 \\
\hline & Total & 233.5 \\
\hline \multirow{3}{*}{ Hard coal (electricity-related; CHP plant) ${ }^{\mathrm{a}}$} & Combustion & 503.3 \\
\hline & Pre-combustion & 25.7 \\
\hline & Total & 529.0 \\
\hline \multicolumn{2}{|l|}{ Electricity (waste incineration) $^{\mathrm{a}}$} & 417.6 \\
\hline \multicolumn{2}{|l|}{ Electricity (mix Germany) ${ }^{\mathrm{b}}$} & 629.0 \\
\hline \multicolumn{2}{|l|}{ Diesel fuel $^{\mathrm{c}}$} & 314.0 \\
\hline \multicolumn{2}{|l|}{\begin{tabular}{|l} 
Natural gas \\
\end{tabular}} & 228.0 \\
\hline \multicolumn{3}{|c|}{ Reference scenarios } \\
\hline Emissions & Feedstock & $\begin{array}{c}\text { Value } \\
\left(\mathrm{kg} \mathrm{CO}_{2} \mathrm{e} / \mathrm{Mg} \mathrm{FM} \text { input }\right) \\
\end{array}$ \\
\hline \multirow{2}{*}{$\mathrm{CH}_{4}$ and $\mathrm{N}_{2} \mathrm{O}$ emissions from composting ${ }^{\mathrm{d}}$} & Leaves & 77.0 \\
\hline & Grass cuttings & 43.0 \\
\hline \multirow{2}{*}{$\begin{array}{l}\text { Emissions saved by compost substituting for mineral } \\
\text { fertilizers in soil applications }{ }^{\mathrm{d}}\end{array}$} & Leaves & -94.0 \\
\hline & Grass cuttings & -45.0 \\
\hline
\end{tabular}

Sources:

a) Fritsche and Rausch (2008: 20-21). Pre-combustion emissions include emissions related to the extraction, transportation, conditioning, and distribution of hard coal, as well as to plant constructions (Fritsche and Rausch 2008; see Figure 4).

b) Vogt et al. (2012: 6).

c) $\operatorname{ICU}(2011: 28)$.

d) ICU (unpublished data), based on Knappe et al. (2012). The composting-related emission factors reflect the conditions of open-windrow composting, as predominant in the surroundings of Berlin (Vogt et al. 2012). 
Table 12: Life-Cycle Emissions

\begin{tabular}{|c|c|c|c|c|c|c|}
\hline \multirow[b]{3}{*}{ Emissions } & \multicolumn{3}{|c|}{ HTC scenarios } & \multicolumn{3}{|c|}{ Reference scenarios } \\
\hline & Urban & $\begin{array}{l}\text { Rural- } \\
\text { urban }\end{array}$ & Rural & Urban & $\begin{array}{l}\text { Rural- } \\
\text { urban }\end{array}$ & Rural \\
\hline & \multicolumn{3}{|c|}{$\mathrm{kg} \mathrm{CO} \mathrm{CO}_{2} \mathrm{e} / \mathrm{Mg} \mathrm{FM}$ input } & \multicolumn{3}{|c|}{$\mathrm{kg} \mathrm{CO} 2 \mathrm{e} / \mathrm{Mg} \mathrm{FM}$ input } \\
\hline Transportation $^{\mathrm{a}}$ & 12.6 & 6.2 & 7.9 & 7.8 & 4.6 & 5.8 \\
\hline Bailing and storage $^{\mathrm{b}}$ & 3.5 & 3.5 & 3.5 & - & - & - \\
\hline $\begin{array}{l}\text { Auxiliary energy } \\
\text { requirements }\end{array}$ & 36.1 & 41.6 & 44.2 & 8.1 & 8.1 & 8.1 \\
\hline $\begin{array}{l}\text { Hard-coal combustion (pre- } \\
\text { combustion) }^{\mathrm{d}}\end{array}$ & - & - & - & 44.2 & 32.0 & 33.9 \\
\hline $\begin{array}{l}\text { Hard-coal combustion } \\
\text { (combustion-related) }^{\mathrm{e}}\end{array}$ & - & - & - & 306.8 & 308.4 & 326.2 \\
\hline $\begin{array}{l}\mathrm{CH}_{4} \text { and } \mathrm{N}_{2} \mathrm{O} \text { emissions from } \\
\text { composting }\end{array}$ & - & - & - & 68.3 & 47.4 & 43.0 \\
\hline Mineral-fertilizer substitution $^{\mathrm{g}}$ & - & - & - & -81.4 & -51.4 & -45.0 \\
\hline Total emissions & \multicolumn{3}{|c|}{$\overline{E_{H T C}}$} & \multicolumn{3}{|c|}{$E_{\text {Reference }}$} \\
\hline $\mathrm{kg} \mathrm{CO}_{2} \mathrm{e} / \mathrm{Mg} \mathrm{FM}$ input ${ }^{\mathrm{h}}$ & 52.2 & 51.3 & 55.5 & 353.8 & 349.2 & 372.0 \\
\hline $\mathrm{MgCO}_{2} \mathrm{e} / \mathrm{a}^{\mathrm{i}}$ & 3,844 & 3,878 & 4,517 & 26,074 & 26,410 & 30,266 \\
\hline Difference & \multicolumn{3}{|c|}{$E_{\text {Reference }}-\boldsymbol{E}_{H T C}$} & \multicolumn{3}{|c|}{-} \\
\hline $\mathrm{kg} \mathrm{CO}_{2} \mathrm{e} / \mathrm{Mg} \mathrm{FM}$ input ${ }^{\mathrm{h}}$ & 301.6 & 298.0 & 316.5 & - & - & - \\
\hline $\mathrm{MgCO}_{2} \mathrm{e} / \mathrm{a}^{\mathrm{h}}$ & 22,230 & 22,532 & 25,749 & - & - & - \\
\hline
\end{tabular}

Sources:

a) Own calculation, based on the diesel-fuel requirements for transportations from Table 3 and the diesel-fuel emissions from Table 11.

b) Own calculation, based on the diesel-fuel and electricity requirements for bailing and storage from Table 3 and the emissions from diesel fuel and electricity (mix Germany) from Table 11.

c) Own calculation, based on the auxiliary diesel-fuel, natural-gas, and electricity requirements from Table 3 and the respective emissions from Table 11. For HTC-coal drying, the urban HTC scenario uses electricity from the $B S R$ waste-incineration plant located at the site of the HTC plant, while the rural-urban HTC scenario uses electricity from hard coal combusted at the Reuter West CHP plant. In all other cases, electricity refers to the German mix.

d) Own calculation, based on the usable heat and electricity from HTC coal (Table 3) and the pre-combustion emissions resulting from the use of hard coal, both heat- and electricity related (Table 11). Pre-combustion emissions include emissions related to the extraction, transportation, conditioning, and distribution of hard coal, as well as to plant constructions (Fritsche and Rausch 2008; see Figure 4).

e) Own calculation, based on the usable heat and electricity from HTC coal (Table 3) and the combustion-related emissions resulting from the use of hard coal, both heat- and electricity related (Table 11).

f) Own calculation, based on the composting-related GHG emissions from Table 11 and the shares of leaves and grass cuttings from the second-last column of Table 1.

g) Own calculation, based on the emission savings from compost soil application due to the replacement of mineral fertilizers (Table 11), combined with the shares of leaves and grass cuttings from the second-last column of Table 1.

h) Own calculation.

i) Own calculation, multiplying the values in $\mathrm{kg} \mathrm{CO}_{2} \mathrm{e} / \mathrm{Mg} \mathrm{FM}$ input by the biomass (Mg FM/a) allocated to the respective scenario (Table 1) and dividing by 1,000 .

Notes: Values rounded. - Not applicable. 
Table 13: HTC-Related Costs and Revenues (without Transportation, Baling, Storage)

\begin{tabular}{|c|c|c|c|c|}
\hline Cost or revenue position & Unit & $\begin{array}{c}\text { Urban HTC } \\
\text { scenario } \\
\end{array}$ & $\begin{array}{c}\text { Rural-urban } \\
\text { HTC scenario } \\
\end{array}$ & $\begin{array}{c}\text { Rural HTC } \\
\text { scenario } \\
\end{array}$ \\
\hline \multicolumn{5}{|l|}{ Costs for biomass preparation } \\
\hline Biomass preparation (incl. electricity) ${ }^{\mathrm{a}}$ & \multirow{2}{*}{$€ / \mathrm{Mg} \mathrm{FM}$ input } & \multicolumn{3}{|c|}{15.0} \\
\hline Residue disposal after biomass preparation ${ }^{\mathrm{a}}$ & & \multicolumn{3}{|c|}{4.9} \\
\hline \multicolumn{5}{|l|}{ Capital-related costs } \\
\hline Total investment costs for an HTC plant ${ }^{\mathrm{b}}$ & $€$ & \multicolumn{3}{|c|}{$15,000,000$} \\
\hline \multicolumn{5}{|l|}{ Consumption-related costs } \\
\hline \multirow{2}{*}{ Electricity (for HTC-coal drying) ${ }^{\mathrm{c}}$} & $€ / \mathrm{kWh}$ & 0.028 & 0.028 & 0.0814 \\
\hline & $€ / M g$ FM input & 1.62 & 1.58 & 4.28 \\
\hline \multirow{2}{*}{ Natural gas ${ }^{\mathrm{d}}$} & $€ / \mathrm{kWh}$ & 0.03 & 0.03 & 0.03 \\
\hline & $€ / \mathrm{Mg}$ FM input & 1.03 & 1.00 & 0.93 \\
\hline \multirow{2}{*}{ Diesel fuel $^{\mathrm{e}}$} & $€ /$ liter & \multicolumn{3}{|c|}{1.12} \\
\hline & $€ / \mathrm{Mg}$ FM input & \multicolumn{3}{|c|}{0.34} \\
\hline \multirow{2}{*}{ Fresh water ${ }^{\mathrm{f}}$} & $€ / \mathrm{m}^{3}$ & 2.17 & 2.17 & 1.52 \\
\hline & $€ / \mathrm{Mg}$ FM input & 0.05 & 0.05 & 0.03 \\
\hline Wastewater treatment ${ }^{\mathrm{a}}$ & $€ / \mathrm{Mg}$ FM input & \multicolumn{3}{|c|}{1.5} \\
\hline \multicolumn{5}{|l|}{ Operation-related costs } \\
\hline Personnel $^{\mathrm{a}}$ & \multirow{2}{*}{$€ / \mathrm{Mg}$ FM input } & \multicolumn{3}{|c|}{2.8} \\
\hline Service and maintenance ${ }^{a}$ & & \multicolumn{3}{|c|}{2.8} \\
\hline \multicolumn{5}{|l|}{ Revenues } \\
\hline \multirow{2}{*}{$\begin{array}{l}\text { Sales of electricity from HTC-coal } \\
\text { combustion [for SLCA and abatement } \\
\text { costs] }\end{array}$} & $€ / \mathrm{kWh}$ & $\begin{array}{l}0.1029 \\
{[0.028]} \\
\end{array}$ & 0.028 & 0.028 \\
\hline & $€ / \mathrm{Mg}$ FM input & $\begin{array}{l}28.40 \\
{[7.73]}\end{array}$ & 11.84 & 12.53 \\
\hline \multirow{2}{*}{ Sales of heat from HTC-coal combustion ${ }^{\mathrm{h}}$} & $€ / \mathrm{kWh}$ & 0.03 & 0.03 & 0.03 \\
\hline & $€ / M g$ FM input & 26.34 & 15.00 & 15.86 \\
\hline $\begin{array}{l}\text { Tipping fees for green waste dropped off at } \\
\text { collection points }{ }^{\mathrm{i}}\end{array}$ & $€ / \mathrm{Mg}$ FM input & \multicolumn{3}{|c|}{120.0} \\
\hline $\begin{array}{l}\text { Tipping fees for third-party management of } \\
\text { green waste }^{\mathrm{j}}\end{array}$ & $€ / \mathrm{Mg}$ FM input & \multicolumn{3}{|c|}{20.0} \\
\hline
\end{tabular}

Sources:

a) SunCoal (2012: 5).

b) SunCoal (2012: 7).

c) Urban and rural-urban HTC scenarios: EEX (2017a), reflecting the 2016 average end-of-month base-load electricity spot-market price. Rural HTC scenario: Statista (2017a), referring to the 2014-2016 average electricity price for industrial customers. The values in $€ / \mathrm{kWh}$ are transformed into $€ / \mathrm{Mg} F M$ input by multiplying them by the respective $\mathrm{kWh} / \mathrm{Mg}$ FM input of electricity used for HTC-coal drying (Table 3 ).

d) Statistisches Bundesamt (2017a: 22), referring to the 2014-2016 average natural-gas price for industrial customers. The value in $€ / \mathrm{kWh}$ is transformed into $€ / \mathrm{Mg} F M$ input by multiplying it by the respective $\mathrm{kWh} / \mathrm{Mg}$ FM input of natural gas used for reactor heating (Table 3).

e) Statista (2017b), referring to the average German diesel price from April 2016 to April 2017. The value in $€ /$ liter is transformed into $€ / \mathrm{Mg}$ FM input by dividing it by the assumed $9.94 \mathrm{kWh} /$ liter diesel (Table 4) and multiplying it by $3.0 \mathrm{kWh} / \mathrm{Mg}$ FM input of diesel used for biomass feeding (Table 3).

f) Statistisches Bundesamt (2017b). The latest prices are given for 2013 . The values in $€ / \mathrm{m}^{3}$ are transformed into $€ / \mathrm{Mg}$ FM input by assuming that an HTC reactor uses $1,800 \mathrm{~m}^{3}$ of fresh water per year (SunCoal 2012:3) and by dividing them by the respective annual biomass inputs given in the last column of Table 1 .

g) Urban HTC scenario: § 42 EEG 2017 (Bundesgesetzblatt 2016), referring to biomass plants with an electrical capacity of $500 \mathrm{~kW}$ to $5 \mathrm{MW}$ installed before April 2017. Urban HTC scenario for SLCA and abatement costs as well as rural-urban and rural HTC scenarios: EEX (2017a), reflecting the 2016 average end-of-month baseload electricity spot-market price. The values in $€ / \mathrm{kWh}$ are transformed into $€ / \mathrm{Mg} F M$ input by multiplying them by the respective usable electricity from HTC coal (Table 3 ).

h) Gores et al. (2013: 23), referring to the heat retail price for district heating. The value in $€ / \mathrm{kWh}$ is transformed into $€ / \mathrm{Mg}$ FM input by multiplying it by the respective usable heat from HTC coal (Table 3 ). 
i) Own calculation, based on $€ 3$ per leaf sack (à $0.025 \mathrm{Mg} \mathrm{FM}$ ) dropped off at BSR recycling points (BSR 2017) and $15,855 \mathrm{Mg} \mathrm{FM} / \mathrm{a}$ of leaves collected through leaf sacks (Table 1).

j) SunCoal (2012: 2).

Note: Values rounded.

Table 14: Costs of Bailing and Storage

\begin{tabular}{|l|c|c|c|c|}
\hline & Unit & $\begin{array}{c}\text { Urban HTC } \\
\text { scenario }\end{array}$ & $\begin{array}{c}\text { Rural-urban } \\
\text { HTC scenario }\end{array}$ & $\begin{array}{c}\text { Rural HTC } \\
\text { scenario }\end{array}$ \\
\hline Levelized baling costs $\left(c_{\text {bale }}\right)^{\mathrm{a}}$ & $€ /$ bale & \multicolumn{3}{|c|}{4.00} \\
\hline Bale volume $\left(b_{\text {vol }}\right)^{\mathrm{b}}$ & $\mathrm{m}^{3}$ & \multicolumn{3}{|c|}{1.10} \\
\hline Bale density $\left(b_{\text {dens }}\right)^{\mathrm{b}}$ & $\mathrm{Mg} \mathrm{FM}_{\text {prep }} / \mathrm{m}^{3}$ & \multicolumn{3}{|c|}{0.65} \\
\hline Levelized overhead costs for storage $\left(c_{\text {over }}\right)^{\mathrm{c}}$ & $€ / \mathrm{Mg} \mathrm{FM}_{\text {prep }}$ & \multicolumn{3}{|c|}{5.20} \\
\hline Biomass after preparation $\left(m_{\text {prep }}\right)^{\mathrm{d}}$ & $\mathrm{Mg} \mathrm{FM}$ prep $/ \mathrm{a}$ & & $\mathbf{4 2 8 , 6 9 2}$ & $\mathbf{4 2 8 , 6 9 2}$ \\
\hline \hline Annual costs of bailing and storage $\left(\boldsymbol{C}_{\text {stor }}\right)^{\mathrm{e}}$ & $\boldsymbol{\epsilon} / \mathbf{a}$ & $\mathbf{4 2 8 , 6 9 2}$ & \multicolumn{3}{|c|}{} \\
\hline
\end{tabular}

Sources:

a) Eltrop et al. (2005: 216).

b) Vogt et al. (2012: 220), based on baling experiments with leaves.

c) Eltrop et al. (2005: 221).

d) Own calculation, multiplying the allocated biomass potentials in each scenario (Table 1) by their respective shares of prepared biomass (Table 2).

e) Own calculation, using equation (11).

Note: Values rounded.

Table 15: Cost Data for the Biomass CHP plant in the Urban HTC Scenario

\begin{tabular}{|c|c|c|}
\hline Cost position & Unit & Costs \\
\hline Capital-related costs (total investment costs) ${ }^{\mathrm{a}}$ & \multirow{13}{*}{$€$} & $\overline{16,958,000}$ \\
\hline Heating station & & $1,828,000$ \\
\hline Furnace and boiler & & $4,900,000$ \\
\hline Flue-gas cleaning & & 510,000 \\
\hline Ash container and conveyor & & 120,000 \\
\hline Fuel conveyor & & 800,000 \\
\hline Electric installations & & 670,000 \\
\hline Hydraulic installations & & 40,000 \\
\hline CHP module & & $4,100,000$ \\
\hline Fuel-storage unit & & 600,000 \\
\hline Weighbridge & & 100,000 \\
\hline Planning & & 720,000 \\
\hline Other investment costs & & $2,570,000$ \\
\hline Consumption-related costs ${ }^{b}$ & \multirow{5}{*}{$€ / \mathrm{a}$} & $\mathbf{3 7 6 , 3 1 0}$ \\
\hline Electricity consumption & & 65,495 \\
\hline Additional heat generation costs CHP & & 100,815 \\
\hline General consumption costs & & 110,000 \\
\hline Ash disposal & & 100,000 \\
\hline Operation-related costs ${ }^{\mathrm{c}}$ & \multirow{3}{*}{$€ / \mathrm{a}$} & 418,854 \\
\hline Personnel & & 203,854 \\
\hline Maintenance & & 215,000 \\
\hline
\end{tabular}

Sources:

a) Sum of the respective cost positions from Tables 4.3 and 4.5 from Obernberger and Thek (2004).

b) Sum of the respective cost positions from Tables 4.4 and 4.6 from Obernberger and Thek (2004). The electricity consumption is obtained by multiplying 2,339,092 kWh/a (Obernberger and Thek 2004: Table 4.2) by the 2016 average end-of-month base-load electricity spot-market price of $0.028 € / \mathrm{kWh}$ (EEX 2017a).

c) Sum of the respective cost positions from Tables 4.4 and 4.6 from Obernberger and Thek (2004).

Note: Values rounded. 
Table 16: Data for the Reuter West CHP Plant

\begin{tabular}{|c|c|c|c|c|}
\hline & Unit & \multicolumn{3}{|c|}{ Value } \\
\hline Total efficiency $\left(\eta_{t o t}\right)^{\mathrm{a}}$ & \multirow{3}{*}{$\%$} & \multicolumn{3}{|c|}{72} \\
\hline Electrical efficiency $^{\mathrm{a}}$ & & \multicolumn{3}{|c|}{33} \\
\hline Thermal efficiency $^{\mathrm{a}}$ & & \multicolumn{3}{|c|}{39} \\
\hline $\begin{array}{l}\text { Variable operating costs } \\
\text { (i.e. consumption-related costs) }^{\mathrm{b}}\end{array}$ & $€ / \mathrm{MWh}$ & \multicolumn{3}{|c|}{1.28} \\
\hline Fuel costs $\left(c_{f u e l} / \eta_{t o t}\right)^{\mathrm{c}}$ & $€ / M W h$ & \multicolumn{3}{|c|}{18.33} \\
\hline Fuel costs for hard coal $\left(c_{\text {fuel }}\right)^{\mathrm{d}}$ & $€ / \mathrm{MWh}_{\text {fuel }}$ & \multicolumn{3}{|c|}{13.20} \\
\hline Carbon costs $\left(c_{\mathrm{CO}_{2}}\right)^{\mathrm{e}}$ & $€ / M W h$ & \multicolumn{3}{|c|}{3.47} \\
\hline Price for emission allowances $\left(p_{\mathrm{CO}_{2}}\right)^{\mathrm{f}}$ & $€ / \mathrm{Mg} \mathrm{CO}_{2}$ & \multicolumn{3}{|c|}{5.00} \\
\hline Hard-coal emission factor $\left(f_{\mathrm{CO}_{2}}\right)^{\mathrm{g}}$ & $\mathrm{Mg} \mathrm{CO}_{2} \mathrm{e} / \mathrm{MWh}$ & \multicolumn{3}{|c|}{0.6945} \\
\hline $\begin{array}{l}\text { Total consumption-related costs [for SLCA } \\
\text { and abatement costs] }\end{array}$ & $€ / \mathbf{M W h}$ & \multicolumn{3}{|c|}{$\begin{array}{c}23.08 \\
{[19.61]}\end{array}$} \\
\hline $\begin{array}{l}\text { Fixed operating costs } \\
\text { (i.e. operation-related costs) }^{\mathrm{i}}\end{array}$ & $€ / \mathrm{MWh}$ & \multicolumn{3}{|c|}{3.93} \\
\hline \multirow[t]{2}{*}{ Total operation-related costs ${ }^{\mathrm{c}}$} & $€ / \mathbf{M W h}$ & \multicolumn{3}{|c|}{3.93} \\
\hline & Unit & $\begin{array}{c}\text { Urban } \\
\text { reference } \\
\text { scenario } \\
\end{array}$ & $\begin{array}{c}\text { Rural-urban } \\
\text { reference } \\
\text { scenario } \\
\end{array}$ & $\begin{array}{c}\text { Rural } \\
\text { reference } \\
\text { scenario } \\
\end{array}$ \\
\hline \multirow{2}{*}{$\begin{array}{l}\text { Sales of electricity from hard-coal } \\
\text { combustion }^{j}\end{array}$} & $€ / \mathrm{kWh}$ & \multicolumn{3}{|c|}{0.028} \\
\hline & €/Mg FM input & 14.81 & 11.84 & $\mathbf{1 2 . 5 3}$ \\
\hline \multirow{2}{*}{ Sales of heat from hard-coal combustion ${ }^{\mathrm{k}}$} & $€ / \mathrm{kWh}$ & \multicolumn{3}{|c|}{0.03} \\
\hline & €/Mg FM input & 18.75 & 15.00 & 15.86 \\
\hline
\end{tabular}

Sources:

a) Vogt et al. (2012: III).

b) Own calculation, based on Hobohm et al. (2011: 135), who assume consumption-related costs of $2 € / M W h$ for electricity generated at a total efficiency of $46 \%$. That is, $1.28 € / \mathrm{MWh}=2 € / \mathrm{MWh} \cdot 0.46 / 0.72$.

c) Own calculation.

d) Hobohm et al. (2011: 135), free power plant.

e) Own calculation, based on equation (12).

f) EEX (2017b), referring to the approximated 2016 average price for EU emission allowances traded in Germany at primary market auctions.

g) Table 11, sum of heat- and electricity-related emissions from hard-coal combustion.

h) Own calculation, excluding the carbon costs $\left(\mathrm{C}_{\mathrm{CO}_{2}}\right)$ for the SLCA and abatement-cost calculation.

i) Own calculation, derived as $2 \%$ of the annual specific investment costs of $1,400 € / \mathrm{kW}$ for newly installed conventional hard-coal-fired power plants with a total efficiency for electricity generation of 46\% (Hobohm et al. 2011: 135) and assuming 4,557 annual operating hours for the Reuter West CHP plant. The operating hours are based on the electricity capacity of the Reuter West CHP plant of $564 \mathrm{MW}_{\mathrm{el}}$ (Vattenfall 2017) and the 2012 electricity output of 2,570 gigawatt hours (Wikipedia 2017). That is, $3.93 € / \mathrm{MWh}=1,400 € / \mathrm{kW} \cdot 0.46 / 0.72$. $1,000 \cdot 0.02 / 4,557 \mathrm{~h}$.

j) EEX (2017a), reflecting the 2016 average end-of-month base-load electricity spot-market price. In the urban reference scenario, the value in $€ / \mathrm{kWh}$ is transformed into $€ / \mathrm{Mg} F M$ input by multiplying it by the usable energy from HTC coal (Table 3), times 33/72 to correct for the total (72\%) and electricity-related (33\%) efficiencies of the Reuter West CHP plant (Vogt et al. 2012: III). In the rural-urban and rural reference scenarios, the value in $€ / \mathrm{kWh}$ is transformed into $€ / \mathrm{Mg} F M$ input by directly multiplying it by the respective usable electricity from HTC coal (Table 3 ).

k) Gores et al. (2013: 23), referring to the heat retail price for district heating. In the urban reference scenario, the value in $€ / \mathrm{kWh}$ is transformed into $€ / \mathrm{Mg} \mathrm{FM}$ input by multiplying it by the usable energy from HTC coal (Table 3), times 39/72 to correct for the total (72\%) and thermal (39\%) efficiencies of the Reuter West CHP plant (Vogt et al. 2012: III). In the rural-urban and rural reference scenarios, the value in $€ / \mathrm{kWh}$ is transformed into $€ / \mathrm{Mg}$ FM input by directly multiplying it by the respective usable heat from HTC coal (Table 3 ).

Note: Values rounded. 
Table 17: Urban HTC Scenario

\begin{tabular}{|c|c|c|c|c|c|}
\hline & Unit & $\begin{array}{c}\text { LCC } \\
\text { (life cycle) } \\
\end{array}$ & $\begin{array}{c}\mathrm{LCC} \\
\text { (investor) } \\
\end{array}$ & $\overline{\text { SLCA }}$ & $\begin{array}{c}\text { Abatement } \\
\text { costs }\end{array}$ \\
\hline Capital-related costs: $C_{\theta^{a}}$ & $€$ & \multicolumn{4}{|c|}{$31,958,000$} \\
\hline & Value & $\overline{C F_{t, L C C}}$ & $C F_{t, \text { investor }}$ & $\begin{array}{c}C F_{t, L C C+}+ \\
C F_{t, S L C A} \\
\end{array}$ & $C F_{t, L C C}^{\prime}$ \\
\hline & $\begin{array}{l}€ / \mathrm{Mg} \mathrm{FM} \\
\text { input }\end{array}$ & \multicolumn{4}{|c|}{$€ / \mathrm{a}$} \\
\hline & (1) & (2) & (3) & (4) & (5) \\
\hline Transportation costs & - & $2,236,355$ & $2,236,355$ & $2,236,355$ & $2,236,355$ \\
\hline Biomass $^{\mathrm{b}}$ & - & $2,236,355$ & $2,236,355$ & $2,236,355$ & $2,236,355$ \\
\hline $\begin{array}{l}\text { Preparation, baling, and } \\
\text { storage costs }\end{array}$ & - & $1,895,345$ & $1,895,345$ & $1,895,345$ & $1,895,345$ \\
\hline $\begin{array}{l}\text { Biomass preparation } \\
\text { (including electricity) }^{\mathrm{c}}\end{array}$ & 15.0 & $1,105,517$ & $1,105,517$ & $1,105,517$ & $1,105,517$ \\
\hline Residue disposal $^{\mathrm{c}}$ & 4.9 & 361,136 & 361,136 & 361,136 & 361,136 \\
\hline Baling and storage $\left(C_{\text {stor }}\right)^{\mathrm{d}}$ & - & 428,692 & 428,692 & 428,692 & 428,692 \\
\hline Consumption-related costs & - & 710,907 & 710,907 & 710,907 & 710,907 \\
\hline $\begin{array}{l}\text { Electricity (for HTC-coal } \\
\text { drying) }\end{array}$ & 1.62 & 119,670 & 119,670 & 119,670 & 119,670 \\
\hline Natural gas ${ }^{\mathrm{c}}$ & 1.03 & 75,557 & 75,557 & 75,557 & 75,557 \\
\hline Diesel fuel $^{\mathrm{c}}$ & 0.34 & 24,913 & 24,913 & 24,913 & 24,913 \\
\hline Fresh water ${ }^{\mathrm{c}}$ & 0.05 & 3,906 & 3,906 & 3,906 & 3,906 \\
\hline Wastewater treatment ${ }^{\mathrm{c}}$ & 1.5 & 110,552 & 110,552 & 110,552 & 110,552 \\
\hline HTC-coal combustion $^{\mathrm{e}}$ & - & 376,310 & 376,310 & 376,310 & 376,310 \\
\hline Operation-related costs & - & $\mathbf{8 3 1 , 5 8 0}$ & $\mathbf{8 3 1 , 5 8 0}$ & 831,580 & $\mathbf{8 3 1 , 5 8 0}$ \\
\hline Personnel $^{\mathrm{c}}$ & 2.8 & 206,363 & 206,363 & 206,363 & 206,363 \\
\hline Service and maintenance ${ }^{c}$ & 2.8 & 206,363 & 206,363 & 206,363 & 206,363 \\
\hline HTC-coal combustion $^{\mathrm{e}}$ & - & 418,854 & 418,854 & 418,854 & 418,854 \\
\hline Damage costs ${ }^{\mathrm{f}}$ & - & - & - & 269,106 & - \\
\hline Revenues & - & $12,878,552$ & $10,795,036$ & $11,355,130$ & $2,510,992$ \\
\hline $\begin{array}{l}\text { Sales of electricity [for SLCA } \\
\text { and abatement costs] }\end{array}$ & $\begin{array}{l}28.40 \\
{[7.73]}\end{array}$ & $2,092,925$ & $2,092,925$ & 569,503 & 569,503 \\
\hline Sales of heat $^{\mathrm{c}}$ & 26.34 & $1,941,489$ & $1,941,489$ & $1,941,489$ & $1,941,489$ \\
\hline $\begin{array}{l}\text { Tipping fees for green waste } \\
\text { dropped off at collection pts. }\end{array}$ & 120.0 & $8,844,138$ & $6,343,920$ & $8,844,138$ & - \\
\hline \multirow[t]{2}{*}{$\begin{array}{l}\text { Tipping fees for third-party } \\
\text { management of green waste }\end{array}$} & 20.0 & - & 416,703 & - & - \\
\hline & Unit & $\begin{array}{c}\text { LCC } \\
\text { (life cycle) } \\
\end{array}$ & $\begin{array}{c}\text { LCC } \\
\text { (investor) } \\
\end{array}$ & SLCA & $\begin{array}{l}\text { Abatement } \\
\text { costs }\end{array}$ \\
\hline \multirow{4}{*}{$\begin{array}{l}\text { HTC-coal production costs } \\
\text { (at a } 92 \% \text { DM content of HTC } \\
\text { coal; net of tipping fees for } \\
\text { third-party management of } \\
\text { green waste) })^{j}\end{array}$} & $€ / \mathrm{a}$ & - & $4,462,321$ & - & - \\
\hline & $\begin{array}{l}€ / \mathrm{Mg} \mathrm{FM} \\
\text { input }\end{array}$ & - & 60.5 & - & - \\
\hline & $\begin{array}{l}€ / \mathrm{Mg} \mathrm{HTC} \\
\text { coal }\end{array}$ & - & 268.1 & - & - \\
\hline & $€ / \mathrm{MWh}$ & - & 52.5 & - & - \\
\hline $\mathrm{NPV}^{\mathrm{k}}$ & $€$ & $47,423,341$ & $24,466,114$ & $27,672,367$ & $-66,811,690$ \\
\hline Annuity $_{H T C}{ }^{1}$ & $€ / \mathrm{a}$ & - & - & - & $6,063,588$ \\
\hline
\end{tabular}

Sources:

a) $€ 15,000,000$ for the HTC plant (Table 13) and $€ 16,958,000$ for the biomass CHP plant (Table 15).

b) Table 5, last row.

c) Column 1: Table 13. Columns 2 to 5: Multiplying the value from column 1 by 73,701 Mg FM/a (Table 1).

d) Table 14 .

e) Table 15 .

f) $70 € / \mathrm{Mg} \mathrm{CO}_{2} \mathrm{e}$ (Krewitt and Schlomann 2006: 1) multiplied by the GHG emissions of the urban HTC scenario of about $3,844 \mathrm{Mg} \mathrm{CO}_{2} \mathrm{e} / \mathrm{a}$ (Table 12). 
g) Column 1: Table 13. Columns 2 to 3 [columns 4 to 5]: Multiplying the $28.40 € / \mathrm{Mg}$ FM input [7.73 €/Mg FM input] from column 1 by 73,701 Mg FM/a (Table 1).

h) Column 1: Table 13. Columns 2 and 4 [column 3]: Multiplying the value from column 1 by 73,701 Mg FM/a [52,866 Mg FM/a of BSR's own green-waste collections] (Table 1).

i) Column 1: Table 13. Column 3: Multiplying the value from column 1 by 20,835 Mg FM/a of leaves and grass cuttings from parks departments (Table 1).

j) Value in $€ /$ a: Sum of all transportation costs, preparation, baling, and storage costs, consumption-related costs (without HTC-coal combustion), and operation-related costs (without HTC-coal combustion), minus revenues from tipping fees for third-party management of green waste. The value in $€ / \mathrm{a}$ is transformed into $€ / \mathrm{Mg} F M$ input [€/Mg HTC coal] by dividing it by $73,701 \mathrm{Mg} \mathrm{FM} / \mathrm{a}$ (Table 1) [16,641 Mg HTC coal/a (Section 3.1.1)]. The value in $€ / \mathrm{Mg}$ FM input is further transformed into $€ / M W h$ by dividing it by the usable energy from HTC coal (Table 3 ) and multiplying it by 1,000 .

k) Own calculation, based on equations (1), (3), (4), and (7), respectively.

1) Own calculation, based on equation (6).

Notes: Values rounded. - Not applicable. 
Table 18: Rural-Urban HTC Scenario

\begin{tabular}{|c|c|c|c|c|c|}
\hline & Unit & $\begin{array}{c}\mathrm{LCC} \\
\text { (life cycle) } \\
\end{array}$ & $\begin{array}{c}\mathrm{LCC} \\
\text { (investor) } \\
\end{array}$ & $\overline{\text { SLCA }}$ & $\begin{array}{c}\text { Abatement } \\
\text { costs } \\
\end{array}$ \\
\hline Capital-related costs: $C_{\theta^{a}}$ & $€$ & \multicolumn{4}{|c|}{$15,000,000$} \\
\hline & Value & $\overline{C F_{t, L C C}}$ & $\overline{C F_{t, \text { investor }}}$ & $\begin{array}{c}C F_{t, L C C+}+ \\
C F_{t, S L C A} \\
\end{array}$ & $\overline{C F_{t, L C C}^{\prime}}$ \\
\hline & $\begin{array}{l}€ / \mathrm{Mg} F M \\
\text { input }\end{array}$ & \multicolumn{4}{|c|}{$€ / \mathrm{a}$} \\
\hline & (1) & (2) & (3) & (4) & (5) \\
\hline Transportation costs & - & $1,282,762$ & $1,282,762$ & $1,282,762$ & $1,282,762$ \\
\hline Biomass $^{\mathrm{b}}$ & - & $1,282,762$ & $1,282,762$ & $1,282,762$ & $1,282,762$ \\
\hline $\begin{array}{l}\text { Preparation, baling, and } \\
\text { storage costs }\end{array}$ & - & $1,933,542$ & $1,933,542$ & $1,933,542$ & $1,933,542$ \\
\hline $\begin{array}{l}\text { Biomass preparation } \\
\text { (including electricity) }^{\mathrm{c}}\end{array}$ & 15.0 & $1,134,309$ & $1,134,309$ & $1,134,309$ & $1,134,309$ \\
\hline Residue disposal $^{\mathrm{c}}$ & 4.9 & 370,541 & 370,541 & 370,541 & 370,541 \\
\hline Baling and storage $\left(C_{\text {stor }}\right)^{\mathrm{d}}$ & - & 428,692 & 428,692 & 428,692 & 428,692 \\
\hline Consumption-related costs & - & 427,293 & 427,293 & 427,293 & 427,293 \\
\hline $\begin{array}{l}\text { Electricity (for HTC-coal } \\
\text { drying) }\end{array}$ & 1.58 & 119,670 & 119,670 & 119,670 & 119,670 \\
\hline Natural gas ${ }^{\mathrm{c}}$ & 1.00 & 75,557 & 75,557 & 75,557 & 75,557 \\
\hline Diesel fuel $^{\mathrm{c}}$ & 0.34 & 25,562 & 25,562 & 25,562 & 25,562 \\
\hline Fresh water ${ }^{\mathrm{c}}$ & 0.05 & 3,906 & 3,906 & 3,906 & 3,906 \\
\hline Wastewater treatment ${ }^{\mathrm{c}}$ & 1.5 & 113,431 & 113,431 & 113,431 & 113,431 \\
\hline HTC-coal combustion $^{\text {e }}$ & 1.18 & 89,168 & 89,168 & 89,168 & 89,168 \\
\hline Operation-related costs & - & 697,417 & 697,417 & 697,417 & 697,417 \\
\hline Personnel $^{\mathrm{c}}$ & 2.8 & 211,738 & 211,738 & 211,738 & 211,738 \\
\hline Service and maintenance ${ }^{c}$ & 2.8 & 211,738 & 211,738 & 211,738 & 211,738 \\
\hline HTC-coal combustion $^{\mathrm{e}}$ & 3.62 & 273,941 & 273,941 & 273,941 & 273,941 \\
\hline Damage costs ${ }^{\mathrm{f}}$ & - & - & - & 271,456 & - \\
\hline Revenues & - & $11,104,011$ & 3,541,952 & 11,104,011 & - \\
\hline Sales of electricity ${ }^{\mathrm{c}}$ & 11.84 & 895,556 & 895,556 & 895,556 & - \\
\hline Sales of heat ${ }^{\mathrm{c}}$ & 15.00 & $1,133,984$ & $1,133,984$ & $1,133,984$ & - \\
\hline $\begin{array}{l}\text { Tipping fees for green waste } \\
\text { dropped off at collection pts. }\end{array}$ & 120.0 & $9,074,471$ & - & $9,074,471$ & - \\
\hline \multirow[t]{2}{*}{$\begin{array}{l}\text { Tipping fees for third-party } \\
\text { management of green waste }\end{array}$} & 20.0 & - & $1,512,412$ & - & - \\
\hline & Unit & $\begin{array}{c}\text { LCC } \\
\text { (life cycle) }\end{array}$ & $\begin{array}{c}\mathrm{LCC} \\
\text { (investor) }\end{array}$ & $\overline{\text { SLCA }}$ & $\begin{array}{l}\text { Abatement } \\
\text { costs }\end{array}$ \\
\hline \multirow{4}{*}{$\begin{array}{l}\text { HTC-coal production costs } \\
\text { (at a 92\% DM content of HTC } \\
\text { coal; net of tipping fees for } \\
\text { third-party management of } \\
\text { green waste) } \text { g }^{\mathrm{g}}\end{array}$} & $€ / \mathrm{a}$ & - & $2,465,493$ & - & - \\
\hline & $\begin{array}{l}€ / \mathrm{Mg} \mathrm{FM} \\
\text { input }\end{array}$ & - & 32.6 & - & - \\
\hline & $\begin{array}{l}€ / \mathrm{Mg} \mathrm{HTC} \\
\text { coal }\end{array}$ & - & 141.3 & - & \\
\hline & $€ / \mathrm{MWh}$ & - & 35.3 & - & - \\
\hline $\mathrm{NPV}^{\mathrm{h}}$ & $€$ & $59,518,127$ & $-23,804,480$ & $56,527,090$ & $-62,831,500$ \\
\hline Annuity $_{H T C}{ }^{\mathrm{i}}$ & $€ / a$ & - & - & - & $5,702,360$ \\
\hline
\end{tabular}

\section{Sources:}

a) $€ 15,000,000$ for the HTC plant (Table 13).

b) Table 6, last row.

c) Column 1: Table 13. Columns 2 to 5: Multiplying the value from column 1 by 75,621 Mg FM/a (Table 1).

d) Table 14.

e) Column 1: Multiplying the respective value of $1.28 € / \mathrm{MWh}$ of consumption-related costs $(3.93 € / \mathrm{MWh}$ of operation-related costs) at the Vattenfall Reuter West CHP plant (Table 16) by the usable energy from HTC coal (Table 3) and dividing it by 1,000. Columns 2 to 5: Multiplying the value from column 1 by $75,621 \mathrm{Mg}$ FM/a (Table 1). 
f) $70 € / \mathrm{Mg} \mathrm{CO}_{2} \mathrm{e}$ (Krewitt and Schlomann 2006: 1) multiplied by the GHG emissions of the rural-urban HTC scenario of about 3,878 $\mathrm{Mg} \mathrm{CO}_{2} \mathrm{e} / \mathrm{a}$ (Table 12).

g) Value in $€ / a$ : Sum of all transportation costs, preparation, baling, and storage costs, consumption-related costs (without HTC-coal combustion), and operation-related costs (without HTC-coal combustion), minus revenues from tipping fees for third-party management of green waste. The value in $€ / \mathrm{a}$ is transformed into $€ / \mathrm{Mg} F M$ input [€/Mg HTC coal] by dividing it by $75,621 \mathrm{Mg}$ FM/a (Table 1) [17,446 Mg HTC coal/a (Section 3.1.1)]. The value in $€ / \mathrm{Mg} F M$ input is further transformed into $€ / M W h$ by dividing it by the usable energy from HTC coal (Table 3) and multiplying it by 1,000.

h) Own calculation, based on equations (1), (3), (4), and (7), respectively.

i) Own calculation, based on equation (6).

Notes: Values rounded. - Not applicable. 
Table 19: Rural HTC Scenario

\begin{tabular}{|c|c|c|c|c|c|}
\hline & Unit & $\begin{array}{c}\text { LCC } \\
\text { (life cycle) }\end{array}$ & $\begin{array}{c}\text { LCC } \\
\text { (investor) }\end{array}$ & SLCA & $\begin{array}{l}\text { Abatement } \\
\text { costs }\end{array}$ \\
\hline Capital-related costs: $C_{\theta^{a}}$ & $€$ & \multicolumn{4}{|c|}{$15,000,000$} \\
\hline & Value & $C F_{t, L C C}$ & $C F_{t, \text { investor }}$ & $\begin{array}{c}C F_{t, L C C}+ \\
C F_{t, S L C A}\end{array}$ & $C F_{t, L C C}^{\prime}$ \\
\hline & $\begin{array}{l}€ / \mathrm{Mg} \mathrm{FM} \\
\text { input }\end{array}$ & \multicolumn{4}{|c|}{$€ / \mathrm{a}$} \\
\hline & (1) & (2) & (3) & (4) & (5) \\
\hline Transportation costs & - & $1,775,822$ & $1,550,610$ & $1,775,822$ & $1,775,822$ \\
\hline Biomass $^{\mathrm{b}}$ & - & $1,550,610$ & $1,550,610$ & $1,550,610$ & $1,550,610$ \\
\hline HTC coal $^{\text {b }}$ & - & 225,212 & - & 225,212 & 225,212 \\
\hline $\begin{array}{l}\text { Preparation, baling, and } \\
\text { storage costs }\end{array}$ & - & $2,047,775$ & $2,047,775$ & $2,047,775$ & $2,047,775$ \\
\hline $\begin{array}{l}\text { Biomass preparation } \\
\text { (including electricity) }^{\mathrm{c}}\end{array}$ & 15.0 & $1,220,414$ & $1,220,414$ & $1,220,414$ & $1,220,414$ \\
\hline Residue disposal $^{\mathrm{c}}$ & 4.9 & 398,669 & 398,669 & 398,669 & 398,669 \\
\hline Baling and storage $\left(C_{\text {stor }}\right)^{\mathrm{d}}$ & - & 428,692 & 428,692 & 428,692 & 428,692 \\
\hline Consumption-related costs & - & 677,200 & 575,734 & 677,200 & 677,200 \\
\hline $\begin{array}{l}\text { Electricity (for HTC-coal } \\
\text { drying) }^{c}\end{array}$ & 4.28 & 347,897 & 347,897 & 347,897 & 347,897 \\
\hline Natural gas ${ }^{\mathrm{c}}$ & 0.93 & 75,557 & 75,557 & 75,557 & 75,557 \\
\hline Diesel fuel $^{\mathrm{c}}$ & 0.34 & 27,502 & 27,502 & 27,502 & 27,502 \\
\hline Fresh water ${ }^{\mathrm{c}}$ & 0.03 & 2,736 & 2,736 & 2,736 & 2,736 \\
\hline Wastewater treatment ${ }^{\mathrm{c}}$ & 1.5 & 122,041 & 122,041 & 122,041 & 122,041 \\
\hline HTC-coal combustion $^{\mathrm{e}}$ & 1.25 & 101,466 & - & 101,466 & 101,466 \\
\hline Operation-related costs & - & 767,345 & 455,621 & 767,345 & 767,345 \\
\hline Personnel $^{\mathrm{c}}$ & 2.8 & 227,811 & 227,811 & 227,811 & 227,811 \\
\hline Service and maintenance ${ }^{c}$ & 2.8 & 227,811 & 227,811 & 227,811 & 227,811 \\
\hline HTC-coal combustion $^{\mathrm{e}}$ & 3.83 & 311,724 & - & 311,724 & 311,724 \\
\hline Damage costs ${ }^{\mathrm{f}}$ & - & - & - & 316,222 & - \\
\hline Revenues & 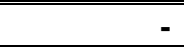 & $12,072,771$ & $\mathbf{3 , 1 3 3 , 5 7 0}$ & $12,072,771$ & - \\
\hline Sales of electricity ${ }^{\mathrm{c}}$ & 12.53 & $1,019,073$ & - & $1,019,073$ & - \\
\hline Sales of heat ${ }^{\mathrm{c}}$ & 15.86 & $1,290,385$ & - & $1,290,385$ & - \\
\hline Sales of HTC coal ${ }^{g}$ & 18.51 & - & $1,506,351$ & - & - \\
\hline $\begin{array}{l}\text { Tipping fees for green waste } \\
\text { dropped off at collection pts. }\end{array}$ & 120.0 & $9,763,314$ & - & $9,763,314$ & - \\
\hline \multirow[t]{2}{*}{$\begin{array}{l}\text { Tipping fees for third-party } \\
\text { management of green waste }\end{array}$} & 20.0 & - & $1,627,219$ & - & - \\
\hline & Unit & $\begin{array}{c}\text { LCC } \\
\text { (life cycle) }\end{array}$ & $\begin{array}{c}\mathrm{LCC} \\
\text { (investor) }\end{array}$ & $\overline{\text { SLCA }}$ & $\begin{array}{c}\text { Abatement } \\
\text { costs }\end{array}$ \\
\hline \multirow{4}{*}{$\begin{array}{l}\text { HTC-coal production costs } \\
\text { (at a } 92 \% \text { DM content of HTC } \\
\text { coal; net of tipping fees for } \\
\text { third-party management of } \\
\text { green waste) }\end{array}$} & $€ / \mathrm{a}$ & - & $3,002,521$ & - & - \\
\hline & $\begin{array}{l}€ / \mathrm{Mg} \mathrm{FM} \\
\text { input }\end{array}$ & - & 36.9 & - & - \\
\hline & $\begin{array}{c}€ / \mathrm{Mg} \mathrm{HTC} \\
\text { coal }\end{array}$ & - & 151.2 & - & - \\
\hline & $€ / \mathrm{MWh}$ & - & 37.8 & - & - \\
\hline $\mathrm{NPV}^{\mathrm{i}}$ & $€$ & $59,976,851$ & $-31,485,556$ & $56,492,561$ & $-73,047,066$ \\
\hline Annuity $_{H T C}{ }^{\mathrm{j}}$ & $€ / \mathrm{a}$ & - & - & - & $6,629,488$ \\
\hline
\end{tabular}

Sources:

a) $€ 15,000,000$ for the HTC plant (Table 13).

b) Table 7 , sum of the respective $C_{\text {trans, } r \text {. }}$

c) Column 1: Table 13. Columns 2 to 5: Multiplying the value from column 1 by 81,361 Mg FM/a (Table 1).

d) Table 14 .

e) Column 1: Multiplying the respective value of $1.28 € / \mathrm{MWh}$ of consumption-related costs $(3.93 € / \mathrm{MWh}$ of operation-related costs) at the Vattenfall Reuter West CHP plant (Table 16) by the usable energy from HTC 
coal (Table 3) and dividing it by 1,000. Columns 2 to 5: Multiplying the value from column 1 by $81,361 \mathrm{Mg}$ FM/a (Table 1).

f) $70 € / \mathrm{Mg} \mathrm{CO}_{2} \mathrm{e}$ (Krewitt and Schlomann 2006: 1) multiplied by the GHG emissions of the rural HTC scenario of about 4,517 $\mathrm{Mg} \mathrm{CO}_{2} \mathrm{e} / \mathrm{a}$ (Table 12).

g) Column 1: Multiplying 21.81 €/MWh (Section 3.2.2), divided by 1,000, by the usable energy from rural HTC coal (Table 3), and subtracting the HTC-coal transportation costs of 225,212 €/Mg FM input (Table 7) divided by $81,361 \mathrm{Mg} \mathrm{FM} / \mathrm{a}$ (Table 1). Column 3: Multiplying the value from column 1 by 81,361 Mg FM/a (Table 1).

h) Value in $€ / a$ : Sum of transportation costs, preparation, baling, and storage costs, consumption-related costs, and operation-related costs, minus revenues from tipping fees for third-party management of green waste. The value in $€ / \mathrm{a}$ is transformed into $€ / \mathrm{Mg}$ FM input [ $€ / \mathrm{Mg}$ HTC coal] by dividing it by $81,361 \mathrm{Mg}$ FM/a (Table 1 ) [19,852 Mg HTC coal/a (Section 3.1.1)]. The value in $€ / M g$ FM input is further transformed into $€ / M W h$ by dividing it by the usable energy from HTC coal (Table 3) and multiplying it by 1,000.

i) Own calculation, based on equations (1), (3), (4), and (7), respectively.

j) Own calculation, based on equation (6).

Notes: Values rounded. - Not applicable. 
Table 20: Urban Reference Scenario

\begin{tabular}{|c|c|c|c|c|c|}
\hline & $\begin{array}{l}\text { Value } \\
\text { Valu }\end{array}$ & $\begin{array}{c}\text { LCC } \\
\text { (life cycle) }\end{array}$ & $\begin{array}{c}\mathrm{LCC} \\
\text { (investor) } \\
\end{array}$ & $\overline{\text { SLCA }}$ & $\begin{array}{c}\text { Abatement } \\
\text { costs }\end{array}$ \\
\hline & & $C F_{t, L C C}$ & $C F_{t, \text { investor }}$ & $\begin{array}{c}C \boldsymbol{F}_{t, L C C}+ \\
C \boldsymbol{F}_{t, S L C A}\end{array}$ & $C F_{t, L C C}^{\prime}$ \\
\hline & $\begin{array}{l}€ / \mathrm{Mg} \mathrm{FM} \\
\text { input }\end{array}$ & \multicolumn{4}{|c|}{$€ / \mathrm{a}$} \\
\hline & (1) & (2) & (3) & (4) & (5) \\
\hline Transportation costs & - & $1,531,054$ & 997,116 & $1,531,054$ & $\mathbf{1 , 5 3 1 , 0 5 4}$ \\
\hline Biomass $^{\mathrm{a}}$ & - & $1,322,254$ & 997,116 & $1,322,254$ & $1,322,254$ \\
\hline Compost $^{\mathrm{a}}$ & - & 208,800 & - & 208,800 & 208,800 \\
\hline $\begin{array}{l}\text { Capital-related costs for } \\
\text { composting b }\end{array}$ & 9.00 & 663,310 & - & 663,310 & 663,310 \\
\hline Consumption-related costs & - & $2,133,642$ & $\mathbf{1 , 0 5 7 , 3 2 0}$ & $\mathbf{1 , 8 3 8 , 2 8 6}$ & 1,838,286 \\
\hline Composting $^{\mathrm{c}}$ & - & 170,250 & - & 170,250 & 170,250 \\
\hline $\begin{array}{l}\text { Hard-coal combustion [for } \\
\text { SLCA and abatement costs] }\end{array}$ & $\begin{array}{r}26.6 \\
{[22.6]}\end{array}$ & $1,963,393$ & - & $1,668,037$ & $1,668,037$ \\
\hline Tipping fees for composting & 20.0 & - & $1,057,320$ & - & - \\
\hline Operation-related costs & - & 974,356 & - & 974,356 & 974,356 \\
\hline Composting $^{\mathrm{f}}$ & - & 640,463 & - & 640,463 & 640,463 \\
\hline Hard-coal combustion ${ }^{g}$ & 4.5 & 333,893 & - & 333,893 & 333,893 \\
\hline Damage costs ${ }^{\mathrm{h}}$ & - & - & - & $1,825,213$ & - \\
\hline Revenues & 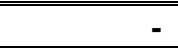 & $111,403,547$ & 6,343,920 & $11,403,547$ & $2,559,409$ \\
\hline Sales of compost ${ }^{\mathrm{i}}$ & 1.16 & 85,705 & - & 85,705 & 85,705 \\
\hline Sales of electricity ${ }^{j}$ & 14.81 & $1,091,548$ & - & $1,091,548$ & $1,091,548$ \\
\hline Sales of heat ${ }^{j}$ & 18.75 & $1,382,155$ & - & $1,382,155$ & $1,382,155$ \\
\hline \multirow[t]{2}{*}{$\begin{array}{l}\text { Tipping fees for green waste } \\
\text { dropped off at collection pts. }\end{array}$} & 120.0 & $8,844,138$ & $6,343,920$ & $8,844,138$ & - \\
\hline & Unit & $\begin{array}{c}\text { LCC } \\
\text { (life cycle) }\end{array}$ & $\begin{array}{c}\mathrm{LCC} \\
\text { (investor) }\end{array}$ & SLCA & $\begin{array}{l}\text { Abatement } \\
\text { costs }\end{array}$ \\
\hline $\mathrm{NPV}^{\mathrm{l}}$ & $\bar{€}$ & $67,225,940$ & $47,263,714$ & $50,369,198$ & $-26,968,880$ \\
\hline Annuity $_{\text {Reference }}{ }^{\mathrm{m}}$ & $€ / \mathrm{a}$ & - & - & - & $2,447,598$ \\
\hline
\end{tabular}

Sources:

a) Table 8. While the biomass transportation costs in columns 2, 4, and 5 refer to the sum of the respective $C_{\text {trans, } r}$ for the biomass managed by $B S R$ and the parks departments, column 3 contains only the biomass transportation costs for the $B S R$ leaves and grass cuttings.

b) Column 1: van Haaren et al. (2010: 2654). Columns 2 to 5: Multiplying the value from column 1 by 73,701 $\mathrm{Mg} \mathrm{FM/a} \mathrm{(Table} \mathrm{1).}$

c) $21 \%$ of $810,713 € / \mathrm{a}$ (Section 3.2.1).

d) Column 1: $23.08 € / \mathrm{MWh}[19.61 € / \mathrm{MWh}$ (Table 16) multiplied by the usable energy from urban HTC coal (Table 3) and divided by 1,000. Column 2 [columns 4 and 5]: Multiplying the $26.6 € / \mathrm{Mg}$ FM input $[22.6 € / \mathrm{Mg}$ FM input] from column 1 by 73,701 Mg FM/a (Table 1).

e) Column 1: SunCoal (2012: 2); Table 13, i.e. the same as for third-party management of green waste in the urban HTC scenario. Column 3: Multiplying the value from column 1 by $52,866 \mathrm{Mg} \mathrm{FM} / \mathrm{a}$ of $B S R$ 's own greenwaste collections (Table 1).

f) $79 \%$ of $810,713 € / \mathrm{a}($ Section 3.2.1).

g) Column 1: $3.93 € / \mathrm{MWh}$ (Table 16) multiplied by the usable energy from urban HTC coal (Table 3 ) and divided by 1,000. Columns 2 to 5: Multiplying the value from column 1 by 73,701 Mg FM/a (Table 1).

h) $70 € / \mathrm{Mg} \mathrm{CO}_{2} \mathrm{e}$ (Krewitt and Schlomann 2006: 1) multiplied by the GHG emissions of the urban reference scenario of about $26,074 \mathrm{Mg} \mathrm{CO}_{2} \mathrm{e} / \mathrm{a}$ (Table 12).

i) Column 1: $11.63 € / \mathrm{Mg}$ compost (Bundesgütegemeinschaft Kompost 2017: 6) multiplied by the respective compost share of $40 \%$ for leaves and $18 \%$ for grass cuttings (Table 2) and weighted by the respective share of leaves $(74.4 \%)$ and grass cuttings $(25.6 \%)$ in the urban biomass (Table 1), minus transportation costs for compost of $208,800 € / \mathrm{a}$ (Table 8 ) divided by 73,701 Mg FM/a (Table 1). Columns 2 to 5: Multiplying the value from column 1 by 73,701 Mg FM/a (Table 1).

j) Column 1: Table 16. Columns 2 to 5: Multiplying the value from column 1 by 73,701 Mg FM/a (Table 1). 
k) Column 1: Table 13, i.e. the same as in the urban HTC scenario. Columns 2 and 4 [column 3]: Multiplying the value from column 1 by 73,701 Mg FM/a [52,866 Mg FM/a of BSR's own green-waste collections] (Table 1).

1) Own calculation, based on equations (1), (3), (4), and (7), respectively.

m) Own calculation, based on equation (6).

Notes: Values rounded. - Not applicable. 
Table 21: Rural-Urban Reference Scenario

\begin{tabular}{|c|c|c|c|c|c|}
\hline & Value & $\begin{array}{c}\text { LCC } \\
\text { (life cycle) }\end{array}$ & $\begin{array}{c}\text { LCC } \\
\text { (investor) }\end{array}$ & SLCA & $\begin{array}{l}\text { Abatement } \\
\text { costs }\end{array}$ \\
\hline & & $C F_{t, L C C}$ & $C F_{t, \text { investor }}$ & $\begin{array}{c}C \boldsymbol{F}_{t, L C C}+ \\
C \boldsymbol{F}_{t, S L C A}\end{array}$ & $C F_{t, L C C}^{\prime}$ \\
\hline & $\begin{array}{l}€ / \mathrm{Mg} \mathrm{FM} \\
\text { input }\end{array}$ & \multicolumn{4}{|c|}{$€ / \mathrm{a}$} \\
\hline & (1) & (2) & (3) & (4) & (5) \\
\hline Transportation costs & - & 930,140 & - & 930,140 & 930,140 \\
\hline Biomass $^{\mathrm{a}}$ & - & 800,074 & - & 800,074 & 800,074 \\
\hline Compost $^{\mathrm{a}}$ & - & 130,066 & - & 130,066 & 130,066 \\
\hline $\begin{array}{l}\text { Capital-related costs for } \\
\text { composting }\end{array}$ & 9.00 & 680,585 & - & 680,585 & 680,585 \\
\hline Consumption-related costs & - & $\mathbf{1 , 7 8 5 , 5 4 1}$ & $\mathbf{1 , 6 1 0 , 8 5 7}$ & $1,543,218$ & $1,543,218$ \\
\hline Composting $^{\mathrm{c}}$ & - & 174,684 & - & 174,684 & 174,684 \\
\hline $\begin{array}{l}\text { Hard-coal combustion [for } \\
\text { SLCA and abatement costs] }\end{array}$ & $\begin{array}{r}21.3 \\
{[18.1]}\end{array}$ & $1,610,857$ & $1,610,857$ & $1,368,534$ & $1,368,534$ \\
\hline Operation-related costs & - & 931,084 & 273,941 & 931,084 & 931,084 \\
\hline Composting ${ }^{\mathrm{e}}$ & - & 657,143 & - & 657,143 & 657,143 \\
\hline Hard-coal combustion ${ }^{\mathrm{f}}$ & 3.6 & 273,941 & 273,941 & 273,941 & 273,941 \\
\hline Damage costs ${ }^{g}$ & - & - & - & $1,848,694$ & - \\
\hline Revenues & 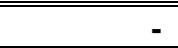 & $111,157,399$ & $2,029,540$ & $11,157,399$ & $\overline{53,388}$ \\
\hline Sales of compost ${ }^{\mathrm{h}}$ & 0.71 & 53,388 & - & 53,388 & 53,388 \\
\hline Sales of electricity ${ }^{i}$ & 11.84 & 895,556 & 895,556 & 895,556 & - \\
\hline Sales of heat ${ }^{i}$ & 15.00 & $1,133,984$ & $1,133,984$ & $1,133,984$ & - \\
\hline \multirow[t]{2}{*}{$\begin{array}{l}\text { Tipping fees for green waste } \\
\text { dropped off at collection pts. }{ }^{j}\end{array}$} & 120.0 & $9,074,471$ & - & $9,074,471$ & - \\
\hline & Unit & $\begin{array}{c}\mathrm{LCC} \\
\text { (life cycle) }\end{array}$ & $\begin{array}{c}\mathrm{LCC} \\
\text { (investor) }\end{array}$ & $\overline{\text { SLCA }}$ & $\begin{array}{l}\text { Abatement } \\
\text { costs }\end{array}$ \\
\hline $\mathrm{NPV}^{\mathrm{k}}$ & $\bar{€}$ & $75,256,930$ & $1,594,827$ & $57,557,124$ & $-44,422,653$ \\
\hline Annuity $_{\text {Reference }}{ }^{1}$ & $€ / \mathrm{a}$ & - & - & - & $4,031,640$ \\
\hline
\end{tabular}

Sources:

a) Table 9 .

b) Column 1: van Haaren et al. (2010: 2654). Columns 2 to 5: Multiplying the value from column 1 by 75,621 $\mathrm{Mg} \mathrm{FM/a} \mathrm{(Table} \mathrm{1).}$

c) $21 \%$ of $831,827 € / \mathrm{a}($ Section 3.2 .1$)$.

d) Column 1: $23.08 € / \mathrm{MWh}$ [19.61 €/MWh] (Table 16) multiplied by the usable energy from rural-urban HTC coal (Table 3) and divided by 1,000. Columns 2 and 3 [columns 4 and 5]: Multiplying the 21.3€/Mg FM input [18.1 €/Mg FM input] from column 1 by 75,621 Mg FM/a (Table 1).

e) $79 \%$ of $831,827 € / \mathrm{a}($ Section 3.2.1).

f) Column 1: $3.93 € / \mathrm{MWh}$ (Table 16) multiplied by the usable energy from rural-urban HTC coal (Table 3 ) and divided by 1,000 . Columns 2 to 5: Multiplying the value from column 1 by $75,621 \mathrm{Mg} \mathrm{FM/a} \mathrm{(Table} \mathrm{1).}$

g) $70 € / \mathrm{Mg} \mathrm{CO}_{2} \mathrm{e}$ (Krewitt and Schlomann 2006: 1) multiplied by the GHG emissions of the rural-urban reference scenario of about $26,410 \mathrm{Mg} \mathrm{CO}_{2} \mathrm{e} / \mathrm{a}$ (Table 12).

h) Column 1: $11.63 € / \mathrm{Mg}$ compost (Bundesgütegemeinschaft Kompost 2017: 6) multiplied by the respective compost share of $40 \%$ for leaves and $18 \%$ for grass cuttings (Table 2) and weighted by the respective share of leaves $(13.0 \%)$ and grass cuttings $(87.0 \%)$ in the rural-urban biomass (Table 1), minus transportation costs for compost of 130,066 €/a (Table 9) divided by 75,621 Mg FM/a (Table 1). Columns 2 to 5: Multiplying the value from column 1 by 75,621 Mg FM/a (Table 1).

i) Column 1: Table 16. Columns 2 to 5: Multiplying the value from column 1 by 75,621 Mg FM/a (Table 1).

j) Column 1: Table 13, i.e. the same as in the rural-urban HTC scenario. Columns 2 and 4: Multiplying the value from column 1 by 75,621 Mg FM/a (Table 1).

k) Own calculation, based on equations (1), (3), (4), and (7), respectively.

1) Own calculation, based on equation (6).

Notes: Values rounded. - Not applicable. 
Table 22: Rural Reference Scenario

\begin{tabular}{|c|c|c|c|c|c|}
\hline & Value & $\begin{array}{c}\text { LCC } \\
\text { (life cycle) } \\
\end{array}$ & $\begin{array}{c}\mathrm{LCC} \\
\text { (investor) } \\
\end{array}$ & SLCA & $\begin{array}{c}\text { Abatement } \\
\text { costs }\end{array}$ \\
\hline & & $C F_{t, L C C}$ & $C F_{t, \text { investor }}$ & $\begin{array}{c}C F_{t, L C C}+ \\
C F_{t, S L C A}\end{array}$ & $C F_{t, L C C}^{\prime}$ \\
\hline & $\begin{array}{c}€ / \mathrm{Mg} \text { FM } \\
\text { input }\end{array}$ & \multicolumn{4}{|c|}{$€ / \mathrm{a}$} \\
\hline & (1) & (2) & (3) & (4) & (5) \\
\hline Transportation costs & - & $1,245,803$ & - & $1,245,803$ & $1,245,803$ \\
\hline Biomass $^{\mathrm{a}}$ & - & $1,125,048$ & - & $1,125,048$ & $1,125,048$ \\
\hline Compost $^{\mathrm{a}}$ & - & 120,755 & - & 120,755 & 120,755 \\
\hline $\begin{array}{l}\text { Capital-related costs for } \\
\text { composting }\end{array}$ & 9.00 & 732,249 & - & 732,249 & 732,249 \\
\hline Consumption-related costs & - & $2,020,974$ & - & $1,745,228$ & $1,745,228$ \\
\hline Composting $^{\mathrm{c}}$ & - & 187,944 & - & 187,944 & 187,944 \\
\hline $\begin{array}{l}\text { Hard-coal combustion [for } \\
\text { SLCA and abatement costs] }\end{array}$ & $\begin{array}{r}22.5 \\
{[19.1]} \\
\end{array}$ & $1,833,030$ & - & $1,557,285$ & $1,557,285$ \\
\hline Operation-related costs & - & $1,018,751$ & - & $1,018,751$ & $1,018,751$ \\
\hline Composting $^{\mathrm{e}}$ & - & 707,027 & - & 707,027 & 707,027 \\
\hline Hard-coal combustion $^{\mathrm{f}}$ & 3.8 & 311,724 & - & 311,724 & 311,724 \\
\hline Damage costs ${ }^{g}$ & - & - & - & $2,118,641$ & - \\
\hline Revenues & 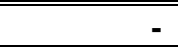 & $12,122,337$ & - & $12,122,337$ & 49,566 \\
\hline Sales of compost ${ }^{\mathrm{h}}$ & 0.61 & 49,566 & - & 49,566 & 49,566 \\
\hline Sales of electricity ${ }^{\mathrm{i}}$ & 12.53 & $1,019,073$ & - & $1,019,073$ & - \\
\hline Sales of heat ${ }^{\mathrm{i}}$ & 15.86 & $1,290,385$ & - & $1,290,385$ & - \\
\hline \multirow[t]{2}{*}{$\begin{array}{l}\text { Tipping fees for green waste } \\
\text { dropped off at collection pts. }\end{array}$} & 120.0 & $9,763,314$ & - & $9,763,314$ & - \\
\hline & Unit & $\begin{array}{c}\text { LCC } \\
\text { (life cycle) } \\
\end{array}$ & $\begin{array}{c}\text { LCC } \\
\text { (investor) } \\
\end{array}$ & SLCA & $\begin{array}{c}\text { Abatement } \\
\text { costs }\end{array}$ \\
\hline $\mathrm{NPV}^{\mathrm{k}}$ & $€$ & $78,281,664$ & 0 & $57,975,700$ & $-51,703,952$ \\
\hline Annuity $_{\text {Reference }}{ }^{1}$ & $€ / \mathrm{a}$ & - & - & - & $4,692,464$ \\
\hline
\end{tabular}

Sources:

a) Table 10 .

b) Column 1: van Haaren et al. (2010: 2654). Columns 2 to 5: Multiplying the value from column 1 by 81,361 $\mathrm{Mg} \mathrm{FM/a} \mathrm{(Table} \mathrm{1).}$

c) $21 \%$ of $894,970 € / \mathrm{a}($ Section 3.2.1).

d) Column 1: $23.08 € / \mathrm{MWh}[19.61 € / \mathrm{MWh}$ (Table 16) multiplied by the usable energy from rural HTC coal (Table 3) and divided by 1,000. Column 2 [columns 4 and 5]: Multiplying the $22.5 € / \mathrm{Mg} \mathrm{FM}$ input [19.1 €/Mg FM input] from column 1 by $81,361 \mathrm{Mg}$ FM/a (Table 1).

e) $79 \%$ of $894,970 € /$ a (Section 3.2.1).

f) Column 1: $3.93 € / \mathrm{MWh}$ (Table 16) multiplied by the usable energy from rural HTC coal (Table 3) and divided by 1,000. Columns 2 to 5: Multiplying the value from column 1 by 81,361 Mg FM/a (Table 1).

g) $70 € / \mathrm{Mg} \mathrm{CO}_{2} \mathrm{e}$ (Krewitt and Schlomann 2006: 1) multiplied by the GHG emissions of the rural reference scenario of about $30,266 \mathrm{Mg} \mathrm{CO}_{2} \mathrm{e} / \mathrm{a}$ (Table 12).

h) Column 1: $11.63 € / \mathrm{Mg}$ compost (Bundesgütegemeinschaft Kompost 2017: 6) multiplied by the compost share of $18 \%$ for grass cuttings (Table 2), minus transportation costs for compost of $120,755 € /$ a (Table 10) divided by $81,361 \mathrm{Mg} \mathrm{FM/a}$ (Table 1). Columns 2 to 5: Multiplying the value from column 1 by $81,361 \mathrm{Mg}$ FM/a (Table 1).

i) Column 1: Table 16. Columns 2 to 5: Multiplying the value from column 1 by 81,361 Mg FM/a (Table 1).

j) Column 1: Table 13, i.e. the same as in the rural HTC scenario. Columns 2 and 4: Multiplying the value from column 1 by $81,361 \mathrm{Mg}$ FM/a (Table 1$)$.

k) Own calculation, based on equations (1), (3), (4), and (7), respectively.

1) Own calculation, based on equation (6).

Notes: Values rounded. - Not applicable. 
Table 23: Results of the Dynamic Investment Appraisal

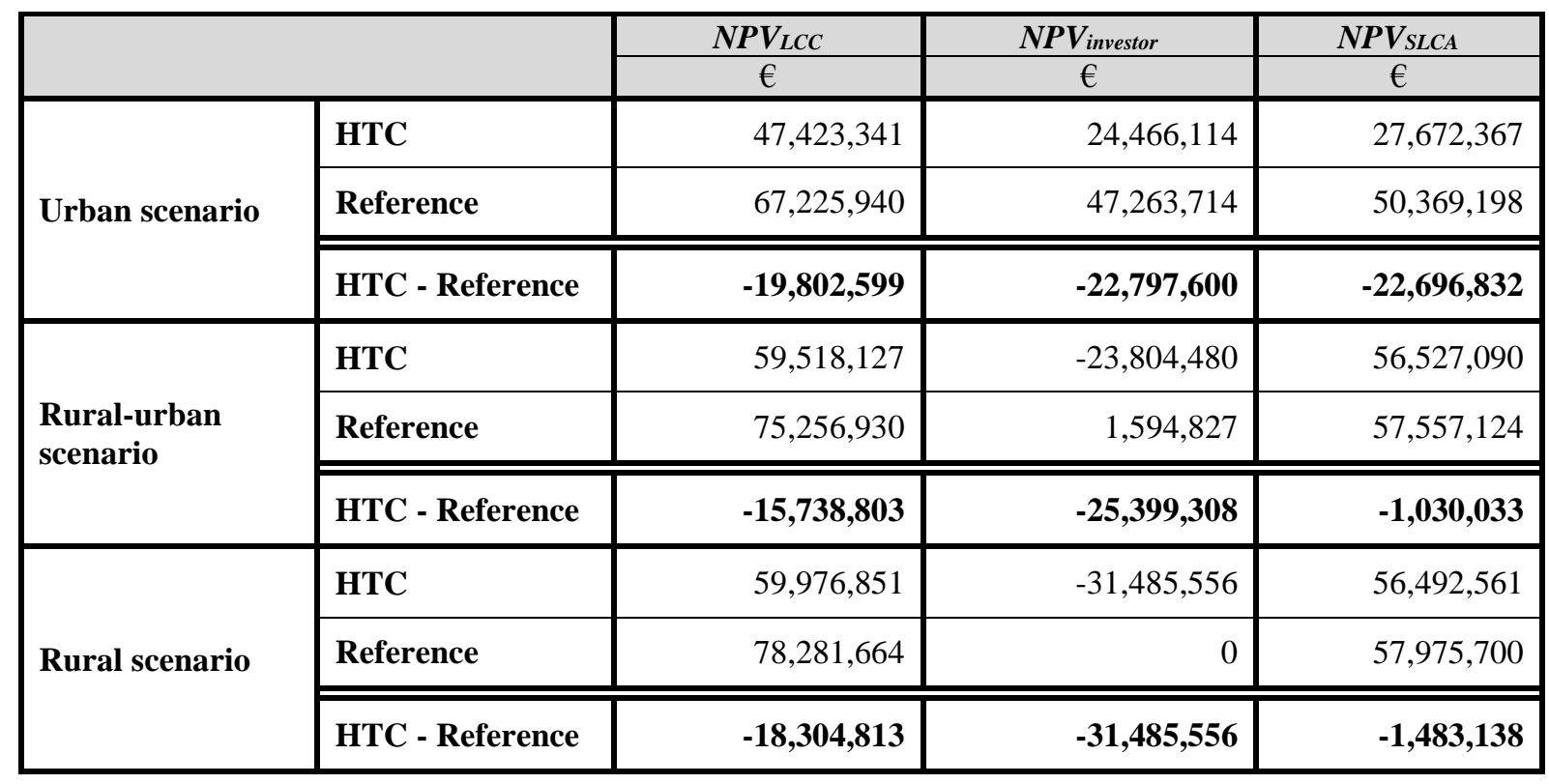

Sources: HTC and Reference: Tables 17 to 22. HTC - Reference: Own calculation.

Note: Values rounded.

Table 24: Carbon Abatement Costs

\begin{tabular}{|l|c|r|r|r|}
\hline & Unit & Urban scenario & \multicolumn{1}{c|}{$\begin{array}{c}\text { Rural-urban } \\
\text { scenario }\end{array}$} & Rural scenario \\
\hline$E_{H T C}{ }^{\mathrm{a}}$ & $\mathrm{Mg} \mathrm{CO}_{2} \mathrm{e} / \mathrm{a}$ & 3,844 & 3,878 & 4,517 \\
\hline$E_{\text {Reference }^{\mathrm{a}}}$ & $\mathrm{Mg} \mathrm{CO} 2 \mathrm{e} / \mathrm{a}$ & 26,074 & 26,410 & 30,266 \\
\hline Annuity $_{H T C} \mathrm{~b}$ & $€ / \mathrm{a}$ & $6,063,588$ & $5,702,360$ & $6,629,488$ \\
\hline Annuity $_{\text {Reference }}^{\mathrm{b}}$ & $€ / \mathrm{a}$ & $2,447,598$ & $4,031,640$ & $4,692,464$ \\
\hline \hline Abatement Costs $(\boldsymbol{A C})^{\mathbf{c}}$ & $\mathbf{\epsilon / M g ~ C O} \mathbf{M} \mathbf{e}$ & $\mathbf{1 6 2 . 7}$ & $\mathbf{7 4 . 1}$ & $\mathbf{7 5 . 2}$ \\
\hline
\end{tabular}

Sources:

a) Table 12 .

b) Tables 17 to 22 .

c) Own calculation, based on equation (5).

Note: Values rounded. 